\title{
THE PSYLHOLOGY OF PHE NEGRO
}

\section{by}

Erma Faltner, A.B., B.S. In Edacation i"

\section{SUBMITTED IN PAFIIAI FULFIIMENT OF THB REQUIREAENTS FOR IHE DEGREE OF \\ KASTER OF ARTS}

in the

GRADUATE SCHOOL

UNIVERSITY OF MISSOURI

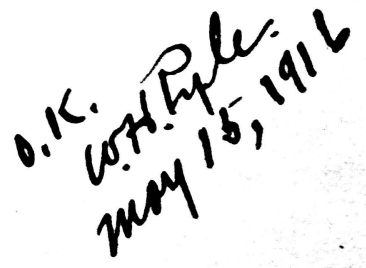


378.7971

$X W 172$

\section{CONTENTS}

Introduotion

Previous Strdies-_..

Growth in Power to Form Sensory-Hotor Co-ordinations---18

Social Considerations
Physical Ileasurements-

Summary-2.-

Appendix 


\section{INTRODUCTION}

Though the term "race psychology" has been in ase for some jears, the amount of scientific evidence of the existence of racial differences in mentality is very 8mall. In America, where 80 many races meet and contribate to the national life,there is a special need for accarate knowledge of ans racial differences that mag exist in mental capacity. in temperament,or in phraical derelopment. In the experimental study which is here reported, we have attempted to make some slight coptribation tp our knowledge of the physical development and mental capacity of negro children.

Fithout the adrice of Dr.W.H.Pyle, and the cooperation of Ur.J.E.HoPherson, superintendent of 8chools,Columb1a,Lfissourl, and Hr. Herbert Pryor,saperintendent of sohools, Hexico,H18souri, Mr.H.I.Cox, prinolpal of the Douglass school, and Miss Anna Pinley.prinolpal of the Jefferson sohool, this study would not hare been possible. 
PREVIOUS STUDIES

Because anthropology has found the physical measurements of the negro somewhat different from those of whites, and because soclology has found him in somewhat less farorable social development, unarranted generalizations regarding his inherent mental capacities have been made. To accept Bardin's* argument that the different physiology and anatomy of the negro brain will not allow him to assimilate the alien culture of the white race, or to conclude from Jordan's** persoral experience that according to the degree of whiteness of a negro, judged by his skin color, the more closely will he approach the white in mental alertness, or to take for granted the inferiority of negroes because Phillips*** found a greater school retardation of negroes than of whites is to assume much without the support of experimental data. Until the relation of inherent mental capacities with physical and social measurements is scientifically established, no accurate comparisons of the mentality of negroes and whites can be derived from the sources of anthropology and sociology.

*J. Bardin- The Pajohological Factor in the Southern Race Problem. Pop. Sc1. Ko. 1913: 83. 368-374.

**H. B. Jordan- The Blological and Sooial Worth of the Yalatto. Pop. So1. Mo. 1913; 83. 573-582.

***Byron A. Phillips- Retardation in the Elementary Schools of Philadelphia. Psychological Clinic, v.6, no.3. Vay 15,1912, p.79. 
The determination of the comparative scholastic efficiency of negroes and whites is the object of a study made by Mirion $J$. Hajo.* Scholastic efficiency was determired by the statistical treatment of school marks recelved by negroes and whites who were working under uniform conditions in the mixed high schools of New York City, and who were subjected to identical tuition and previous school preparation.

One hundred and fifty negroes were compared with an equal number of whites selected at random from the same classes as those represented by the negroes. When, through lack of the necessary records, such a selection of whites was impossible, white oases were selected at random from the current directory, care being taken to pair only those pupils who had been in school the same length of time. Several different nationalities, notably English, German, Irish, Italian, and Jowish, are represented in this study. The colored pupils represent "a closer selection Irom the entire population than do the whites at the ratio of about four to one. We do not know upon what basis this selection 18 made. It 18 probably upon a mixed basis of intellectual ability and social standing."

The average age of white pupils on entering high schools was 14 jears, 5 months, and of the colored children 15 jears, 2 months- a difference of nine months. The median age of whites

* Marion J. Nago- The Mental Capacity of the smerican Negro. Arohives of Peychology, no.28. November, 1913. 
at entrance was 14 jears, 6 months, and of negroes, 15 years, 1 month- a difference of seven months. The average deviation for whites was 9 morths and for nogroes was 15 months. In vien of the compulsory education law, and of no probable reason for a temporary discontinuance of school life at the close of the gramar school period, except in accidental cases, retardation in the grades seems the only likely explanation of the more than one-half year's advance in age of the negroes over the whites.

The average time spent in school when the records were taken was for 149 colored children 4.5 terms and for the 149 white ohildren 3.8 terms, which points to the conclusion that "for various reasons white pupils are more prone to quit the high school than are the colored."

"Relative rotardation and persistence in school would $800 m$ to be characteristio of the high school colored group. - - - - - - - - pupils of each group having entered high school at any time, when 50 per cent. of the colored pupils are still in attendance, only 28 per cent. of the whites will remain."

1s regards soholarship, with a passing mark of 60 , the median mark in all subjocts combined was for white pupils 66 . and for colored pupils 62, a difference of 4 points, or 4 per cont. 29 per cont. of the colored pupils reach or surpass the median mark for white pupils and 73 per cont. of the white Broup reach the median mark of the colored group. The average deriation for the white group is 7 , and for the negro group is 
6.5. The modian deviation probable error is 5.5 for the white group and 5 for the colored.

The colcred pupils make relatively the poorest showing in English and the commercial branches, and relatively the best in modern languages and in mathematics, especially arithmetic and algebra. Ancient languages, sciences, and history fall between these in the order named.

The percentage of colored pupils reaching the median mark of the white pupils is as follows:

Subject

Per cent.

English-first term.............................22

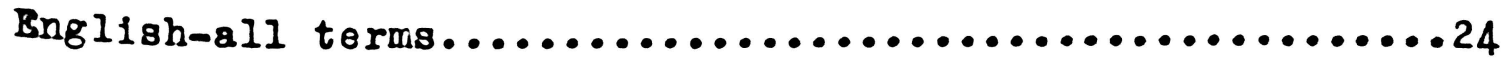

Lodern languages-pirst term.......................42

liodern. languages-all terms...........................

Nathemetics-pirst term..........................46

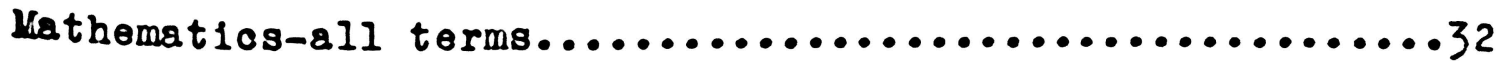

Solences-first term..............................39

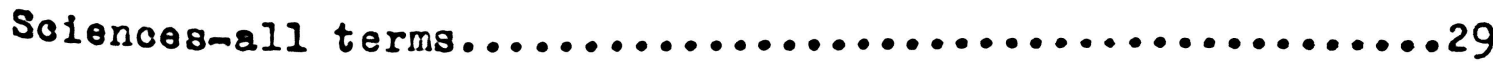

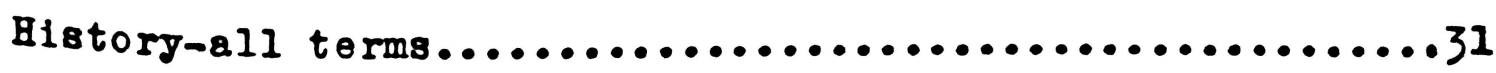

Anolent languages-all terms.......................27

Comercial branches-all terms.....................22

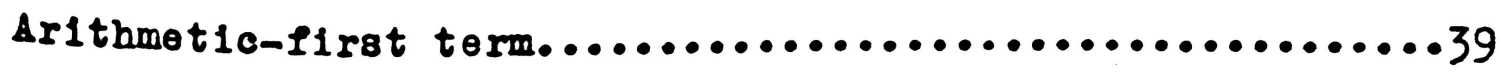

$\Delta 11$ subjects-all terms..........................29

The white pupils rank higher in every subject, but the namerical difference is not very great. 
The total number of subjects pursued was 2.433 for the White group and 1,855 for the colored group. The percentage of subjects passed on first trial was 76 for the white group and 58 for the colored. "Interpreting these figures as a measure of relative scholastic efficleney, the efficiency of colored pupils is 76 per cent. of that of the whites; that is, the colored pupils are about $3 / 4$ as efficient as the whites in the pursuit of high school studies."

As a study of high school grades, this study has contributed something of value to the study of the negro. The greatest chance for error, other than the uxcertainty always attendant upon a grading system, seems to 110 in the fact that "the general Impression among teachers is that colored pupils are less ouccessful in their studies than are the whites." In most subjects of study, the rariation between the white median and the negro median is but for points; and this impression, current among the teachers, might easily acoount for such a difforence.

The Binet-simon tests as revised by Dr. H. H. Goddard were Given by Alloe C. Strong* to 225 white children and 123 colored children in the sohools of Columbia. S. C. "Ilo marked rariation Irom the white ohlldren in manner of responding could be noted. - - - The replles were usually couched in fewer words than those of the white children. There was $108 \mathrm{~s}$ tendenoy to enter

* Josiah Uorge- 1 Comparison of thite and Colored Children by the Binet Soale of Intell1genoe. Pop. SCI. 10. Jan I914. 75 .

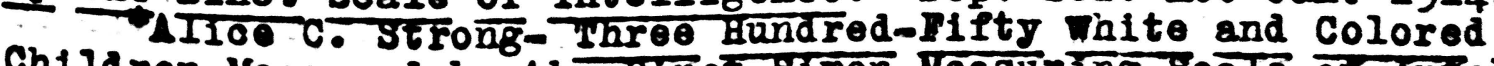
Chlldren Moasured by the BInet-SImon Heasuring Soale oI Intell- 
into conversation, and it was soon found that they were more at ease when reacting to the tests than whon an attempt was made to talk to tham about other things."

The groups were found to fall as follows:

Colored White

Por cent. Por cent.

Uore than one jear backward..................29.4 10.2

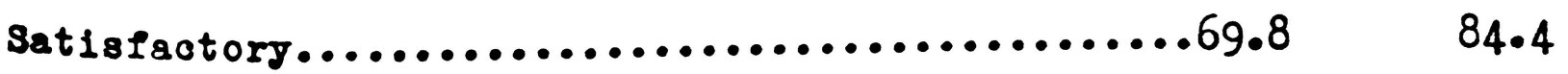

Yore than one jear accelerated....................8 5.3

"The picture tests gave the colored children considerable troublo, probably due to the difference in race esthetics. The tests relating to time and money, distinguishing between morning and afternoon, enumerating the months, counting stamps and making change, the drawing tests, both copying and reproducing from memory were all too difficult. The answers to the questions of comprehension, to the absurd statements and to the problems of varlous facts, were often absurd or senseless; the best replies, however, compare very favorabls with those of the white children, The definitions were often not better than terms of use, and frequently otated in the language of a jounger child."

"In general it may be said that the colored children excel In rote memory, 0.8. . In counting, repeating digits(but not one was ablo to repeat 26 syllables) naming words, making rhymes, and in time orientation, They are inferior to the whites,

1genoe: 1 Comparative Study. Pedagogical Suminary, v.20; no.4.

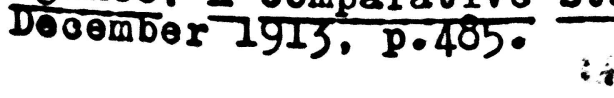


however, in esthetic judgment, observation, reasoning, motor control, logical memory, use of words, resistance to suggestion, and in orientation or adjustment to the institutions and complexities of oivilized society."

no what extent these differences are due to difference in raolal intellectual ability, and how much to onvironmental factors cannot be dogmatically stated."

The investigators think that they are certainly not due to sohool training as the colored school was in the city school system and its quality of teaching was good. "In order, therefore, to make the comparisons as just as possible, and at the same time ascertain the extent of the influence of environment, the white children were divided into two groups- city children and mill children. The economic, educational, and environmental conditions of the cotton-mill children are but little, if ang, better than those of the colored children. The results of the comparison showed that the proportion of colored children who are satisfactory is loss than that of the mill ohildren, which in turn is less than that of the city children. Less than 6 per cent. of the city childron aro more than a jear backward, 18 per cont. of the mill children, and 26 per cont. of the colored ohildren. Hone of either the mill or colored children test more than one year above age, while 10 per cent. of the city children do."

n-an_-.-the colored children make a better showing in the first five grades than in the first seven, but 
their inferiority to the whites existed throughout the school Joars, contrary to the widespread opinion that colored children are as well if not better endowed during the first school years. Again, according to the Binet scale, a larger number of white children are in a school grade below their mental ability than above, whereas the reverse is true of the colored children. A rough olassification into three groups, according to color- dark, modium, light-showed that the darkest children are the more nearIf normal, the lightest show the greatest variation, both above and bolow normal."

Uorse concludes that "negro children from six to twelve and possibly fifteen years are mentally different, and also jounger than the southern white children of corresponding ages, and that this condition is partially due, at least, to causes that are native or racial."

Byron A. Phillips*, finding in a former study that retardation in the Philadelphia schools increased in the different 8chools with the proportion of negro pupils in attondance, the greatest retardation being in colored schools, undertook a psjchological study of the matter and tested by the Binet scale 40 colored girls and 46 colored boys, totaling 86 , and 75 white girls and 62 white boys, totaling 137 . In pairing them of 80 that only those of comparable home conditions- excellent, good. fair, and poor- might be compared, the final comparison was made of 28 each of colored girls and white girls, and 29 each of colored boys and white bojs. In his comparison, he used

*Byron 4. Phillips- The Binet Tests Applied to Colored Children. Pgy.. Clinic v.8 no.7 December 15-1914, p.190. 
the actual individual retardation and acceleration in computing retardation and acceleration rather than grouping under year retardation acclention as is done in the south carolina study and by Goddard. Using this system, the investigator found the retardation for the white group to be 42.1 per cent. and for the colored group 68.4 per cont. with colored boys 17.4 per cent. more retarded than white bogs, colored giris 25 per cent. more than white girls; and the total rate of retardation of both Broups was 26.3 per cent.

For the whole group, regardless of home conditions, Phillips gives the following peroenteres: 59 per cent. of the colored bojs are retarded one jear or more and 21 per cent. of the white boje. 50 per cent. of the colored girls are retarded one year or more againgt 29.3 per cent. of the white girls, making a total colored retardation of 54.6 per cent. and a total white retardation of 25.4 per cent. 2 per cent. of colored boys are accelerated, against 21.9 per cent. of white bogs; 12.5 per cent. of colored girls against 18.6 per cent. of white girls. The total colored acceleration is 6.9 per cont. and the total white is 20.4 per cont.

The investigator concludes that, from pedagogical or psychologloal view points, the colored pupils are retarded from 20 to 30 por cont. more than the white pupils, that the white pupils are alwaye greatly above them in acceleration, and that the colored pupils as a class are good in the memory tests and poor in those requiring judgment. They were generally slower in response. The testing of colored children took a much longer time than that of white. Their reaction time was greater; they were less animated. 
The study reported by Josiah Morse and Alice C. Strong agrees with that made by Byron A. Phillips in finding the reaction time of neproes greater than that of whites, the negroes poor in tests requiring judgment and good in memory tests, except that the South Carolina study limits this excellence to rote memory and puts the negro down as poor in logical memory. Byron A. Phillips does not so differentiate.

Reduciñg Phillips' table so that it mag in some degree be comparable with that of the South Carolina study, we have:

$$
\text { Philadelphia Negro Cent. White }
$$

More than one jear retarded..........12.2 7.0

Satisfactory........................ $87 \cdot 7$

Accelerated more than ore jear.......00.0 12.7

South Carolina

Kore than one year retarded..........29.4 10.2

Satisfactory.....................69.8 84.4

1ccelerated more than one jear........... 5.3

In the comparison here, it must be kept in mind that the Philadelphia group is a solect one, having the individuals of the two groups paired as to home conditions. It is also a someWhat smaller group than that of the South Carolina study.

In paring indifiduals in regard to home conditions in the Philadelphia study. It would be of importance to know whether an excellent colored home was paired with an excellent white home on an absolute or a relative basis.

In measuring negroes and whites by the Binet tests, we obtain an interesting and a valuable comparison in terms of 
that scale. The Binet scale, however, involves a large element of acquired knowledge of the type that sociology calls social horedity.

Because the six year old negro child has been taught to say ovening instead of afternoon, confusion will arise when asked whether the time is afternoor or mornirig. Because the six Jear old white chlld answers correctly, he is scored on the question which has proved too difficalt for the negro, but which might have been answered had it been asked in terms common to the negroes' habitual phraseology. Again, it is hardly just that the nogro child should be marked mentally deficient because racial esthetics causes him to choose a standard of beauty other than that of the white. Though the Binet scale may point out differences between negroes andwhites, it may not be the best means of messuring mental capacities of negroes as compared with whites, for whom the scale was made.

The fact that, in the South Carolina study, the negro children did not enter readily into conversation with the investigator and that they seemed more at ease when reacting, causes some doubt as to the comparative emotional conditions of the negro Broup and of the white group when before the investigator.

A comparison of age retardations and accelerations in South Carolina reveals the fact that, while negro children are always more retarded than white children and while the retardation tends to increase in both races from age to age, the difference botweon negro and white retardation tends to decrease In the more advanoed ages. This would tend to show, as Morse points out, that the negro child is younger than the white child. 
It also seems to show that he tends to develop faster, thus overcomirg his hardicap. If this is true, it would be irteresting to leark whether this faster maturing would merely brirg the negro to adulthood faster than the white, leaving him behind the adult white in mental age, or whether this discreparcy in sental age may not be bridged.

A substitution test was given by Bird T. Baldwin* to 37 white Eirls and 30 colcred girls in the girls' division of the Pennsylvania reformatory. Fourteen other negro girls were too foeble mertally to porform the tests and three white girls failed to do 50 per cent. of the worin correctly. Practically all of the superior negroes of the school were included in the test. We know nothing of the mears of selecting the whites begond the lact that the tests were given metween $2: 45$ and $4: 30$ o'clock to five classes of girls who had not been in school during the morling." The whites averaged 16.7 joars of age, and the negroes 15.1 years, which gives the whites one year and alf's ereater age.

The negroes were"much slower to warm up to the occasion," and were the first to drop back and lose interest. They were more diffioult to arouse and could be atimulated only temporarilg through flattery. Their work was more irregular than that of the white girls and more dependant upon moods. Ther were eaplolous of the value of the task and carried it on with

Girla *Bird T. Baldwin- The Ioarning of Dolinquent Adolescent

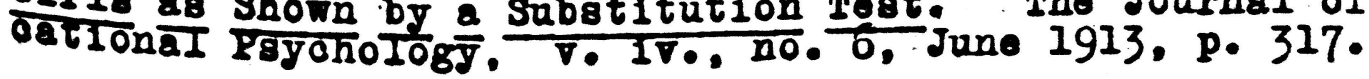


vacillatirg atterition. Thile partiellg occupied with the task at hand, they were also occupied in making random movements, mumbling, grumbling, humming, and saying origiral and funny things. They paid loss attention'to errors, were less accurate, and did not, as a rule, put as much effort into the work 28 the whites. There was little rivalry among the negroes though it was occasionally oncouraged.

The white girls averaged 72.3 substitutions and the negro 81rls 55.8. The negroes did 62.4 per cent. as much work as the white girls and made 245.3 per cent. as many errors. "The learning capacity of delinquent ${ }_{A}$ girls differs quantitatively and qualtatively from that of the white girls."

The age difference between the two groups could not have accounted for the great divergency in efficiency between the two groups. This study is of value as showing the efficiency attained by negroes and whites urder the given circumstances, but because of the fact that the negroes did not feel the importance of the work and were not interested to the same degree 28 the whites, it would be valuable to have further proof that the lack of interest was due to irability on the part of the nogroes tested.

The object of a recent study at the University of Missouri* was to establish norms for the various mental abilities for negro school children and to compare these norms with similar norms established for white school ohildren. Tests in logical memory. rote memory, substitution, word-building, cancellation, controlled

Oniversity of Regadale- Psychology of the Negro- Thesis, 1914. 
association, Irte association, imagination, and permenent retention were given in the white schools of columbia. Hissouri, and In the colored schools of Columbia, Wissouri; Wexico, knd lioberly. Missouri. The following tebles give the results of the investlgetion in terms of $p \in r$ cent. difference between the races and sexes:

\section{Racial Differences}

\begin{tabular}{|c|c|c|c|c|}
\hline & & & & \\
\hline & Thite & Negro & hite & Negro \\
\hline $\begin{array}{l}\text { Iogical Hemory Immediate } \\
\text { Iogical Hemory Permanent } \\
\text { Rote Memory } \\
\text { Substitution } \\
\text { Controlled Asoociation } \\
\text { Proe Associction } \\
\text { Mord-Bullding } \\
\text { Uancellation }\end{array}$ & $\begin{array}{r}21.1 \\
13.7 \\
43.9 \\
111.9 \\
180.8 \\
23.1 \\
98.2 \\
1.6\end{array}$ & & $\begin{array}{r}27.1 \\
25.8 \\
31.8 \\
118.1 \\
124.3 \\
18.0 \\
127.3\end{array}$ & 8.2 \\
\hline
\end{tabular}

Sex Differenceg

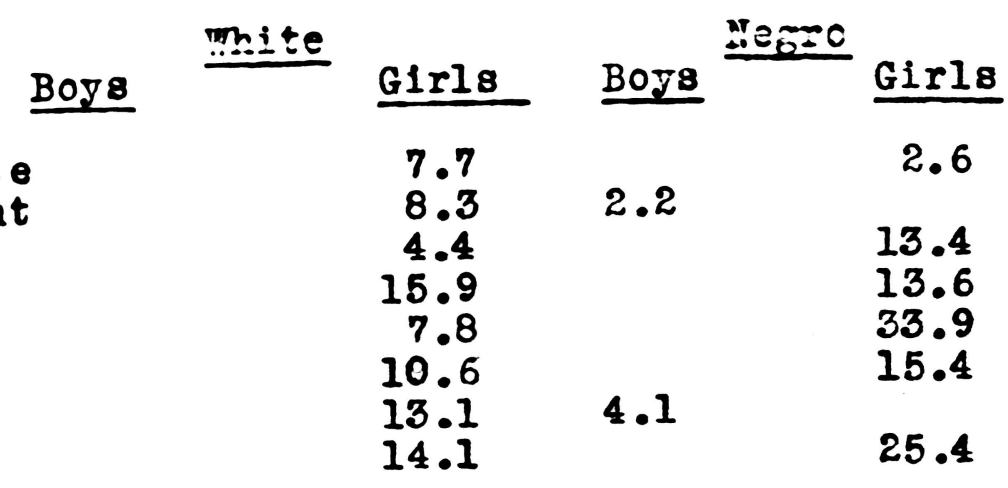

Iogical Lemory Immediate

Iogloal Lemory Permanent

Rot o Hemory

Substitution

Controlled Assoolation

Free Association

Tord-Bullaing

Cancellet ion

In the inkblot test, whites and negroes, boys end giris,

Wore practically enal, the white bojs averaging 6.3, negro

boys 6.6. white girls 7.0, negro girls 6:9.

The negroes and whites cre then more nearly equal in the

inkblot and cancelletion tests, and the greatest inequality is

found in controlled association, substitution, and word- 
bailding. The negroes have a much better memory for concrete then for abstract rords, but are inferior to the whites in both. In the sixth grades of the Douglass School (colored) and of the Jefferson School (white) both of Columbia, Missouri, two subotitution learning experiments were given for four practice per10ds. 'She following table shows the per cent. gain between the test 8 :

Per Cent. BOYS

gain from

practice

\section{$1-2$}

$2-3$

$3-4$

AT.

$1-4$
Digit-Symbol

Thite Nerro

$23.6 \quad 51.0$

$0.7 \quad 3.7$

$7.4 \quad 27.2$

$\begin{array}{ll}10.6 & 27.3 \\ 33.8 & 99.3\end{array}$
Symbol-Digit

White Negro

$3.1 \quad 35.0$

$34.3 \quad 22.8$

$32.6 \quad 19.0$

$20.0 \quad 25.6$

$83.7 \quad 97.1$

\section{GIRIS}

\begin{tabular}{lllll} 
& Thite Negro & Thite & Iegro \\
$1-2$ & 30.9 & 61.5 & 26.2 & 29.7 \\
$2-3$ & 12.2 & -1.5 & 18.3 & 22.3 \\
$3-4$ & 17.3 & 22.5 & 18.8 & 16.5 \\
$3-4$ & 20.1 & 27.6 & 21.1 & 22.8 \\
\hline AT. & 72.3 & 95.1 & 76.9 & 84.8
\end{tabular}

18 The table shows that the percentage improvement for negroes 18 mach greater than for whites. This seems to point to the conolusion thet the whites learn more rapidly than the ne שroes and approach the limit of their improvement more rapidis than do the negroes.

A classification into groups coming from good homes and from noor homes was made of the purils of a wite sirth grade exa of all the papils of the Douglass Sohool (oolored), and the - Iflolenoles of the groung were then compared. "Then the class of negroes having the best environmentel conditions is chosen, 
the negro boys have about four-fifths as great mental ability as the average of the white boys, and the negro girls have about three-fourths as great mental ability as the average of the white girls. Difference in social position has the greatest effect on tests requiring quickness ir learning, quickness In making associations where specific associations are required, both immediate and permanent memory for ideas, and constructive Imagination. Among negro children of the botter social class, the tendeney to approach the mental ability of the white children with increasirg age is more marked."

$\Delta$ study of muscular speed and of muscular strength was made In the Douglass School(colored) and the Jefferson School (white) of Columbia, Missouri with the result that but slight difference was found between white boys and black boys in either strength or speed, though negro bojs were found to be somewhat more ambidexterougingeed. After ten jears of age, negro girls tended to become stronger than white girls, and white girls to have a higher tapping rate than negro girls. The negro girls wereslightly more ambidexterous in both strength and tapping. The negroes, both boge and girls, were slightly more variable, the reverse of whioh is true in the mental tests.

"In general, the average of the negroes has about two-thirds Or 1088 mental ability than the average of the whites. -manthe negro girls approaoh the white girls in mental ability a little more closely than the negro boya approach the white boys. Negro bojo and negro girls are farther apart in mental ability than white boys and girls, and in both races the girls are superior. 
With an increasing age there is a tendence for the difference between whites and regroes to become less, the tenàcrey is more marked with boys than with girls. About ore-fifth of the negroes are equal or superior to the average of the whites and about three-fourths of the whites are equal or superior to the average of the negroes."

"In tests requiring quickness of learning and forming new associations, quickness in forming old associations, where an essociation of specific kird and not just any association is required, and in tests of constructive literary imagination or the ability to combine seomingly urrelated and contradictory impressions into a connected and meaningful whole, the negroes are less than half as successful as the whites." Among other things of value that this study reveals, it will be noticed that the same tendeney to diminish with age the difference between negroes and whites is found here in the use of mental tests as was found in the Binet study of South Caroline negroes. 
II

GROMTH IN POMFR TO FORH SFISORY-IOTOR COORDINATIONS

Part I. The Develorment with sge of the Leaming vanacity of Negro Chllaren.

The object of this study was to determine the quickness and accuracy with which negro and white school children form sensory-motor coordinetions.

To accomplish this purfose, Epparat us devised by Dr. T. H. Pyle was used. id diggram on the following page shows sometining of the construction of the apraratus. In the box (a) at the left are $24 \mathrm{big}$ and 24 little marbles; in the middle box (b) Fitrin -

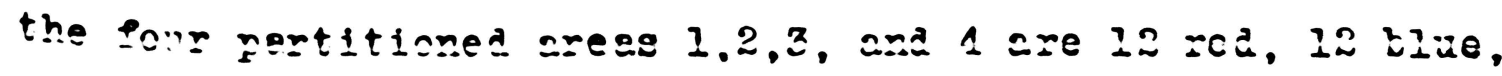
12 mixed, and 12 bleck marbles; in the box at the right (c5) are 48 cards, each one of which calls for two marbles--one from the left box $(a)$ and one from the midale box (b). The subject sits bofore the $t a b l e$, drews a card from (c5), crops it into (c6), takes the two marbles called for by the card from boxes (a) and (b)-one marble in each hand--and disposes of them in the holes in the top of the table. Ilttle marbles go in the hole (d) to the left; big marbles $g c$ in thc second hole from the left (e); black marbles go in the hole $(g)$ close to the subject; red, blue, and mixed marbles go in the hole $(\hat{b})$ close to the midale box. If a red marble 18 called for by the card, the subject is to press dom on tho left pedal $(h)$ ander the table with the left foot; if a mixed marble is called for, the aubiect is to press down the right pedal (1) with the right loot. Black marbles put into hole (g) will be delivered into box ( $\mathrm{g}$ ); red marbles put into hole $(f)$ with the pressure of the left pedal $(h)$ will be delivered into box $(k)$ : 


\section{IEARNIITG APPARATUS}

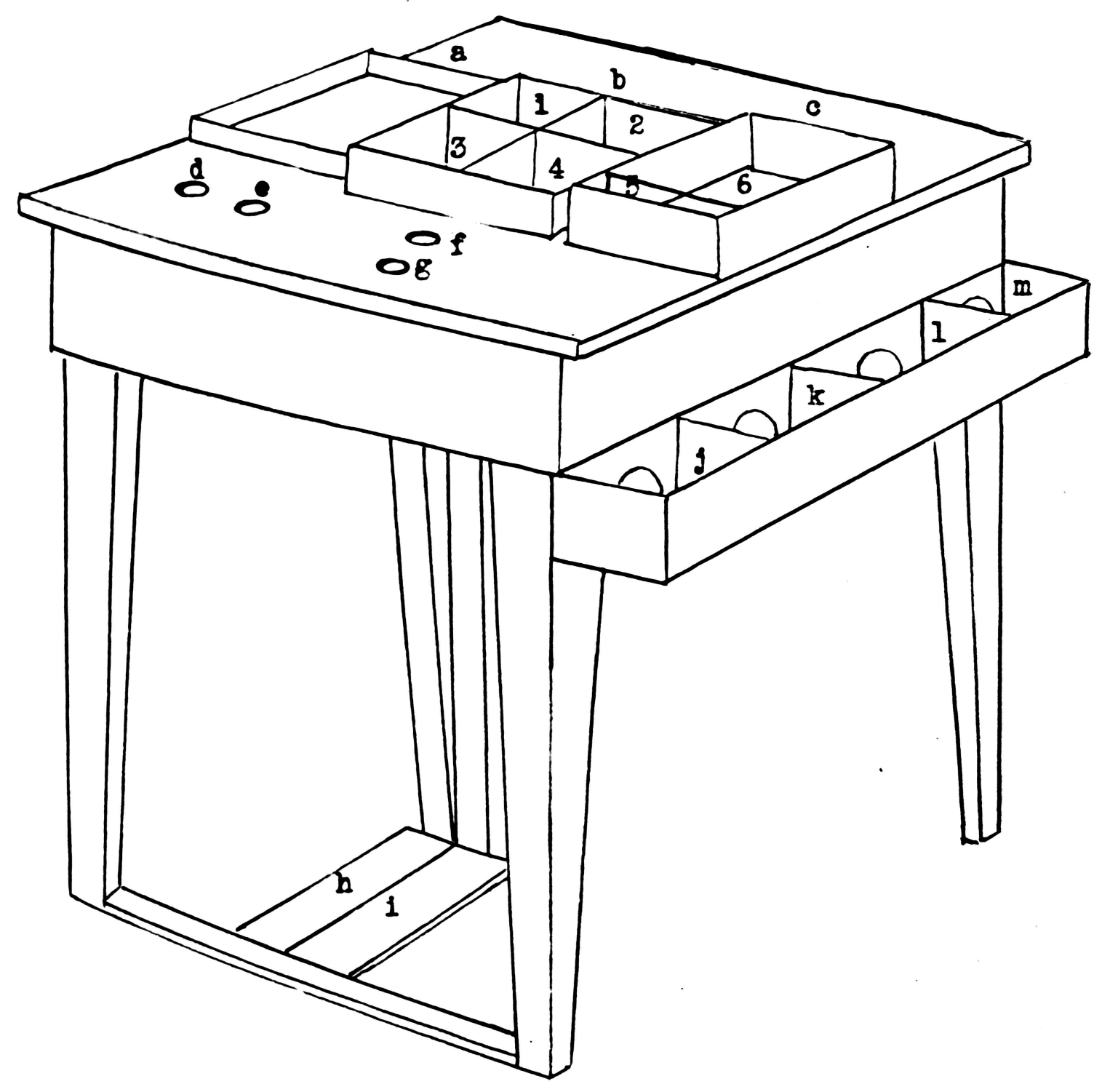


mixed marbles put into hole (f) with the pressure of the right pedal (1) will be delivered into box (1); blue marbles pat into hole $(f)$ will be delivered into box $(m)$; big marbles and little marbles pit into holes (e) and (d) respeotively will be delirered into a partitioned box which is situated just ander the holes. Any deriation in the process will cause tine marble dropped to be delivered into some comartment other than its proper one. Finding a marble out of place when the test is finished constitutes an error. Speed end accuracy are the measures of effiol enoy in the performance.

No previous training othur than the ablity to read six 8 imple mords--Big; Iittle, Blue, Black, Red, and Mixed,-is necessary. The test involves the reaction to a new situation; the grasping of many details; a large el ement of memory. attention, end concentration; the ability to keep many operations going at once; the elimination of unnecessary movements; and the building up of a new set of habits.

The tests were given to 106 negro girls and 71 negro boys of the Douglass School (negro--seren grade elementary school and throe year high sohooll and 112 white girls, and 76 white boys of the Jefferson School (white--seren grede elementary 8chool). No ohild ander the fourth grade was tested. This oolection should give a negro group somewhat older than the white group and a negro group that would contain a greater proportion of superior thirteen, fourteen, and fifteen year old students in the high school group. The sunerior thirteen, fourteon, and fifteen jear old children of the white group would 
also be in high school and no white high school students were tested.

The method adopted was such that each individual anderotood thoroughly what was expected of him before he began work. Bach subject was given minate instructions, was allowed to watch two other subjects perform, and was allowed to dispose of one marble of each kind to make sure that the instructions Tere properly anderstood. The subject was encouraged to ask questions and answers were given oren as to the construction of the apparatus. The importance of both speed and accuracy was emphasized. Two trials at disposing of the marbles were given to each subject and the record in timo, errors, and marbles correctls placed per minate was recorded. The two tests for each ind ividual took from fifteen to twenty-fire minutes according to ti:e quickness with which the individual somprehended the nature of the test and the rapidity with which he executed it. The conditions ander which the work wes carried on were very satisfactory. In each school a seperate room was given over to tre work and the interest and co-operation of the teachers induoed an exoellent attitude towerd the teot. In aro asing the interest and efforts of the subjects, the test was decidedy suocessful. Several subjects expressed their desire to own a similar piece of apparatus and examined the table for the purpose of constructing one. At noon, it was not uncommon for pupils to retarn and ask to be allowed to do the experiment again. There was no und ue nerrousness on the part of the sabjects except in the case of a fer of the negro girls of the high school 


\section{DISTRIBUTION CURVES}

$\operatorname{Numb}_{40} \rightarrow \mathrm{r}$

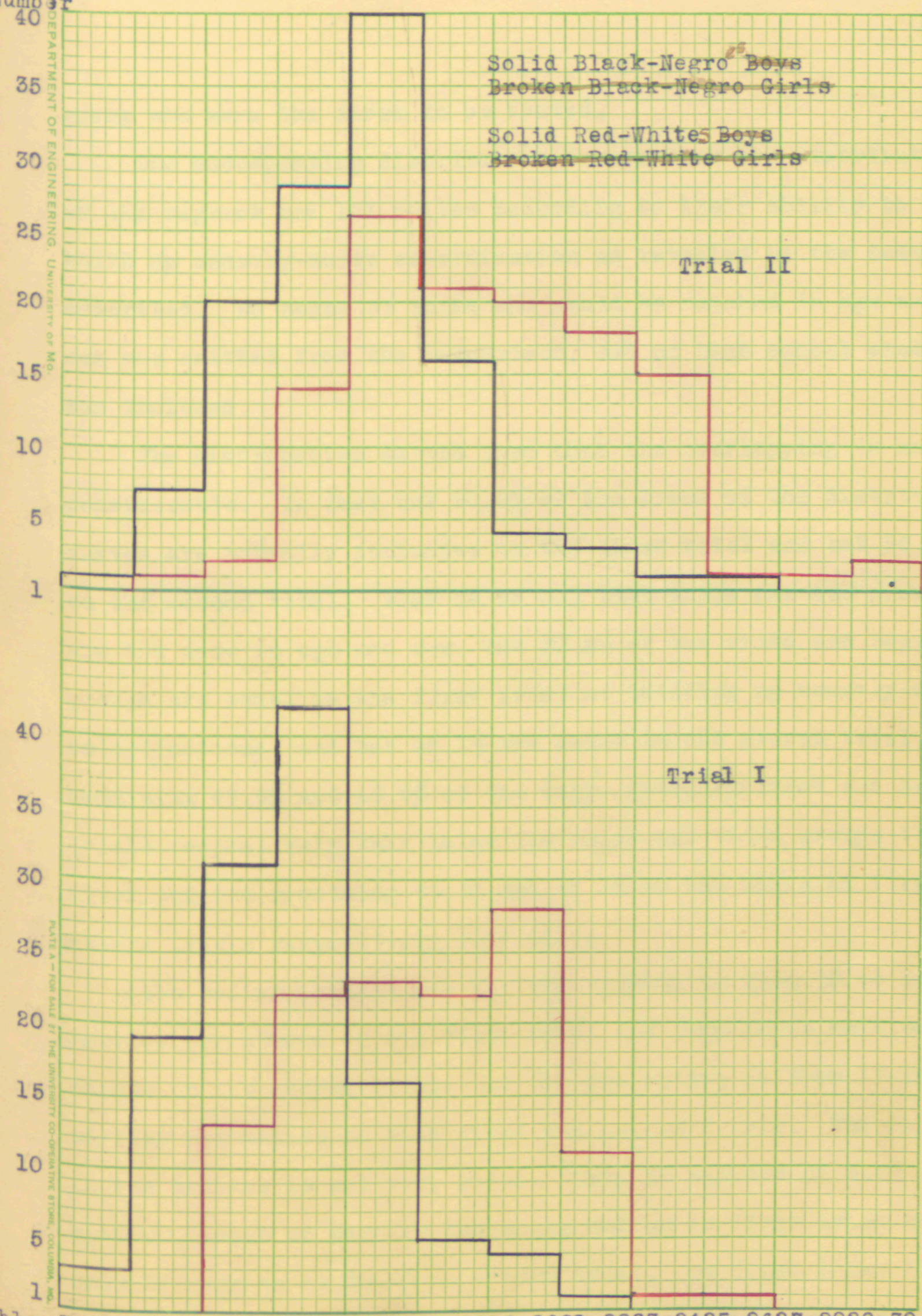

$\begin{array}{lll}\text { Larbles } 7-8 & 9-10 & 11-1213-1415-1617-1819-2021-2223-2425-2627-2829-30 \\ \text { per minite }\end{array}$ 
Group who were the first to be tested.

The accompenjing distribation curves shor the distribution of 121 negroes and 121 whites acoording to their ability to balld up sensory-motor co-ordination as rerealed by the test desoribed. Ho negro or wite who could be matched in age and sex Wes omitted from the comperison, and no high school student was inoluded.

The distribation ourves oh ow that the overlapping is not considerable. In fact bat $50.4 \%$ of the areas of the distribation ourres are mataelly inolusire on the first trial and bat $56.1 \%$ on the second trial. That is to saj that while the two groups are the seme in age and sex, bat $50.4 \%$ of the white and negro Broups are equal on the first trial at ballding up sensorg-motor oo-ordinations, and but $56.1 \%$ are equal on the second trial. The remaining $49.6 \%$ and $43.9 \%$ of the negro group. on first and second trials respectively. fall belor the negro and white growg that are - qual, and the remaining $49.6 \%$ and $43.9 \%$ of the white, on first and second trials respectively. fall abore.

The modian performance for the negroes is from 13 to 14 marbles per minute on the firet trial and from 15-16 marbles per minate on the seoond $t$ rial, and for the whites is from 17-18 marbles per minute on both first and second trials. The difference In the medians 18 not very great. Only 10 negroes or $8.2 \%$ horrerer, reach or sarpass the white median on first trial and only 25 negroes or $20.6 \%$ on second trial. On first trial 109 Whites or $90.0 \%$ reach or surpess the negro median, and on second trial 104 whites or $85.9 \%$ reach or surpass the negro median. 
It secms then that the whites far outolass the negroes in the rapidity and acouracy wh thich sensory-motor co-ordinations are formed. The difference betreen the races seems slightly les8 on the second performance than on the first as the overlapning $185.7 \%$ great or on the second then on the first performance. This indicates that the negroes improved more from the first to the second trial than did the whites.

If we compare negroes and whites of the same age, we find the whites superior to the negroes at erery age. This is shown in the following table.

\section{Arerage number of marbles correotly placed per minate.}

Trial I.

White Girlo

AgO HO. Of ceges AV.NO.Marbles A.D. GA.D. P.B. KP.E.

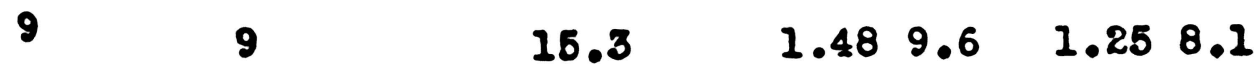

10

21

14.9

2.2415 .01 .8912 .7

11

20

17.2

$2.3013 .3 \quad 1.94 \quad 11.3$

12

19

16.0

$\begin{array}{llll}2.70 & 16.8 & 2.28 & 14.2\end{array}$

13

28

18.8

$2.71 \quad 14.8 \quad 2.2912 .5$

14

$$
9
$$

18.3

2.8515 .5

2.4013 .1

15

16

17

$$
8
$$

19.6

$\begin{array}{llll}1.53 & 7.8 & 1.29 & 6.5\end{array}$

2

16.5

$\begin{array}{llll}3.50 & 21.2 & 2.95 & 17.9\end{array}$

1

22.0

Average

Irom

$9-16$

17.0

$2.25 \quad 13.2 \quad 1.90 \quad 11.1$ 


\section{Trial II}

\section{White Girlo}

AgO No.01 Cases Av.NO.Marbles A.D. FA.D. P.E. KP.E. \% Improvement

$\begin{array}{llllllll}9 & 9 & 17.0 & 1.78 & 10.4 & 1.50 & 8.8 & \text { Prom Trial I-II } \\ 10 & 21 & 16.7 & 2.24 & 13.4 & 1.89 & 11.3 & 12.0 \\ 11 & 20 & 19.3 & 3.05 & 15.8 & 2.57 & 13.3 & 12.2 \\ 12 & 19 & 18.1 & 2.73 & 15.0 & 2.30 & 12.6 & 13.1 \\ 13 & 28 & 20.6 & 2.87 & 13.9 & 2.42 & 11.7 & 13.1 \\ 14 & 9 & 21.1 & 2.80 & 13.2 & 2.36 & 11.2 & 15.3 \\ 15 & 3 & 20.3 & 1.10 & 5.4 & .924 .6 & 3.5 \\ 16 & 2 & 20.0 & 2.00 & 10.0 & 1.69 & 8.4 & 21.2 \\ 17 & 1 & 24.0 & & & & & 9.0 \\ \begin{array}{l}\text { Arorage } \\ \text { from }\end{array} & & & & & & & \end{array}$

\section{Trial I}

Negro Girls

AgO 110.01 Cases AT.HO.Marbled A.D. \%A.D. P.B. GP.B.

9

10

11

12

13

14

15

16

17

18 Arerage erom

5

9

15

9

18

18

16

9

6
12.4

11.4

12.4

12.7

13.3

13.8

14.4

15.1

13.3

15.0 $\begin{array}{llllll}12.9 & 1.95 & 15.1 & 1.65 & 12.7\end{array}$

$\begin{array}{llll}1.68 & 13.5 \quad 1.42 \quad 11.4\end{array}$

$2.0417 .9 \quad 1.7215 .1$

$\begin{array}{llll}1.89 & 15.2 & 1.59 & 12.8\end{array}$

$\begin{array}{llll}1.58 & 12.4 & 1.33 & 10.5\end{array}$

$2.32 \quad 17.4 \quad 1.9614 .7$

$2.3717 .1 \quad 2.00 \quad 14.5$

$1.8312 .7 \quad 1.5410 .7$

$2.56 \quad 16.92 .16 \quad 14.3$

$2.56 \quad 18.2 \quad 2.16 \quad 16.2$ 


\section{Irial II}

\section{Iegro Girlo}

Ag* No.01 Cases AT.No.Marbles A.D. \$A.D. P.E. \%P.L. \& Improrement From Triel I-II

$\begin{array}{lllllllr}9 & 5 & 12.6 & 1.52 & 12.0 & 1.28 & 10.1 & 1.6 \\ 10 & 9 & 12.8 & 2.09 & 16.3 & 1.76 & 13.8 & 12.2 \\ 11 & 15 & 14.2 & 2.25 & 15.8 & 1.90 & 13.3 & 14.5 \\ 12 & 9 & 13.7 & 1.88 & 13.7 & 1.58 & 11.5 & 7.8 \\ 13 & 18 & 15.2 & 2.16 & 16.2 & 1.82 & 12.0 & 14.2 \\ 14 & 18 & 15.7 & 1.90 & 12.1 & 1.60 & 10.2 & 13.7 \\ 15 & 16 & 17.7 & 2.83 & 15.9 & 2.39 & 13.5 & 22.8 \\ 16 & 9 & 17.3 & 2.58 & 14.3 & 2.18 & 12.6 & 14.5 \\ 17 & 6 & 16.5 & 2.83 & 17.1 & 2.39 & 14.4 & 24.0 \\ 18 & 1 & 14.0 & & & & & -6.6 \\ \begin{array}{l}\text { Arerage } \\ \text { 190m }\end{array} & & 14.5 & 2.09 & 14.3 & 1.76 & 12.0 & 12.7\end{array}$

\section{Trial I}

mite Borg

AgO IJo.of Cages ir.Ho.Marbles A.D. FaA.D. P.B. jö.B.

9

10

11

12

13

14

15

3

16.0

14.1

16.1

16.0

17.5

15.3

18.7

$2.66 \quad 16.6 \quad 2.24 \quad 14.0$

$\begin{array}{llll}.92 & 6.5 & .77 & 5.5\end{array}$

$2.42 \quad 15.0 \quad 2.04 \quad 12.7$

$2.50 \quad 15.6 \quad 2.11 \quad 13.2$

14

9

7

1

1

20.0

21.0

$\begin{array}{llll}1.85 & 10.5 \quad 1.56 & 8.9\end{array}$

$\begin{array}{llll}2.87 & 18.7 & 2.42 \quad 15.8\end{array}$

$\begin{array}{llll}2.70 & 14.4 & 2.28 & 12.2\end{array}$

18 


\section{Trial II}

\section{White Borg}

Age No.01 Cases AT.110.Uarbles A.D. GA.D. P.E. GP... \% Improvement

9

10

11

12

13

14

15

\section{6}

18

Arerage

Irom

9-16

$$
3
$$

17.6

$\begin{array}{llll}2.20 & 12.5 & 1.85 & 10.5\end{array}$

15.5

18.0

16.1

19.2

17.5

20.1

18.0

25.0

$\begin{array}{llll}1.42 & 9.1 & 1.20 & 7.7\end{array}$

$2.60 \quad 14.4 \quad 2.19 \quad 12.2$

$2.73 \quad 15.0 \quad 2.3012 .7$

$2.71 \quad 14.1 \quad 2.29 \quad 11.9$

$\begin{array}{lllll}2.83 & 16.1 & 2.39 & 13.7\end{array}$

$4.01 \quad 14.1 \quad 3.88 \quad 16.8$

From Trial I-II

10.0

9.9

11.8

13.1 .

9.2

14.3

7.4

$-10.0$

19.0

18.0

$2.64 \quad 13.6 \quad 2.23 \quad 12.3$

11.1

\section{Trial I}

Negro Boys

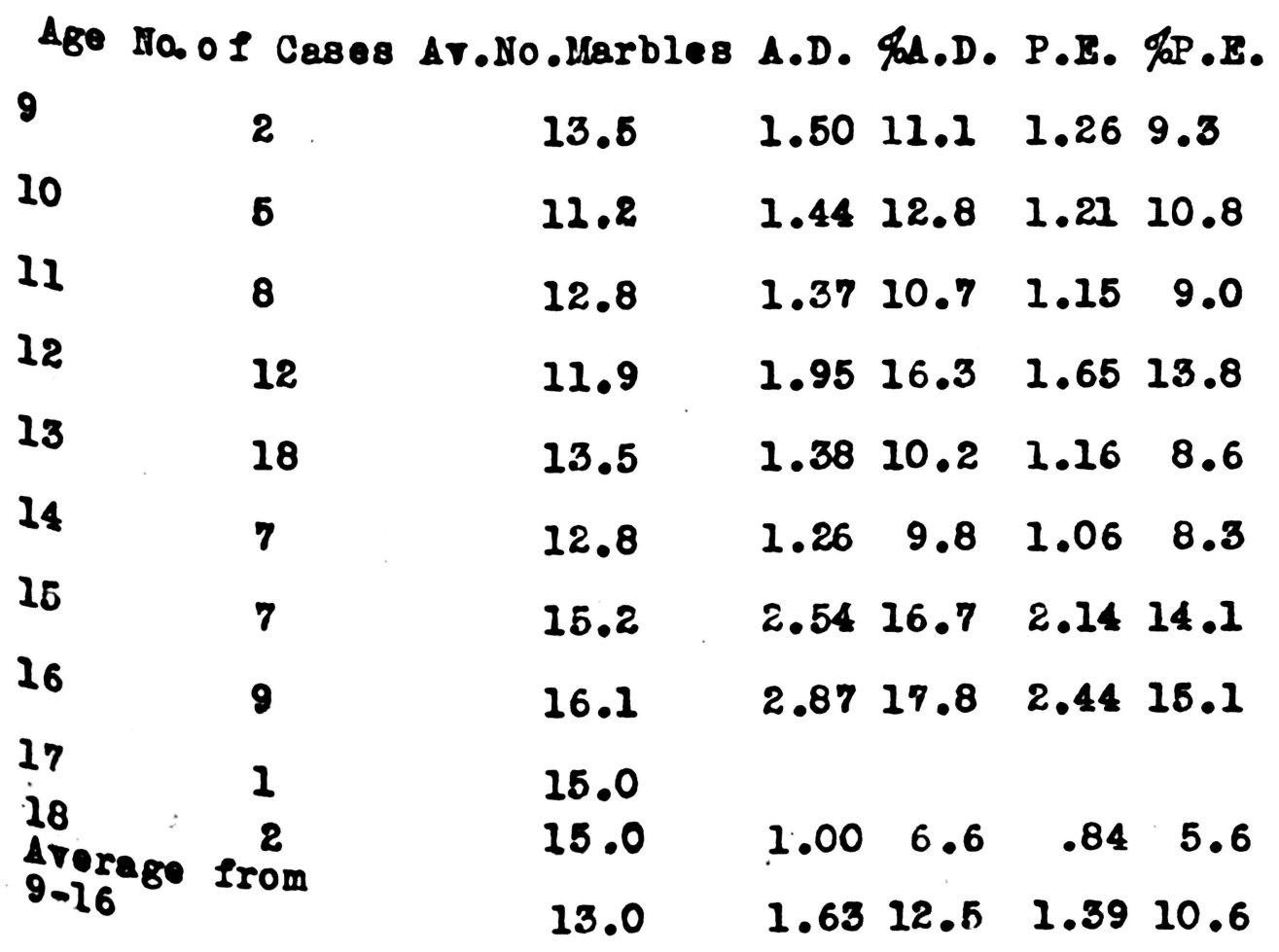


Trial II

Negro Boys

Ag0 10.01 Cases AT.No.ltarbles A.D. \%A.D. P.S. FP.S. \% Improvement

\begin{tabular}{|c|c|c|c|c|c|c|c|}
\hline 9 & 2 & 14.5 & 3.50 & 24.1 & 2.95 & 20.4 & From $\underset{7.4}{\operatorname{Tr} 18]}$ \\
\hline 10 & 5 & 13.8 & 1.16 & 8.4 & 1.00 & 7.2 & 23.2 \\
\hline 11 & 8 & 14.6 & 1.62 & 11.0 & 1.36 & 9.3 & 14.0 \\
\hline 12 & 12 & 13.4 & 1.95 & 14.5 & 1.64 & 12.3 & 12.6 \\
\hline 13 & 18 & 15.8 & 1.68 & 10.6 & 1.42 & 8.9 & 17.0 \\
\hline 14 & 7 & 15.7 & 1.10 & 7.0 & .92 & 5.9 & 23.4 \\
\hline 15 & 7 & 16.5 & 2.50 & 15.1 & 2.11 & 12.8 & 8.5 \\
\hline 16 & 9 & 20.0 & 1.55 & 7.7 & 1.31 & 6.5 & 24.2 \\
\hline 17 & 1 & 18.0 & & & & & 20.0 \\
\hline 18 & 2 & 19.0 & 0.00 & 00.00 & 0.00 & 00.00 & 26.6 \\
\hline $\begin{array}{l}\text { Aro } \\
\text { Pro } \\
9-1\end{array}$ & & 14.9 & 1.93 & 12.9 & 1.62 & 10.8 & 14.6 \\
\hline
\end{tabular}

In comput ing arerages, ages 16, 17, 18 are not inoluded because of the very small namber of cases.

The superiortty for each ege is shown belor.

Superiority of:

White girls orer!

nogro girlo.

IrIal I

$$
\text { Ag0! } 9: 10: 11: 12: 13: 14: 15 \text { ! }
$$

Irial II

$$
\begin{aligned}
& 24.1 ! 29.4 ! 38.7 ! 25.9 ! 36.8 ! 31.8 ! 36.1 ! \\
& 34.9 ! 30.4 ! 35.9 ! 321 . ! 35.5 ! 34.3 ! 14.6 !
\end{aligned}
$$


FFICIENCY CURVES

Trial I

Solia B1 rak-Negro Boys

Broken Black-Negro Girls

Solid Red-White Boys

Broken Red-White Girls

larbies per

Minute

20

19

18

17

16

15

$3--1$

14

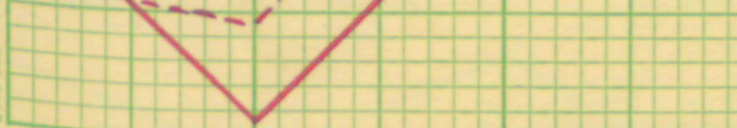

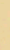

13

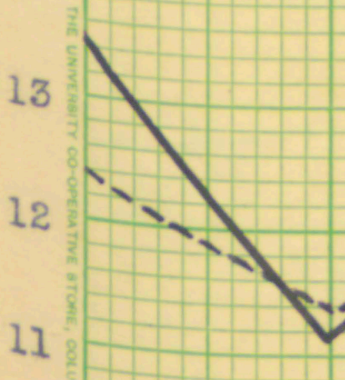

10

Age 9

10

11

12

13

14 


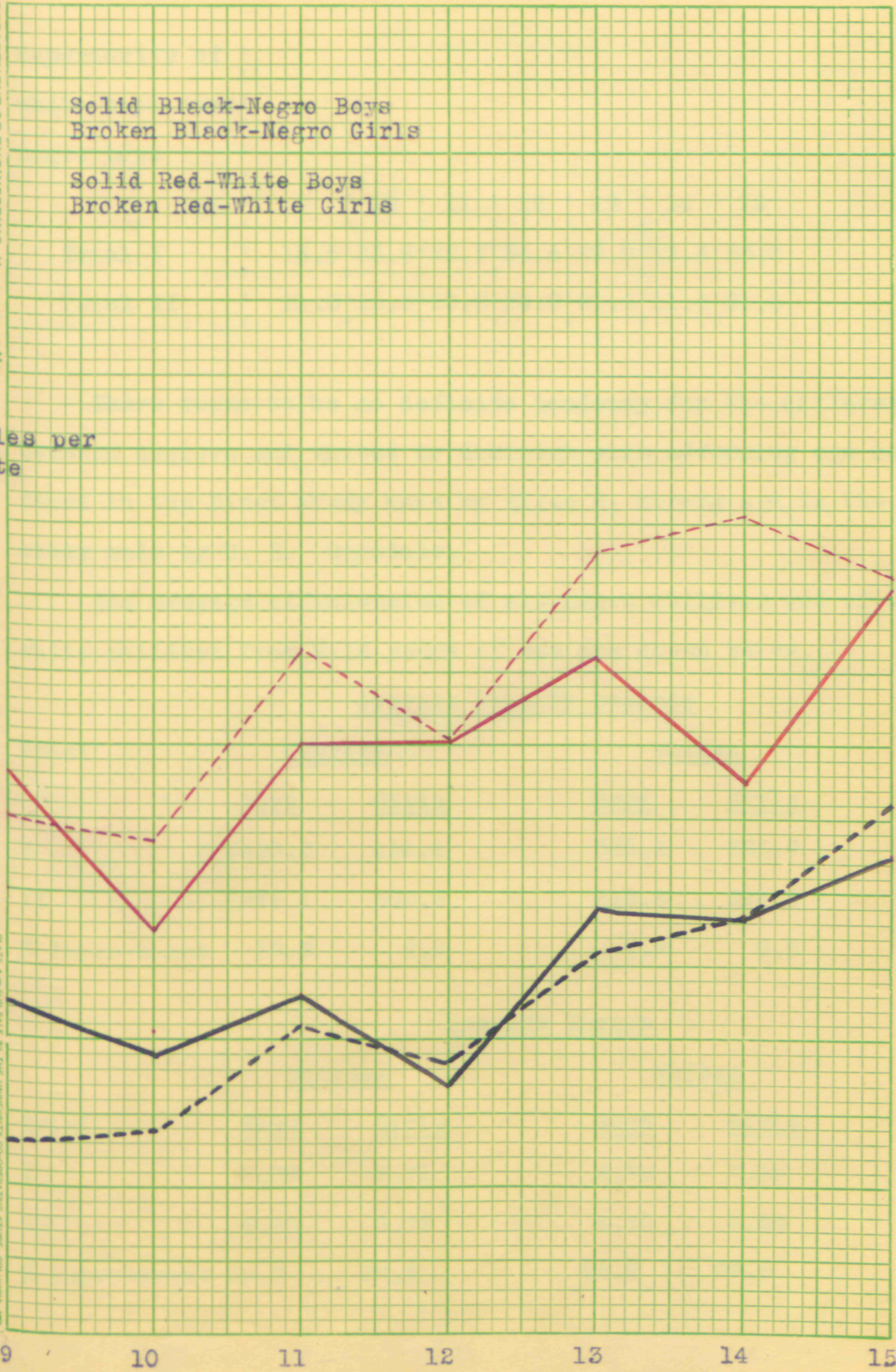

Marbles per Minute

21

20

19

18

17

16

15

14

13

12

11

10

Age 9

10

11

12

13

14 


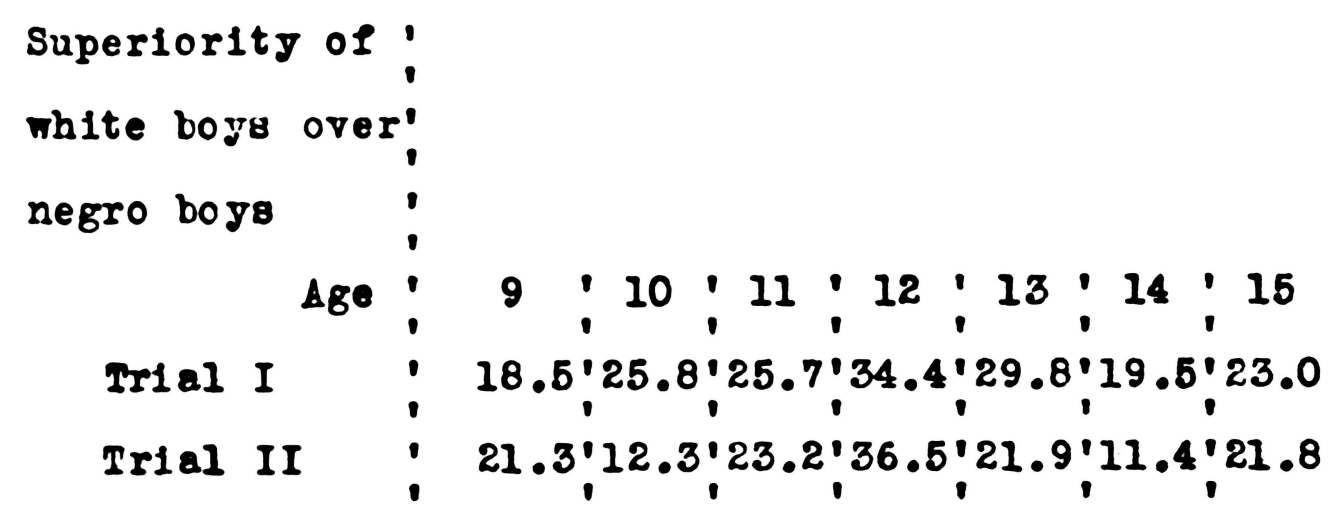

There seems to be no definite tendenoy for the differences between negroes and whites to diminish with advanoing age as wes found in the Blnet studs mad o by Al10e C. Strong and in the otudy made by C. E. Rag8dalo.

The arerago efflolencies of all negro ohildren and of all white children from 9-16 years of age are shown belor.

\section{Average time in seconds}

Trial

Negroes

Whites

\begin{tabular}{|c|c|c|c|c|c|}
\hline & Borg & Girlo & & Borrs & Girlo \\
\hline$T$ & 428.3 & 414.4 & & 339.6 & 326.7 \\
\hline II & 376.1 & 380.3 & r & 312.8 & 298.8 \\
\hline 6 Improvement & 12.2 & 8.2 & & 7.9 & 8.5 \\
\hline
\end{tabular}

\section{Average Brrors}

Negroes

Trial

Boys Girlo

I

II

8.07

9.71

4.98

5.79

38.5
Whites

Bors Girls

$6.70 \quad 7.46$

$4.70 \quad 4.65$

$26.8 \quad 37.6$ 
NET RF ICIENCI ES

Marbles correctly placed per minute.

Negroes

TRIAI

I

TI

\% Improveme nt
Bo78 Girls

$13.00 \quad 12.91$

$14.90 \quad 14.55$

14.6

12.7

Whites

Negroes are slower and somewhat more inaccurate than whites on both first and second trials. Negro bojs are slower and more accurate on flrst trial and faster and more accurate on second trial thon are negro girls. White girls are faster and less accurate on first trial and faster and more accurate on second trial than are white boys. The sex differenoes in net efficlenoy are comparatively 8mall. White girls being $5.1 \%$ better on first trial than white boys and $5.5 \%$ better on second trial, and negro boys being $0.6 \%$ better then negro girls on first trial and $2.4 \%$ better on seoond trial. Ragsdale found the girls of both races superior to the boys. The peroentage superiority according to race is given belor.

Per cent. Spperiority

Boys Megroes

I Timo

II Time

I Errors

II Errors

llet Effiolenos

Not Efficienos

\begin{tabular}{|c|c|c|c|}
\hline & Degroes & Whites Negroes & Whites \\
\hline I & Time & 20.7 & 21.1 \\
\hline II & Time & 16.8 & 21.4 \\
\hline I & Errors & 16.9 & 23.1 \\
\hline II & Errors & 4.8 & 19.5 \\
\hline & Efficienoy I & 24.9 & 32.2 \\
\hline & Efficienoy II & 20.8 & 30.6 \\
\hline
\end{tabular}


Though it is generally thought by employers of negroes in domest io service and industrial occapations, that the negro Is a comparatively fast and careless worker, the evidence here Indicates that the negroes approach the whites more olosely in acouraoy thm in speed. In administering the test, it was noticeable that both negroes and whites were much more interested in the numer of mistakes made than in the time reouired for the performance although the instructions stressed both equally. It may be that the number of mistakes impressed the children as a more tangiable measure than the time of performance. The above table shows clearly that negro bojs approach white bojs more closely than negro girls approach white girls, which does not gree fith the recults of Ragsdale's study.

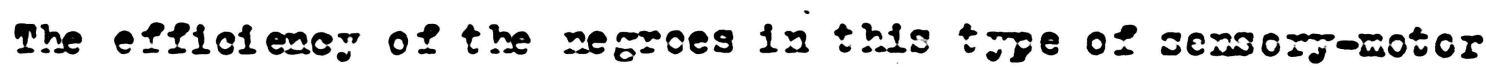
co-ordination 18 for the first trial about $71.5 \%$ that of the whites, and for the second trial about $74.3 \%$ that of the whites. It will be remembercd that the Mayo study of scholarship in the New York schools found the negroes $76 \%$ as efficient as the whites and Ragsdale's stady found them to be about two-thirds as effiolent. The efflolemy table shows most clearly what has been shom In all the tables, namely thet the percentage improvement for negroes is somewhat greater than for whites. This agrees with the results of Ragsdale's contl med learning test, and saggests that the white is the nuicker learner of the two, sterting better than the negro and reaching his maximal efflolenoy earlier, and that though the negro may IInally attain the same efflciency as the white, the efflolenog mast come through a slower process. 
This woild mean that the white can acquire a skill or complete a task of lesrning end tarn his energies to another field while the negro must continue at the task first undertaken. Such an ? hereditary difference between the two races would have a great offect upon the development and the ultimate attainment of the two races.

Part II. The Ultimate Canacity of Negro Children in Complex Sensory-Motor Coordinations.

In view of aoguiring further experiment al evidence. on this point. three white and three negro boys, and three white and three nepro girls were given tris same test for builaing ap sensorymotor co-ordinations. The experiment was continued for nineteen days with praotice periods of twenty-five minutes each day. The principal of the Douglass School was asked to select the negro chlldren to be tested and no qualification was mentioned other than that they be abcut thirteen jears of age, that they rould be interested in the test, and that he considered the boys and girls comparable with each other. Thirteen years was the age selected as more of the children tested, both white and negro, were of that age. These negroes were matched with whites of the same age, of same sex, and of elther absolute equality in the sensory-motor test or of relative equality in reference to their relation to tielr age and sex norms. Wherever possible a learner of the seme type was ohosen--thet is if a negro's attainment had depended on speed, or on acouracy, or on both, an attempt wes made to select a white of the same type. This was to discount variations due to individuel differences as far as possible. 
The following table shows the results of the matching.

\begin{tabular}{|c|c|c|c|c|c|c|}
\hline Case & Subject & Grade & $\begin{array}{l}\text { Home } \\
\text { Cond1t I ons }\end{array}$ & $\begin{array}{l}\text { Rank in } \\
\text { Scholarship }\end{array}$ & $\begin{array}{l}\text { Rank in } \\
\text { previous } \\
\text { test. }\end{array}$ & $\begin{array}{l}\text { Absolute or } \\
\text { relative } \\
\text { match. }\end{array}$ \\
\hline I & $\begin{array}{ll}l & \text { b.g. } \\
l & \text { T.g. }\end{array}$ & 7 & $\begin{array}{l}\text { Yodf um } \\
\text { poor }\end{array}$ & best & best & $\Delta t$ \\
\hline II & $\begin{array}{ll}2 & \text { b.g. } \\
2 & \pi \cdot g \text {. }\end{array}$ & 7 & $\begin{array}{l}\text { good } \\
\text { poor }\end{array}$ & best & & R- \\
\hline III & $\begin{array}{ll}3 & \text { b.g. } \\
3 & \text { m.g. }\end{array}$ & $1 h_{5} 8$ & $\begin{array}{l}\text { good } \\
\text { poor }\end{array}$ & & worst & $\Lambda$ \\
\hline IV & $\begin{array}{ll}1 & \text { b.b. } \\
l & \text { w.b. }\end{array}$ & $1 \mathrm{h.8.}$ & $\begin{array}{l}\operatorname{med} 1 \mathrm{um} \\
\text { meds am }\end{array}$ & & & $\mathbf{R}$ \\
\hline$\nabla$ & $\begin{array}{ll}2 & \text { b.b. } \\
2 & \text { n.b. }\end{array}$ & $\begin{array}{l}6 \\
4\end{array}$ & $\begin{array}{l}\text { good } \\
\text { poor }\end{array}$ & best & $\begin{array}{l}\text { worst } \\
\text { worst }\end{array}$ & $\Delta t$ \\
\hline$\nabla I$ & $\begin{array}{ll}3 & \text { b.b. } \\
3 & \text { w.b. }\end{array}$ & $\begin{array}{l}6 \\
5\end{array}$ & $\begin{array}{l}\text { good } \\
\text { medif um }\end{array}$ & & worst & Rt \\
\hline
\end{tabular}

The reoord of home conditions comes from the teachers'

reports. The scholarship ranking also comes from their reports of the fire best and the five worst pupils in each grade. The ranking of best and worst in the test comes from the selection of the best and rorst $20 \%$ for each age.

The negro group has a greater sohool adrancement and, rotively speaking, superior stending in scholarship, and better ranking in the previous tests, and relatively or perhaps actually better home conditions as some proportion of the school population of the Jefferson Sohool are the children of shoe factory workers. 
Marblas per

Minite

64

$\ln _{x \rightarrow 1}$

54

44

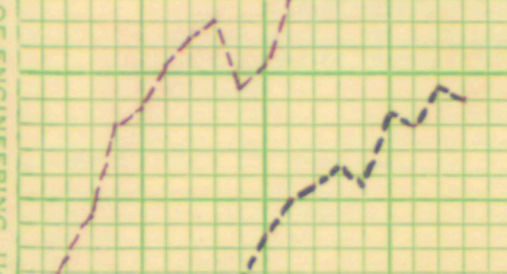

34

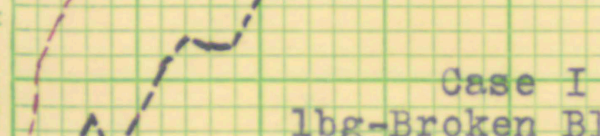

24.

$\begin{array}{ll}i{ }^{\prime} v^{\prime} & \text { Ibg-Broken Black } \\ i^{\prime} & \text { Iwg-Broken Rea }\end{array}$

24

í

14

64

54

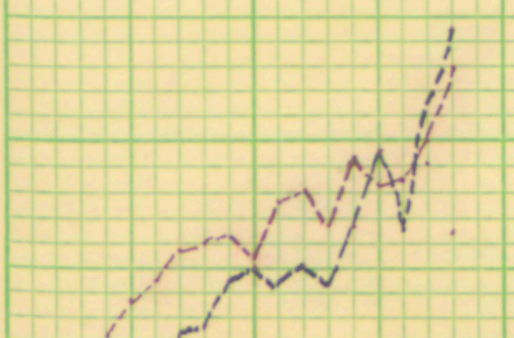

44

34

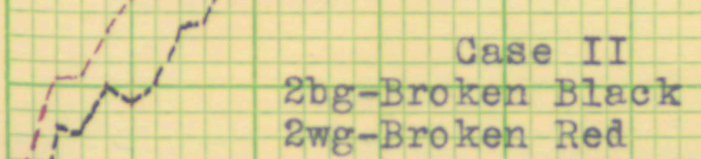

24

in 2wg-Broken Red

14

64

54

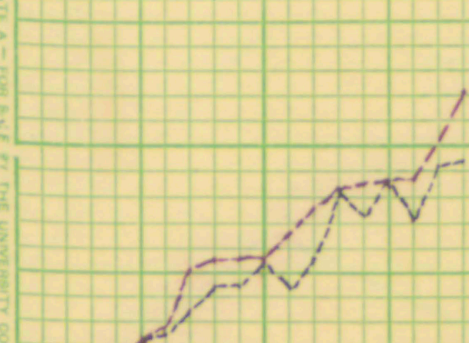

44

34

3bg-Broken BIEck

3wg-Broken Red

Days
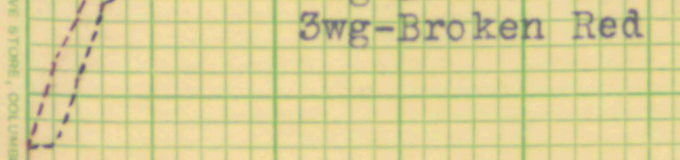

1

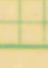

$$
\begin{array}{llll}
6 & 11 & 16 & 21
\end{array}
$$

16

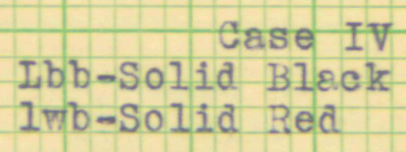


lirbles per Minute

53

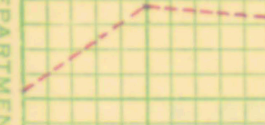

48

43

38

53

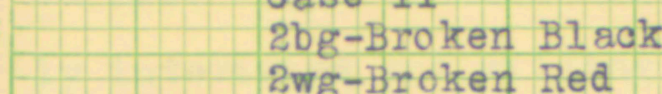

48

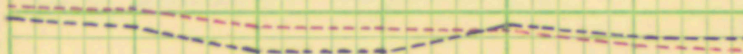

43

38

53

48

43

ractises

Pract 45

46

Case III

3bg-Broken Ble ak 3wg-Broken Red

Case I

lbg-Broken Black

lwg-Broken Red

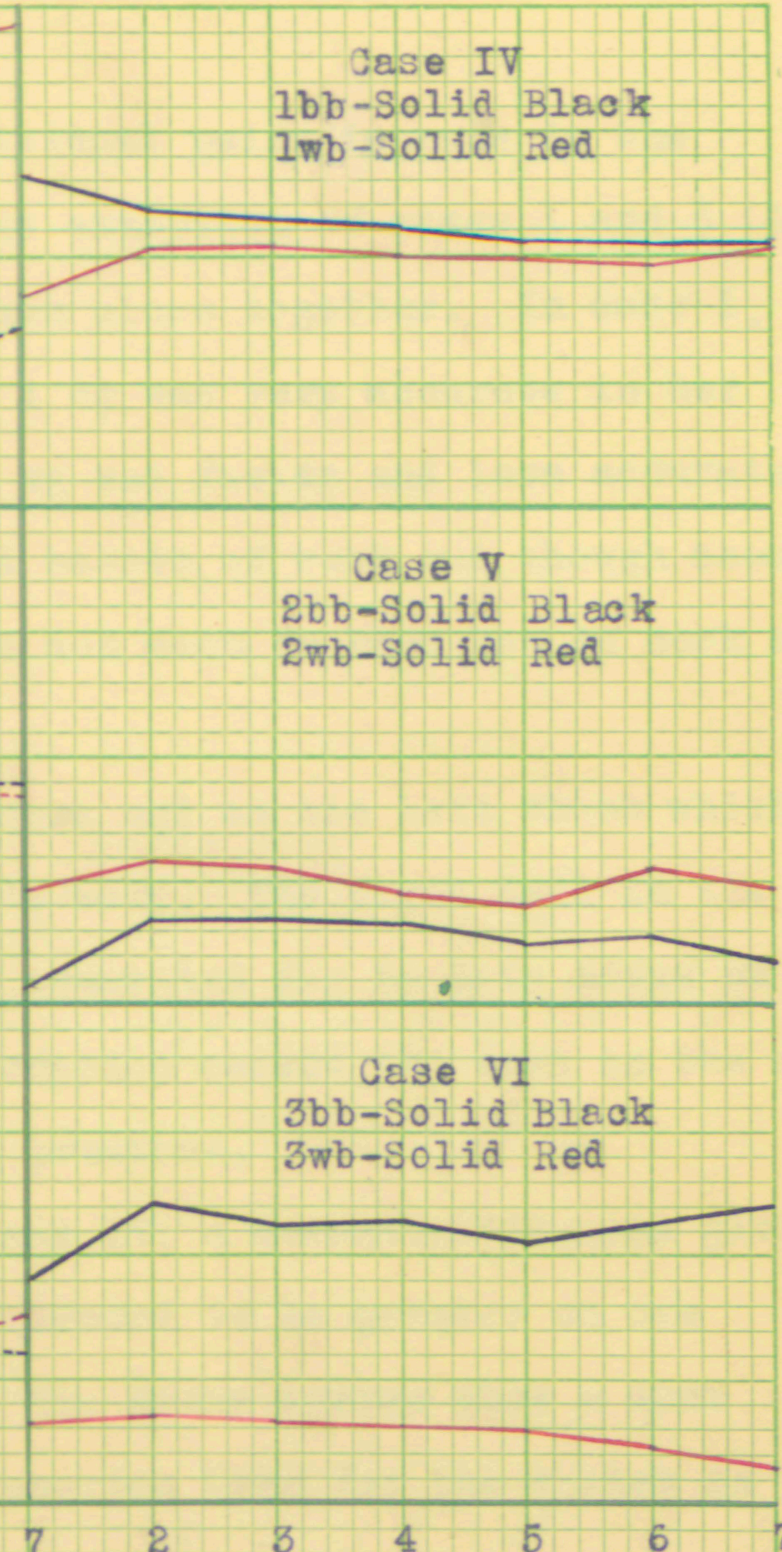

47
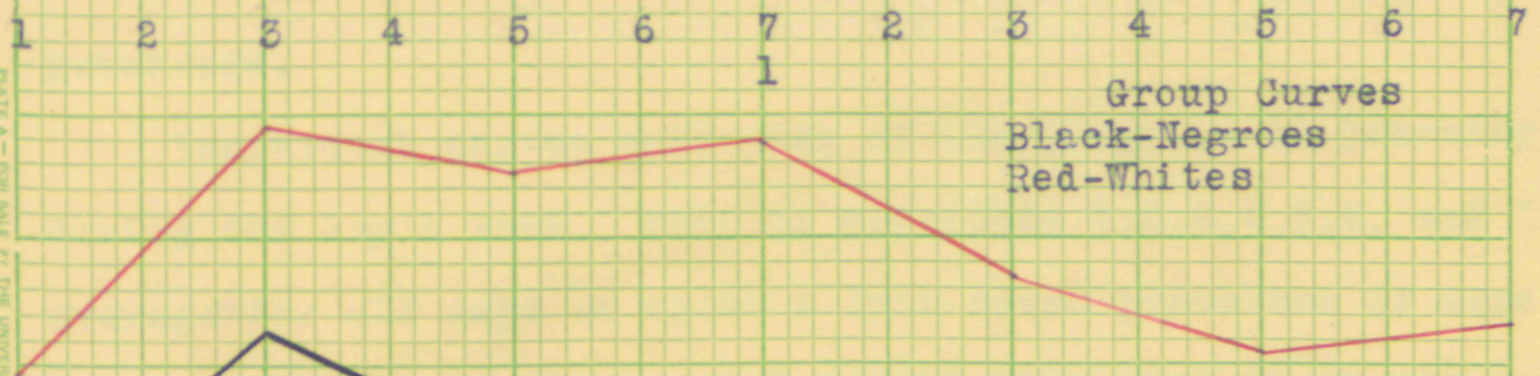
A comparison of the individual pairs is mede in the accompanying owres. With the exception of cases 1 and 6 ( $1 \mathrm{bg}-$ 178 and $3 \mathrm{bb}-3 \mathrm{wb})$ the carves ran 01080 together. In case 1 , the mat oh was not perfect as 1 bg was very acourate in her two preliminary $t$ rials and 1 mg was faster and less acourate. In case 6,3rb formed very bad habits of work and though seemingIf interested and wiling did not eeem to kncm hor to rork at bis sallest capacity.

In case 4. Imb had a serere out on his left thamb which interfered with his lost day's work. The first fall in tho carres of $1 \mathrm{bg}$ and $\mathrm{Lbg}$ can be accounted for by lo te hours on the preceeding night. Interruption cansed the drop in the curves of 1 Ing and $2 \pi b$ on the tenth prectioe.

Before practice daj8 3 and 17 , a demonstration each individual. The effeot seemed to be greater on the negroes than on the whites. The group carves show a more deoided improvement for the negroes then for the whites on these praot 1008.

Individual carves were rade of the progress of learning during the doy's work. That is practices $1,2,3,4,5,6$, and 7 were averagdfor all days on which a fall seven practices or more were at tained. The individual curves show that there are negroes and whites, slow and quiok learners, represented by the seme type of ourve. A omblnation of carres into race group curves seem to show no striking differenoes. *The demonstration consisted merelg of the observeris foing
through the experiment once for the benefit of the abfiect. 
The table from whioh these curves are made is given belor.

$\begin{array}{lccccccc}\text { Negroes } & 1 & 2 & 3 & 4 & 5 & 6 & 7 \\ 2 \text { bg } & 44.15 & 44.70 & 44.63 & 44.06 & 43.82 & 43.73 & 45.26 \\ 2 \text { bg } & 47.83 & 47.49 & 46.54 & 46.41 & 47.65 & 47.03 & 46.99 \\ 3 \text { bg } & 45.58 & 45.33 & 45.78 & 45.44 & 44.45 & 44.35 & 44.07 \\ 1 \text { bb } & 51.22 & 49.97 & 49.43 & 49.15 & 48.64 & 48.55 & 48.63 \\ 2 \text { bb } & 38.79 & 41.67 & 41.47 & 41.29 & 40.56 & 40.92 & 39.83 \\ 3 \text { bb } & 47.18 & 50.10 & 49.28 & 49.54 & 48.56 & 49.34 & 50.01 \\ \text { arerage } & 45.79 & 46.64 & 46.18 & 45.98 & 45.61 & 45.65 & 45.79\end{array}$

$\begin{array}{lllllllll}\text { Whites } & 1 & 2 & 3 & 4 & 5 & 6 & 7 & \text { Prsctice }\end{array}$

Iwg $\quad 53.3656 .8956 .2757 .6856 .4256 .4357 .36$

2Wg $\quad 48.1048 .0447 .4147 .4347 .3646 .8246 .43$

3WJ 46.9746 .0346 .8247 .4646 .3644 .3145 .81

IWb $\quad 46.5248 .2948 .2548 .0547 .9647 .8748 .23$

2wib $\quad 42.72 \quad 43.92 \quad 43.6242 .56 \quad 42.0543 .4842 .84$

3int 41.1241 .5641 .2641 .1540 .9840 .3939 .66

average $46.46 \quad 47.45 \quad 47.27 \quad 47.3946 .85 \quad 46.56 \quad 46.72$

Taking the group averages for the dally practices, the whites start 1.76 of a marble per minate better than the negroes and beep the lead unt1l preotice dag 16, where theg are .1 of a marble poorer than the negroes and practice 18, where there is a difference of 1.64 marbles in faror of the negroes. On the last day's practice the whites are .68 of a marble better then the negroes.

Unfortanatelg it was imposeible to toke the group to the 
(For Nineteen Days Practice)

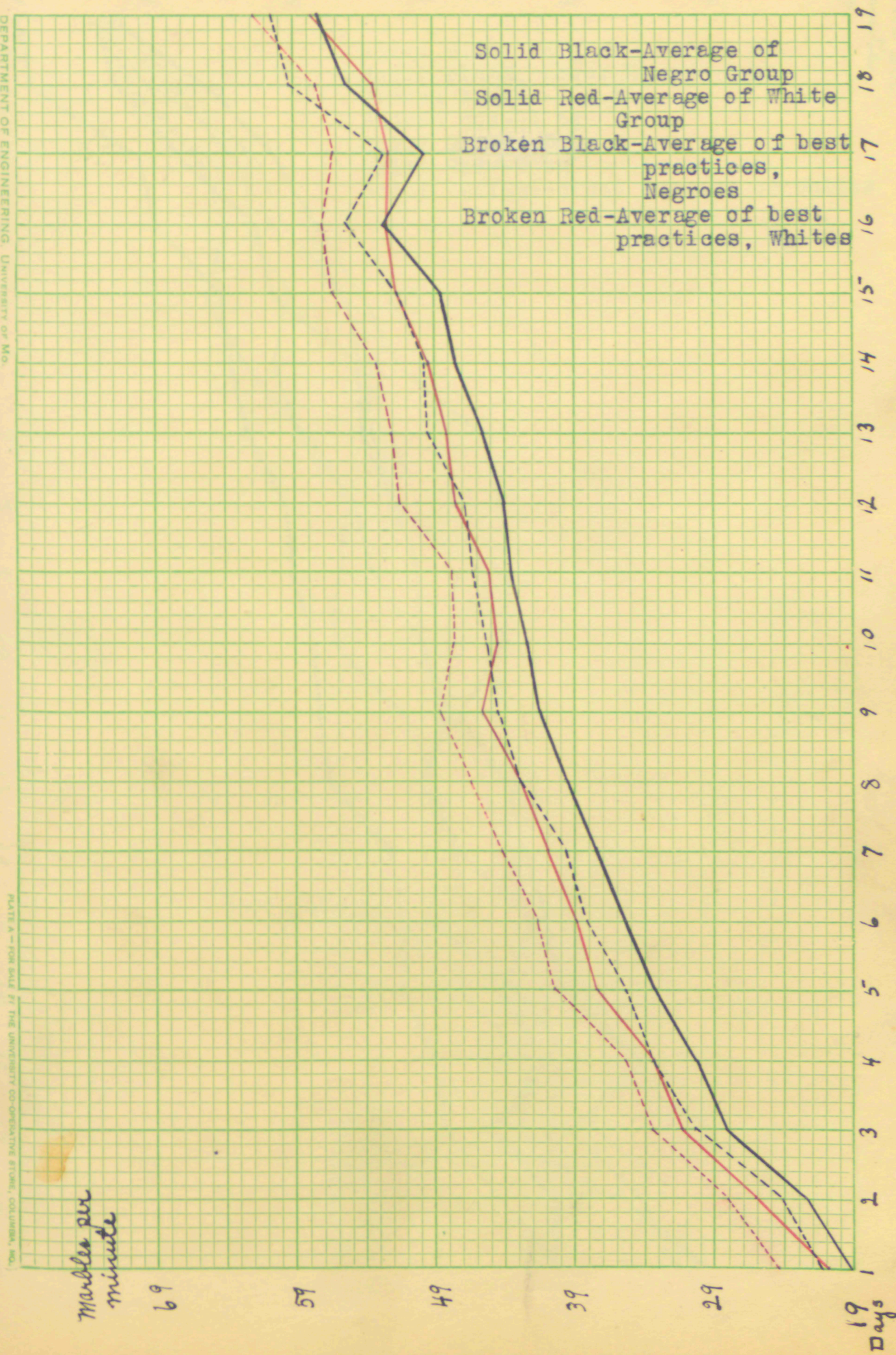




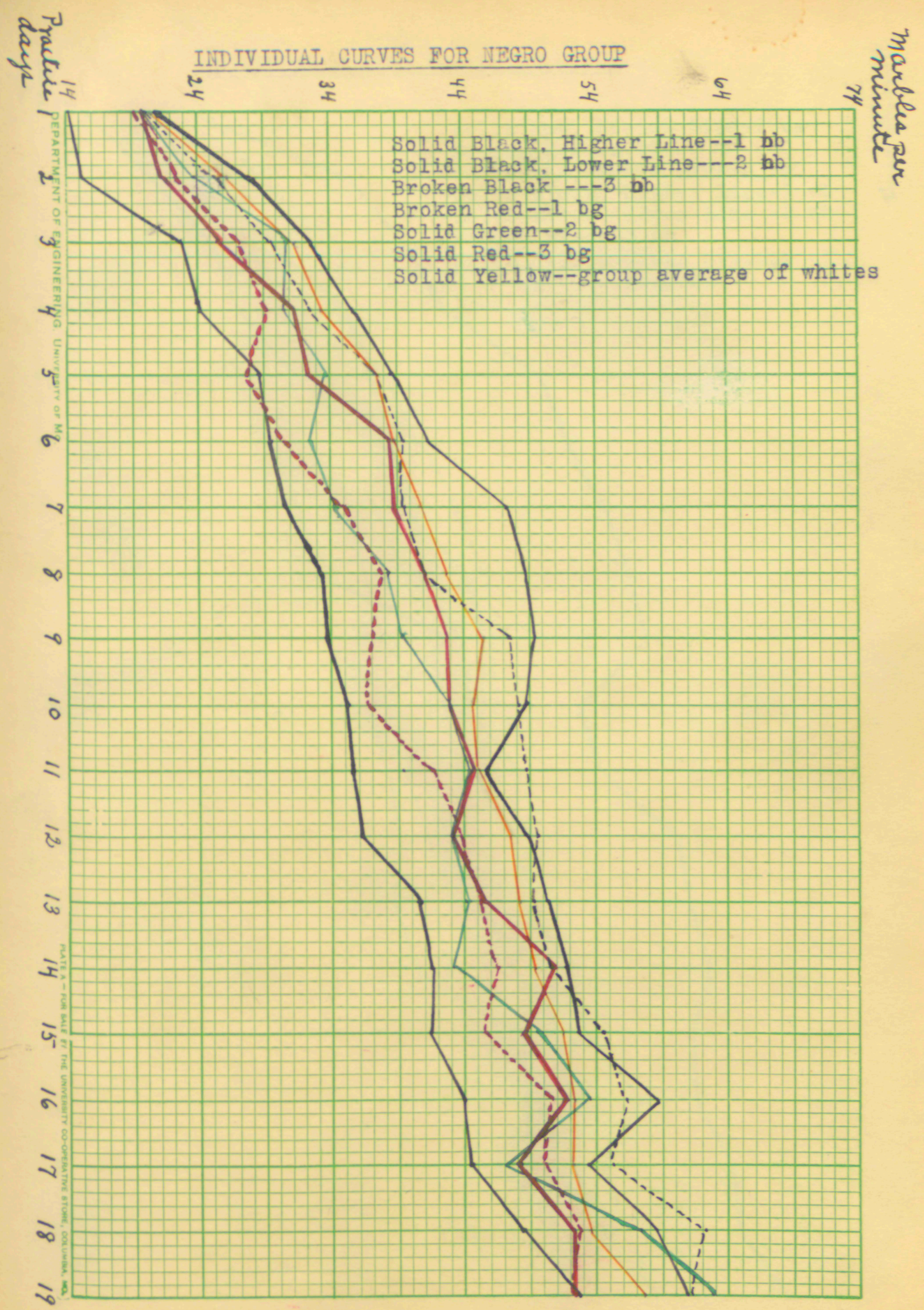




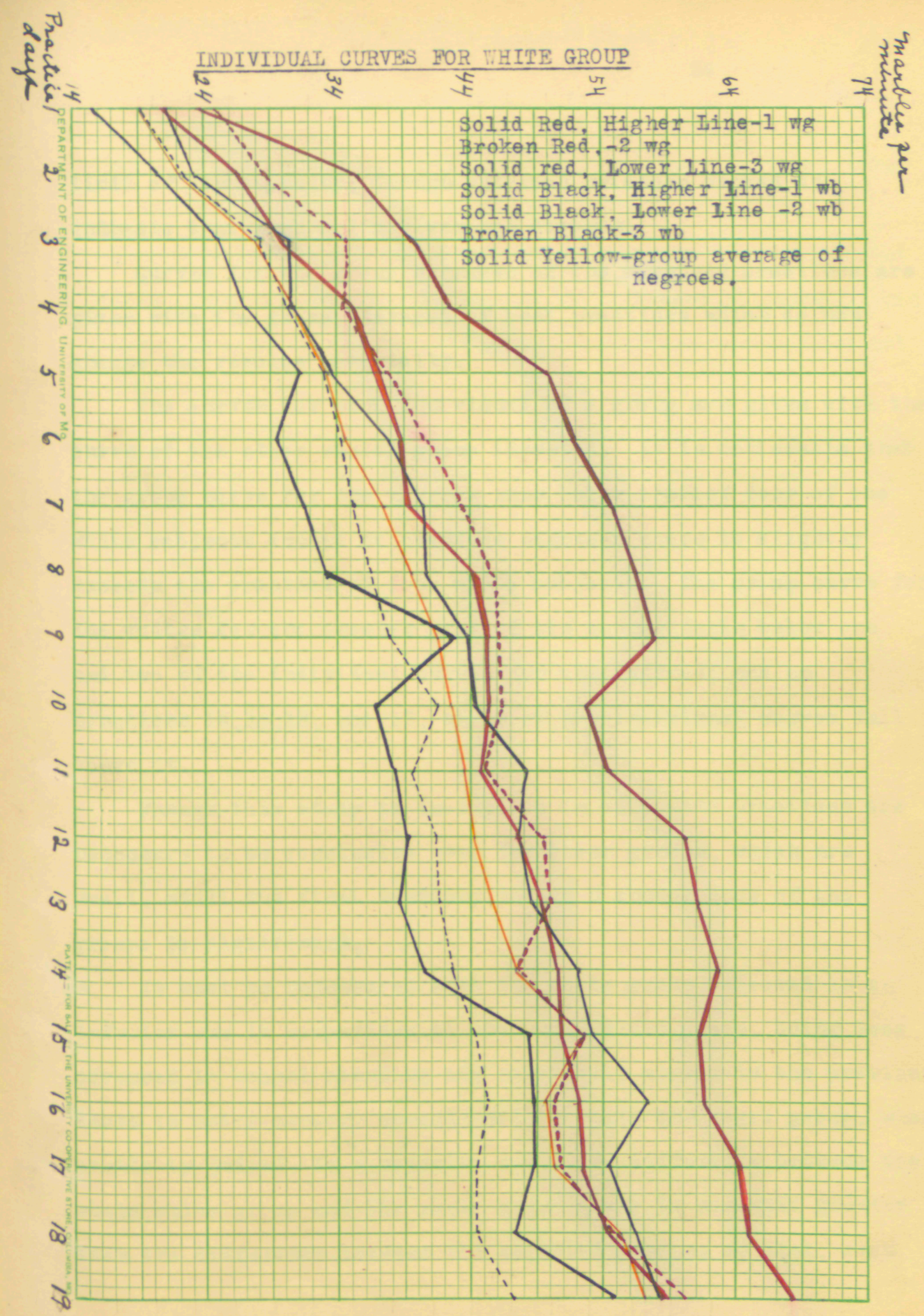


Iimit of its copaoity: though extermal evidence seemed to Indioate tiat siah a limit was not distiant.

Curves for the group arerages of the nineteen practioes are given with the group averages of best practioes whioh do not change the resalts materially.

The ourves for each indiridaal of a group are given with th owro of the other racial groug inserted. It is notiocable that the group carve for the negroes rans below those of four of the wite subjecto exoopt at proctice elghteen where it slight ly erceeds the frectice of four white subjeots. The group ourve for the whites for the greater pert of its course falls belon one and two of the individual oarves for the negroes; and on practioes 14,16,18, and 19, three of the indiridual curves fall abore 1t.

'hough this stady is incomplete in that more practices are necessary to be conolusive even for these groups, which are mall. still the final tendenoy toward a convergence of the groups is significent.

It mast be remombered that the white group selected is an inferior one in comparison to the whole white group, being 1088 adranced in sohool standing and relatively poorer in the previous tests in motor-8ensory oo-ordinat lons while the negro group. when 8imliarly judged. Is a superior one. The differeme between the whole white group and the whole negro group 18 somewhat greater than the difference between the seleoted groups; so that, even 
though the final attainment might be the same, the time taken to achieve it wo:ld be even greater than in this case.

In a learning test of this type, the limit of attainment rould probably be a physiological limit dependent largely upon reaction time which previous experiments have proven does not differ greatly for negroes and for whites.

A comparison of the number of errors made by the selected nerro aroup and the selected white arong snows the whites to be more inaccurate.

Average number of errors per practice.
$1 \mathrm{bg} \cdot .26$
1 Wg $\quad .85$
$2 \mathrm{be} \quad 1.06$
$2 \mathrm{mg} \quad 1.43$
3 bg $\quad 1.40$
3 Ng 1.17
$1 \mathrm{bb} \quad 1.76$
1 wb 1.21
$2 \mathrm{bb}$
.74
$2 \mathrm{wb}$
2.40
$3 \mathrm{bb} \quad 1.17$
3 wb $\quad 1.43$
1.06
1.42

Average

The whites of these selected groips prove to be only 74.6 per cent. as acourate as the nogroes. It will be remembered that $I \mathrm{bg}$ and $2 \mathrm{bb}$, the most accurate of the negro group, were the poorest of the negro group in net efficiency. This is the reverse of what 18 found in studies in individual differences--thet is that the fastest workers are the most accurate workers. Acouracy seems to be the result of thorough habituation, which bringe speed. or of the conoentration of the attention on every step involved. 
In the case of $I b g$ and $2 b b$ the task had not been thoroughly habltuated which was evident from the fact that the hand did not gc anerringly to the right place, bat a change was occasionally nocessary. This caused a loss of speed. Concentrated attention resulted in acouracy. The school records of these two papils shows consolentious work throughout.

Th1s study of the learning capacity of negroes as compared with whites finds the power to form sensory-motor co-ordinations by negroes to be c.bout $72.8 \%$ that of whites, the overlapping between the races to be about $53.2 \%$, the percentage of negroes resching or surpassing tio white median to be $14.4 \%$ and the percentrge of whites reaching or surpassing the negro median to be $87.9 \%$. the saperiority of the whitea to range through all ages from 9-16 with no constant increase or decrease with age, the difference between white bojs and neyro bojs to be less than between white girls and negro girls, the difference between negro boys and negro girls to be 1083 than between white bozs and white girls, the whites to be less superior to the negroes in acouraoy than in speed. the improvement of the negro to be relatively greater than that of the white and the attainment of the negro to approach more slowly the limit of attainment of the white. No otriking racial difference in the course of a day's practice was evident.

In conducting the experiments some slight difforence in the ettltade ct the races ras atteed. In bcth the large gicups 
and the smell groups, the spirit of competition did not enter into the work of the negro group as much as into that of the white group. The negroes were more interested in their own individual reocrds and their improvoment than in their relation to others of the group. The white child had a greater tendenoy to look around to see what the observer and the two of his fellows who were present thought of his performance than did the negrow. When the negro thought ho had made a mistake, he was mach more liable than the white to stop and look around the side of the apparatus to make sare rether than to hold: himself to the task.

The negroes showod a slightly greater tendenoy to work with but one hand than did the whites; also more negroes than whites crossed their hands in getting the marbles called for--trat is the left han would go to the right box for a marble whioh was to be disposed of in a bole at $t$ he right while the right hand went to the left box for a merble thet was to be disposed of in a hole at the left. The negroes were more liable to feel for the marble Instead of looking for it than were the whites. This might point to the prevalenoe of a different ideational type. Rather than drorping the marbles into the hole,t be negroes tended to poke them in with their fingers, and wanted to look down through the holes. When the subjeot was preparing to start work, the negro observers seemed to want to help the subject more than did the white. The negroes were much more liable to say that they knew what to do when they could not repeat the instructions to the observer. Both raoes were able to repeat the instructions to the 
observer, seomingly to anderst and the procedure thoroughly, but hed much greater dffloulty in putting the instructions into effeot. That school chlldren learn the theorg of an operation 80 readly and have so much difficulty in its execution seems to show a need of greater practical application of theoretical knowledge. 


\section{III}

\section{SOCIAI CONSIDERETIONS}

A rouph classiflcetion of the neproes asoording to siin

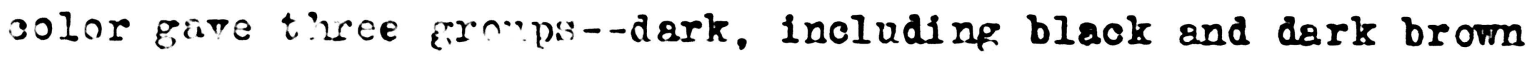
nefroes: medium, including light brown and jellow negroes; 11Rht. Including those of very light skin and evidence of white blood in the ojes and halr.

The objeot in maring the olaselfication was to learn whether there were ang noticeable proun alfferences in home conditions, sobolast io attalnment, and ablisty to baild ap sensory-motor co-ordinations. If such differences were found to exist, they coild not be attributed to admixturo of races. exoept perhaps difforences between the two extreme groups. The fact that there are full blooded negroes ghading from black to light yellow, acoording to the part of Africa from which their ancestors came, makes anj comparison whose basis 18 admizture of raoes 1mpossible mithout lnowing the ancestory of each negro olassifled. The best that cen bo expected from tris study is to g17. som 1des of the validity of a judrment based on the skin color of a negro. Whetier the difference that may exist is due to an admisture of white blood or to a lighter African strain.

74 negroes were olassified as dark, 68 as medium, and 20 as IIght.

All negroes whom the teachers felt capable of judging were olassifled as coming from good. medium, or poor homes accordine to their standinf in the negro community. 82 pupils were grouped 
as coming from good homes, 83 from medium homes, and 45 from poor homes.

The teachers also selected the best five and the forst five scholars in each room. As the high school classes were small, the high school was treated as one unit. This made a renort of 25 best and 25 worst soholars.

As all the pupils in one classification were not reported in tise otier ciassifications because of absences, new entries. and laok of knowledge of home conditions, the total numbers in the following comparisons will not always agree with the numbers reported abore.

The table belon glres the number of dark, mediam, and light negroes coming from good, medium, and poor home conditions and the pereentage of dark, medium, and light negroes found in good. mediam, and poor home conditions.

\begin{tabular}{|c|c|c|c|c|c|c|c|c|}
\hline Bome Conditions & & DARK & MED & IOS & & LIG & GHT & 'TOTAL \\
\hline & Numbe & $\because 8$ & 'Nambe & $\%$ & & Namber? & $\%$ & 'Inamb \\
\hline Good & 20 & $!^{27.0}$ & : 39 & :57.3 & & 12 ' & 60.0 & 71 \\
\hline Yodium & 36 & $: 48.6$ & : 25 & 36.7 & & $3:$ & 15.0 & 64 \\
\hline Poor & 18 & ?24.1 & : 4 & 5.8 & & 5 & 25.0 & : 27 \\
\hline Total Nambe & 74 & : & : 68 & : & & 20 & & : 162 \\
\hline
\end{tabular}

Yodium and light negroes heve shout twioe the probebility of coming Irom good homes t.s do dark negroes. Dark and light negroes have about four times the probability of coming from poor homes at io medium negroes. The medium negroes heve $94.0 \%$ 
of their number ooming from good and medium home conditions as comared with 75.6\% of dark negroes and $76.0 \%$ of light negroes. The distribution of the dark negroes the most nearly normal distribution; the distribution of medium negroes is the most satisfactory from a social standpoint, and the distribution of the light negroes is the most irregular distribution. There are $t$ wo suppositions that mey account for the greater irregularity $f$ the light group. Social predjudice may be such as to faror the advance of the light negro rather out of proportion to $t$ at of the darker, also, an admixture of superior white bl od in distant generations might tend to produce superior home conditions while a recent admixture of degenerate white blood wo:ld produce poor home oonditions.

\&. comprison of àrk, medium, End light negroes according to soholastio attainment civos lise following aistrivution in terms of tho number of black, medium, and light negroes in the group of best and worst pipils and the percentages of the total number of bleck, medium, and light negroes represented among the best and worst pupils.

\begin{tabular}{|c|c|c|c|c|c|c|c|}
\hline Papils & Bl80k & & Medium & & Light & & Tot al \\
\hline & Number & $\%$ & Namber & $\%$ & Iramber & $\%$ & Number \\
\hline Best & 11 & 14.7 & 9 & 13.2 & 3 & 15.0 & 23 \\
\hline Morgt & 12 & 16.2 & 10 & 14.7 & 1 & 5.0 & 23 \\
\hline To tal & 23 & 30.9 & 19 & 27.9 & 4 & 20.0 & \\
\hline
\end{tabular}

Dark, medium, ind light negroes seem to have practically the ac me probabillty of being found among best students, and 
dark and mediam negroes have about three times the probabilit. of b eing found cmong poorest students. $80 \%$ of light negroes. $72 \%$ of medium negroes, and $69 \%$ of dark negroes fall in the rank of medium scholars. This gives the durk negro a slightly

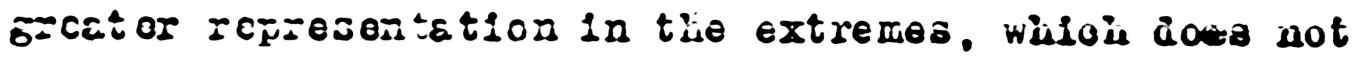
necessarily mean thet the derk negroes are the nost varichle in the sense of goling absolut aly lorer and absolutely higher in tise renge of distribation.

\& comperison of the deviations from their age and sex norms of ti.e dark, the medinm, and the light grouns in their abilits to build up sensory-motor co-ordinations gives the following results for first and seoond triels.

$\begin{array}{lccc}\text { Namber of lases } & \frac{\text { Dark }}{63} & \frac{\text { Medinm }}{55} & \frac{\text { Iight }}{13} \\ \text { \% A.D. Trial I } & 15.1 & 15.9 & 15.9 \\ \text { \% A.D. Trial II } & 12.2 & 13.4 & 18.6\end{array}$

The number of light negroes, 13, is too small to jield a relieble comarison. The difference in variability between the groups on both first and second trials is smell. It is noticeable, however, thet dark and medium negroes are slightly less variable on seoond trial than on first while light negroes are slightly more variable on second trial than on first. The differenes are practically insignificant, however.

The results of an attembt to leam wiether dark, medium, or light negroes build up sensorg-motor so-ordinations most quiokly are given bolow. 


\section{Percentege A. D. above or belor the age norms.}

$\begin{array}{lccc} & \text { Dark } & \text { Ledinm } & \text { Light } \\ \text { Namber } & 63 & 55 & 13 \\ \text { Triel I } & -2.0 & +1.4 & +4.5 \\ \text { Triel II } & +1.6 & -.7 & +5.4\end{array}$

As such small derlations above or belor the average will (1.e.are less than the probable error) easily be lost in the probable error, there seems to be no significance in skin color alone as an index to the ability of negroes to build up such co-ordinations. A strict classification of negroes aucordinf to $t$ he dmixture of races, regardless or regardful of skin color, might reveal correspondingly different abilities but skin color alone wil not yield a reliable criterion.

Taling the best and the worst 20\% of all the negroes tested eccording to their ability to build up sensory-motor co-ordinetions, and dividing these upper and lower classes aocording to color, the following percentages of dark, medium. and light negroes are found to be represented in the best and the wor st groups.

$\begin{array}{lccc} & \text { Dark } & \text { Medinm } & \text { Ilght } \\ \text { Best } & 15.8 & 16.3 & 23.0 \\ \text { Horst } & 25.3 & 21.8 & 23.0\end{array}$

As only 22 of $t$ he best group and 31 of the worst group were classifled according to color, this comparison can have littlo meight. 
It seems to indicate, however, that the light group has a

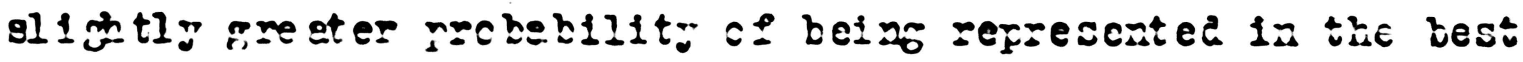
group in ability to build up sensom-motor co-ordinations.

The teachers of $t$ be Jefferson Sohool. where the test for bailding up sensory-motor co-ordinations was given to white children. selected the best five and the morst five scholars in each room end classified their pupils as coming from good. medium, and poor home conditions. It is pertinent to remember that the Jefferson School has in its school population some proportion of the children of shoe ctory workers.

Several methods were taken to determine the effect of good, medium and poor home conditions on the pupils.

Method I.--Rach chlld's record in the sensory-motor test was comared with its age. sex, and race norm, end its deviation above or belor the norm was recorded. All deviations above or belor were then grouped acoording to home conditions, the races being kept separate. The peroent afe deviation was then computed. The following tables give the results.

Per cent. deviation above or below the age and the sex norm of sohool chlldren from different home conditions.

Trial I

Negroes

Home Cond it i ons $10 . \%$ Deviation

Good

Mediam

Poor
$71+2.5$

$59+1.1$

$33-6.6$
Trial II

Whites Negroes

No. \% No. \%

$41-.4$

$71+1.1$

$74+3.0$

$59+.7$

$\begin{array}{llll}58 & -4.4 & 33 & -3.1\end{array}$
Thites No. \%

$41-1.4$

$74+.8$

$58-2.0$ 
As the deviations are small and easily fall within the probable error, home conditions should be a very amall factor in determining the schlerement in this test.

Hethod II.--OP all the negroes and thites tested, the best $20 \%$ and the rorst $20 \%$ were seleoted from the different ages for esoh sex and for each race. The groups thus selected were then divided according to home conditions. Twenty-one negro g1rls. and fourteen negro boys, and tmenty-one white girls and fifteen white hoys were the numbers ennmeimeting $20 \%$ of the whole numbers. For the negroes tro of the best group and two of the worst group were not recorded as to home conditions, and for the whites 8 ix of the best groun and five of the worst group were not reoorded. These are not represented in the folloring tables which give the number falling into each class of home condition and the ner cent. of ell children of each race from good, mediam, and poor home conditions represented in the best and worst proups.

\section{Negroes}

Best

Home Conditions Number \&
$10 \quad 14.0$

1423.1

824.2
Whites

Worst

Best

$5 \quad 12.1$

$18 \quad 24.4$

$7 \quad 12.0$ $11 \quad 15.6$

$12 \quad 20.3$

$10 \quad 30.3$
Namber \& Number $\%$ Number $\%$

Worst
$5 \quad 12.1$

$13 \quad 17.5$

1322.4

For the neproes this method shows no great influence of home conditions. Though those coming from poor homes are about 
twioe as liable 88 those from good homes to fall into the worst groud, they are also twice as liable to fall into the best groun. The noor group has a greater representation in the extremes thein has the good groun. but such a state could hardly be seid to be the result of noor home conditions. Both conditions are more $110 \mathrm{ble}$ to be attendent unon a third.

In considering the white groap. It is noticeable that those coming from good home ccnditions are as liable to be represented in the best as in the worst class, while those coming from poor homes are about twioe as liable to fall into the poor group as into the good group and their representation in the poor group Is about twice 0.8 large 8.8 the representation of those coming from good home conditions. In this case it seems more than Iikely that poor home conditions is the result of poor hereditary stock? which also cond itions poor ability. The poor standing in the test then 18 releted to the same canse thet has trought about poor home conditions and is not the result of poor home conditions.

The differenco in this method of comarison between the distribution of the negroes and the writes coming from poor home conditions is probebly due to the longer existence of the whites in their present status in wociets. In very roung communities, rich and poor. families of good hereditary stock and of poor hereditary stock are found living in practically the same conditions. In an older community, the richer, the more industr10us, the more intelligent. and the better naturelly endowed can be distinguished from the poorer. the less indastrious. the lgnorant, and the poorly endowed in natural ability by the 
condit lons in which the $y$ ive?. The whites tested come from ancestors who have been living in such a community and have been subjected to such a sifting process. The negroes, Iately emerged from slavery where porerty and ienorance were prevalent and where industry was not rewarded, have not been sabjected to the same sifting process which leaves those most poorly end owed by heredity at the bottom. Another factor which would enter into the explanation of this difference is that the incentires which make the white do his best and so divide natural ability cannot be operative upon the negro in the present stete of social prefjudice. The renge of achievement for the negro is so nerrow and $t$ he height to which he can rise is 80 limited thet incentives for best effort are lacking. "ith such laok of effort. It is about as probable that negroes of best nat ural endowment will te found in poor home conditions as those of worst natural endowment. At the present time, then, good or poor home conditionsis not as good a criterion for judging the Innate possibilities of a negro as it is of a wite.

Hethod III.--Nerro boys and negro girls in best home conditions were matahed $b y$ age and sex with white bojs and with mite girls of poor home conditions. Where more than one mat oh was possible, the rule for random selection was observed. In this comparison the negro homes of best rank and the white howe of rorst rank should certainly not differ greatly in the exoellace of their environment and the variation. 
If present, mould probably be in faror of the negro home. The sixteen white bojs in worst home condicns averaged 16.25 marbles per minute on the first trial and 18.25 on the second. The sixteen negro boys in the best home conditions averaged 13.68 marbles per minute on the flrst trial and 15.81 on the second. The records for nineteen white girls in vorst home oonditions averaged 15.78 on the first trial and 18.94 on seoond trial, end the nineteen negro girls from best homes averaged 12.73 and 14.63 o: flrst and second trial a respectively. If credence can be given to comarison of so fer cases, it seems to point to $t$ he fact thet environmental conditions need not be consldered in judging quickness of learning which depends ?upon hereditary endowment and is not besed on earlier acquired kno.rlo dge .

A comperlacn of the home conditions of the best five and the poorest five pupils, according to the teachers' reports, was made. The number of the best and the poorest pupils and the per cent. of those ranked in the different home conditions represented among best and poorest papils is recorded below.

Ilegroes

Best Pupils Worst Pupils

Home

Good

Medium

Poor

Total No. Ho. \%

1926.7

1423.7

$6 \quad 18.1$

29 so.

811.2

$15 \quad 25.4$

$13 \quad 39.3$

36 罚ites

Best Pupils Forst Pupils No. \% No.

$13 \quad 31.7$

12.4

$9 \quad 12.1$

$6 \quad 8.1$

35.1

$12 \quad 21.0$

25 
(BY GRADE)

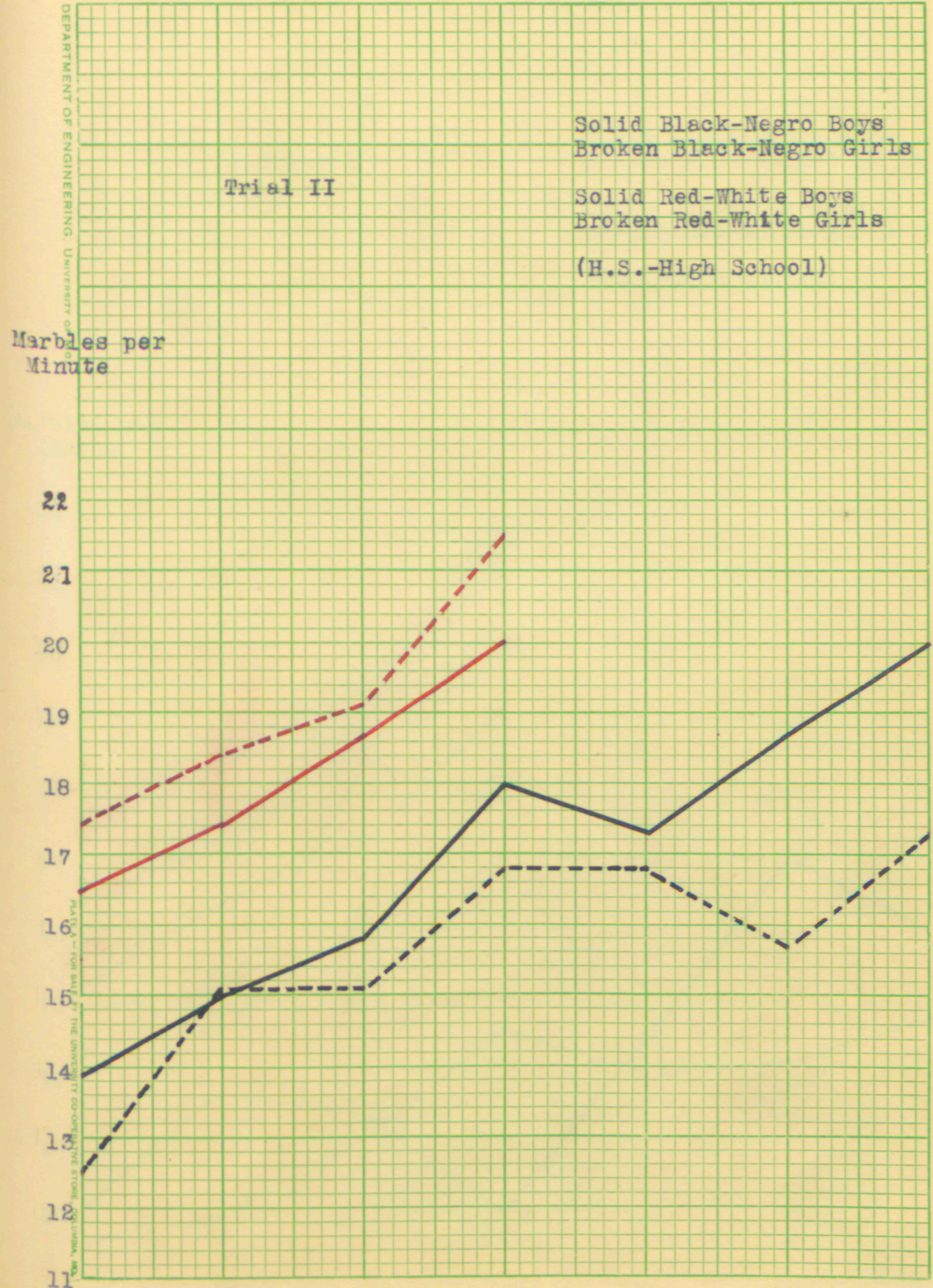

$1 \mathrm{H} . \mathrm{S}$.

$2 \mathrm{H} . \mathrm{S}$.

3 H.S. 
EFFICI BNCY CURVES

(BY GRADE)

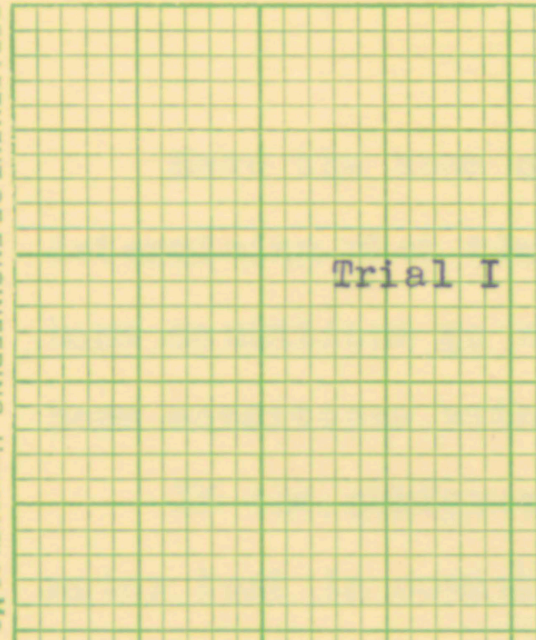

Solid Black-Negro Boys

Broken Black-Negro Girls

Solid Red-White Boys

Broken Red-White girls

(II.S.-High SchooI)

\section{Ma:bles per \\ linute}

32

21

20

19

18

17

16

15

14

Gedes

11

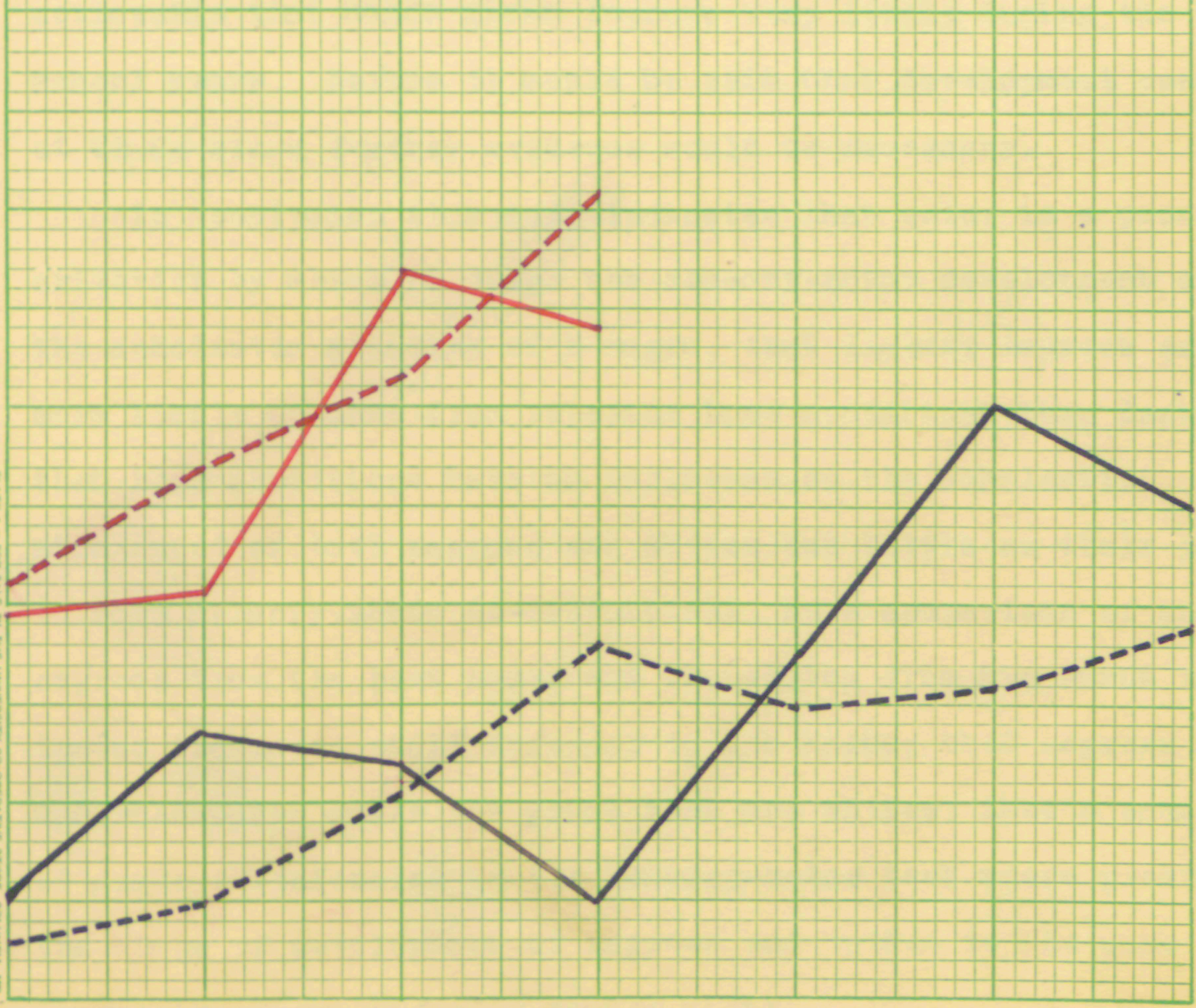

1 H.S.

2 H.S.

3 H.S. 
Here the home conditions nlas a more vital part in determining what $t$ he child may achleve. For both races good home oonditions go with good scholastic at tainment and poor home conditions with poor scholastic ettainment.

If the achierement of negroes and whites in the sensorymotor test is compared grade by grade, the efficienoy curres of the negrces do not touoh those of $t$ he whites in any grade. This is true in spite of the fact thet the negrces are about a jear older in each grade with the exception of the fifth grace where their es are practically the same. It is noticeable thet negro girls improve very little during the high school years. Before it could be said thet development ceases at th is stape, fur ther evidence would be necessary.

In conolusion this stady indicates that color is a poor oriterion by which to fadge the sensory-motor development or the scholast te standing of a negro: that lighter negroes are more liable to come from superior home conditions than darker; that home conditions have an influence on the scholastic attainment of both negroes and whites but little on their power to form sensory-motor co-ordinations, as a comparison of the negroes from the best homes and the whites from $t$ be worst homes leaves the negro still inferior to tre white: that neproes are somewhat older grade per grade than are whites: that a comparison of grede efficienoies in the senscry-motor test where presumably the stege of development of negroes and whites is the same leares the negro inferior to $t$ he white. 
PHYS ICAT IMEASUREITAITS

The object of this study was to determine whether there wore any fandemental differ enoes betreen negroes and phites in phrsical prowth and development.

The Depertment of Educational Psychology supervised the measuring of 693 white girls and 621 white boys of the public sohools of Columbia, Ulssouri, anc 233 negro boys and 280 negro girls of the public schools of Lexico, Hiss juri, and columbia, Missour1. The ages of the subjects ranged from five to twenty years. The number of cases at 5,16,17,18, and 19 are too small to be of great value, but from 6 to 15 the number of children at euch age is large enough to give fairly valid resalts..

Height.--The me asurement $s$ of height were made by the use of a stadiometer and a micrometer, the heel height being subtracted from the to tal height. The carves on the following pege show the inorese in beight for the age 6 to 15 .

The difference in 8150 between the races is slight, but there is some rariation in the crossing of the sexes. The negro boys and girls are practically equal in height unt 11 nine years of age when the growth ourves separate and the girls are taller unt1l after the fourteenth jear. The inite girls cross the white boys some what later, belng taller from about twelre to sixteen years of age. The differene between the negro bogs and girls is somerhat grecter $t$ han between white boys and girls. 


\section{Cent imeters}

Solla Black-Negro Boys

Broken Black-Negro Girls

180

Solia Red-White Boys

Broken Red-White Girls

170

160

西 然

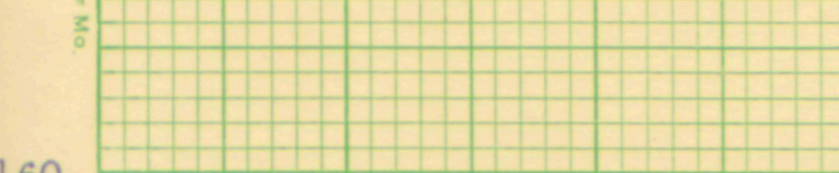

150 140

120

115

210 105

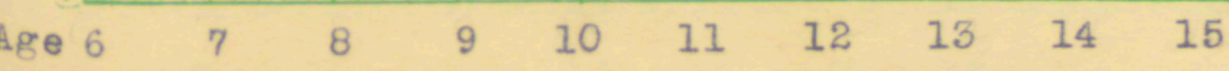




\section{Centimeters}

Solid Black-Negro Boys

Broken Bleok-Negro Girls

Solid Red-White Boys

Broken Red-White Girls

70

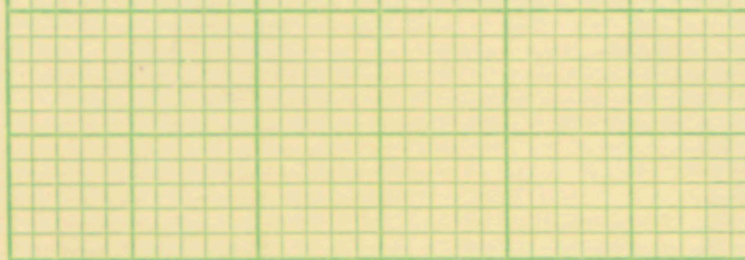

5

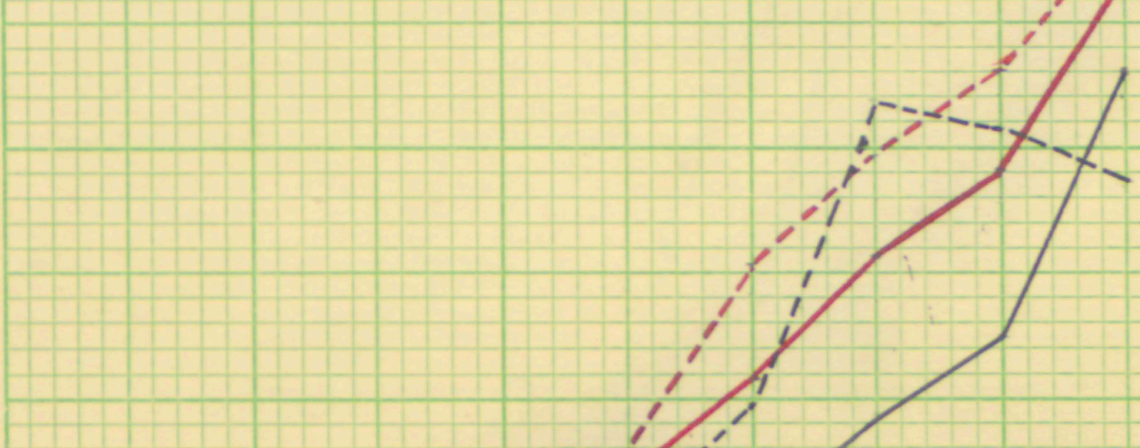

65

60

55 


\section{Pounds}

125

120 Solia Black-Negro Boys

115 Broken Black-Negro Girls

Solid Red-White Boys

110

Broken Red-White Girls

105

100

95

90

85

80

75
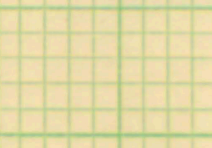

100

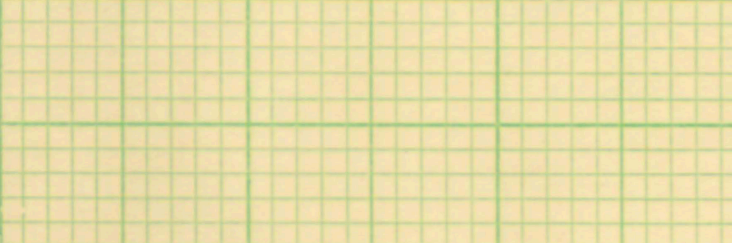


Cubic Centimeters

3025 Solia Black-Negro Boys 3900 Broken Black-Negro Girls

Solia Rea-White Boys $277 \frac{2}{5}$ Broken Reá-Winite Girls

2650

2525

2400

2275

2150

2025

1900

1775

1650

1525

1400

1275

1150

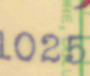

900 
In aitting height, the curves for negroes are approximately the same as for standing height, the growth for girls crossing that of bogs just before the ninth jear and keeping the ascendenor until about the fifteenth year. For frowth in sitting height, the ourve for negro girls stops its rise at thriteen, a year earlier then in standing helght. The growth curve for white girlo rises above that for white bors between the eleventh and the twellh years and keens above until between the fifteenth and s1xteenth years. The divergence between the ourves for thite boys and white girls from 11 to 15 years of ege is slightly greater than in standing height which mey signify 2 more rapid growth of the trank than of the legs for girls during this period. Teight.-- Teight was determined by the use of anthropometrio scales.

The growth curves for inoreased weight show the pegroes hearler than whitea, From between 9 and 10 to between 14 and 15 . the negro girls are heavier than the negro boys; and from between 10 and 11 to about 15. winite girls are heavier than white boys. Lung Cayelty.--Iiane capacit was determined by the use of a wet splrometer.

The curres show that whites have a considerably larger lung capacity than have the negroes, whites of both seres surpassing negroes of both sexes at all ages except betreen 14 and 15 where white girlo fall below negro boys in their growth curve. Judging from the limited number of cases at 16,17 . and 18 gears, white girls wovld not again exceed negro boys in lang capacity. Thite 


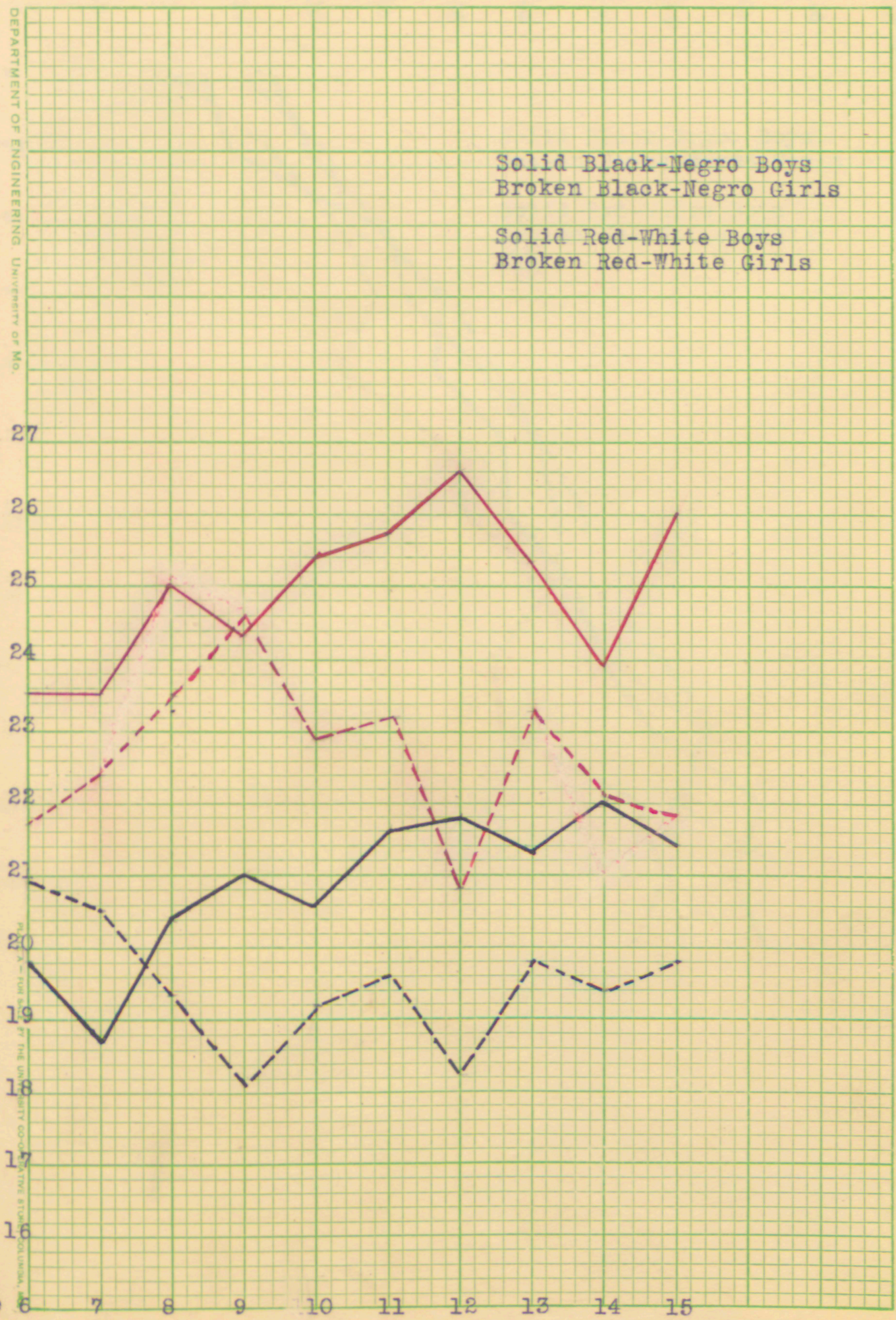


ผे

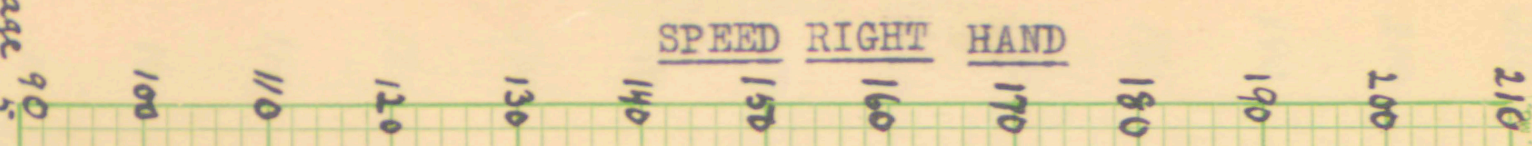

$\sigma$

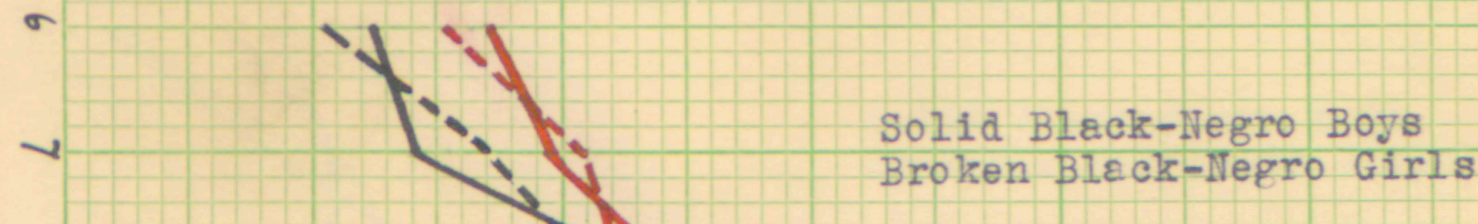

$\infty$

Solid Red-White Boys

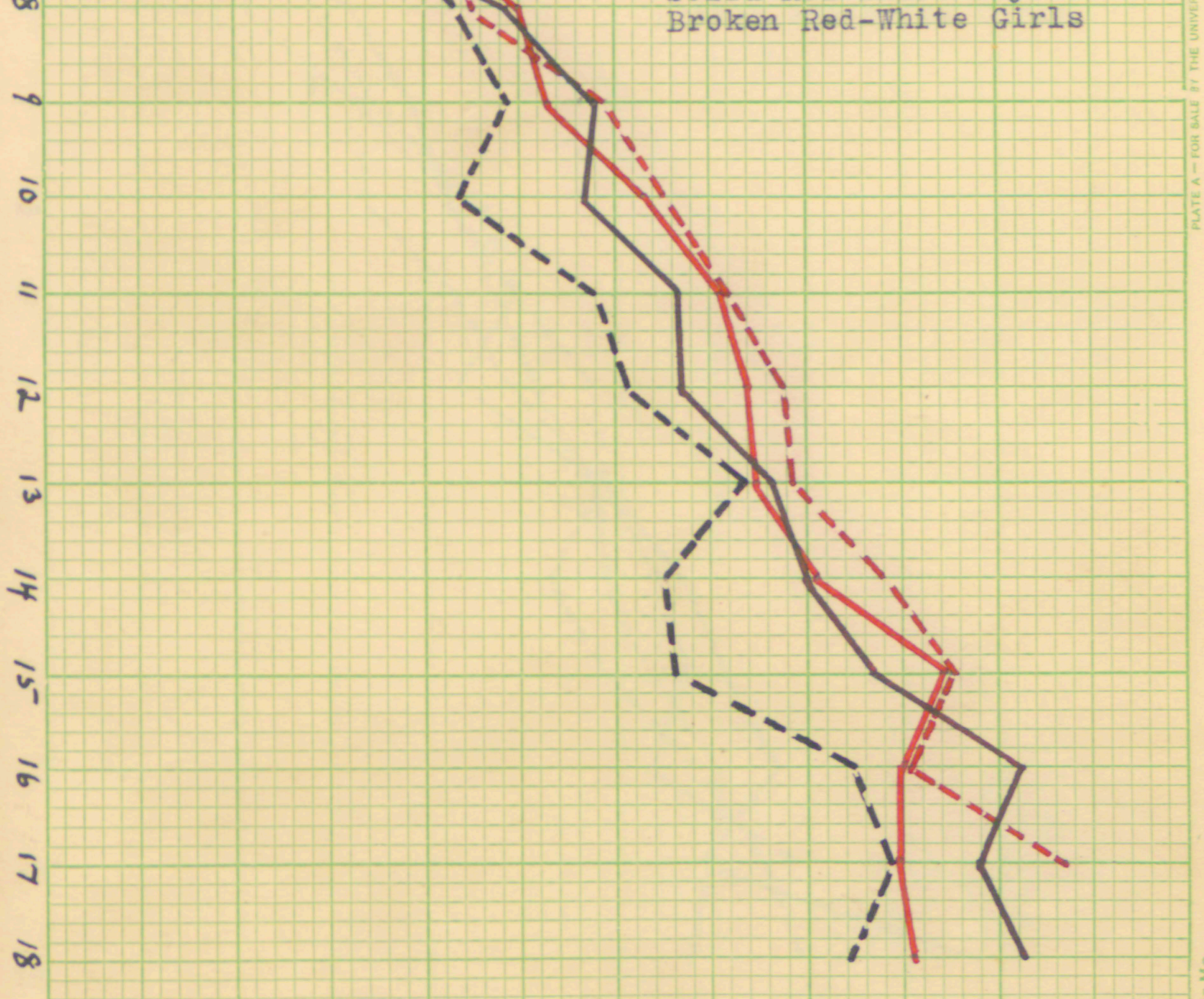




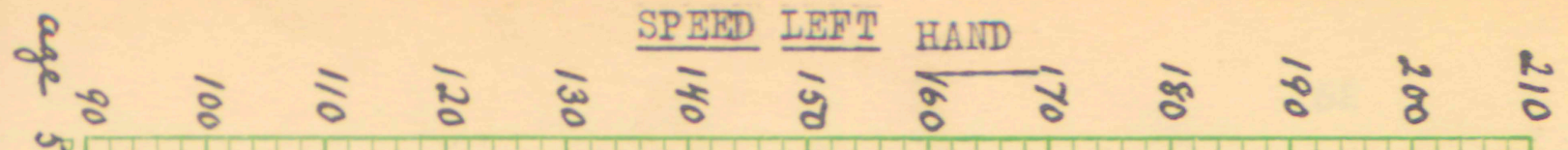
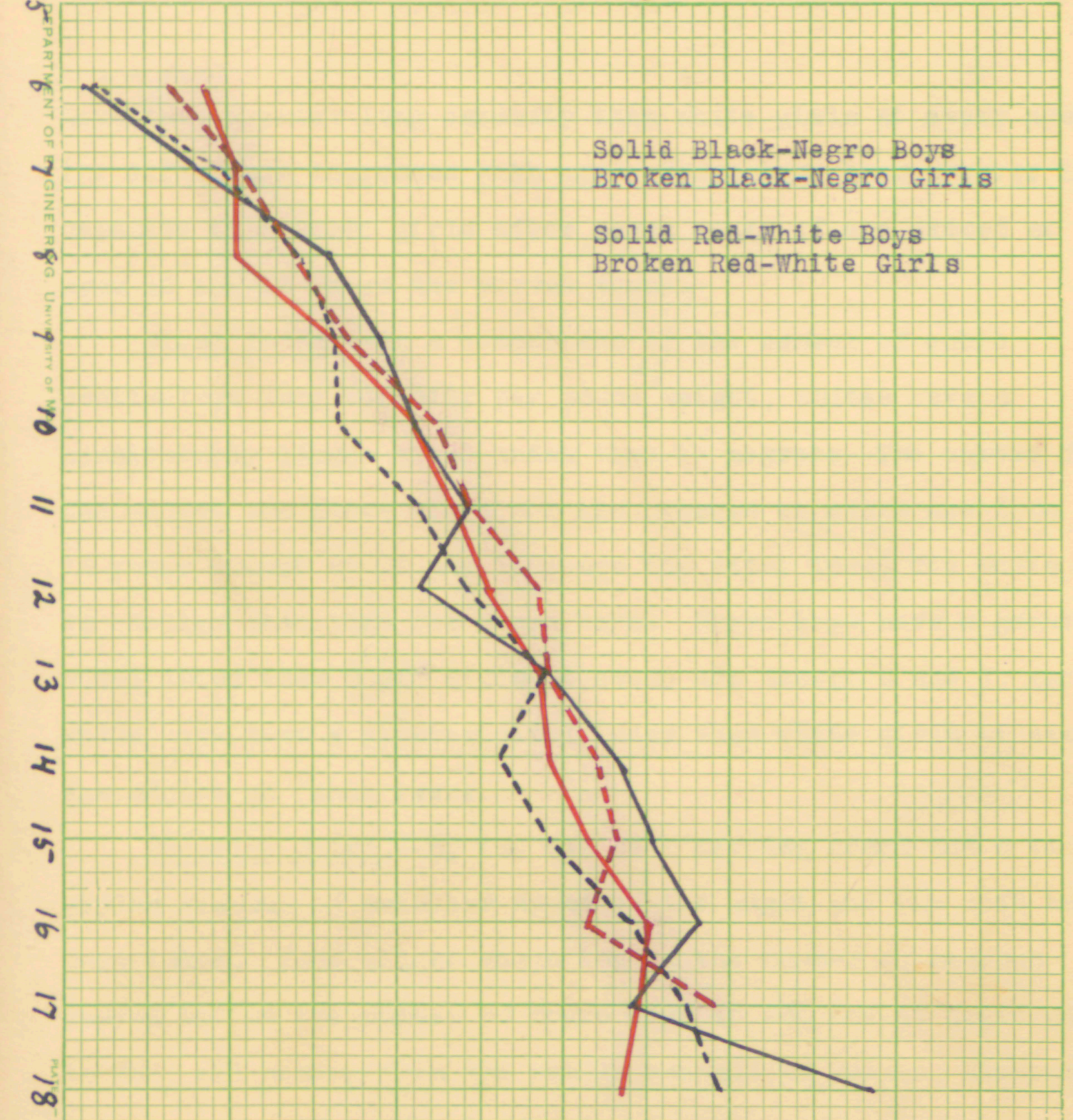
boys have greater lung capaoity than white girls at every age, and the difference increases with age. Hegro bojs have greater lang capacity than negro girls after seren years of age except at ages 10 and 12 where the curves touch.

Vit al Index.--In a comparison of the number of cubic centimeters lung capacity per pound weight, whites rave a considerably larger vital index than do negroes--The curves for the whites are above those for the negroes at every age from 6 to 16 jears except at 12 and 14 where the vital index for wite girls is amaller than that for negro boys. Negro boys have a greater vital index than negro firls at every afe except 6 and 7 , and White boys have a greater $\forall$ tal index than white girlo at every age, except at nine years.

lfuscular Speed.--By the nse of $\varepsilon$ tapping board and a tapping stylus, records of musoulir speed of the right and the left hands were $t$ aken. Some slight variation in the number of negroes tested brings the number of negro bcys to 234 and of negro girls to 256, all coming from the public schools of llexico, Hisscuri and the negro high school of Columbia, Missourt.

For speed of the right hend, whit es are slightly better than negro be yo and congiderably better than negro girls, white girls olightly better than mite boys ind negro boys better than negro girls. After nine years of age, little crosef ng occurs.

The curves for left hand opeed shor the races to be practically equal, proving the negroes to be the more ambidexterous. The auperiority of negro bojs over negro girls is kept 
की BRIP RIGIT

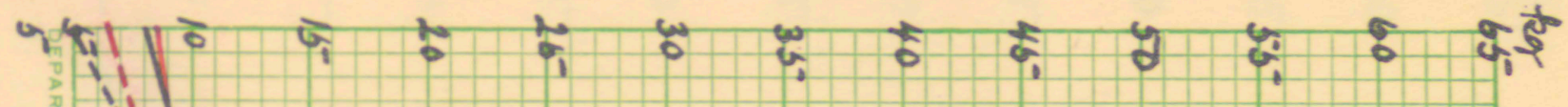

and

il

隹



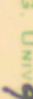

(1)

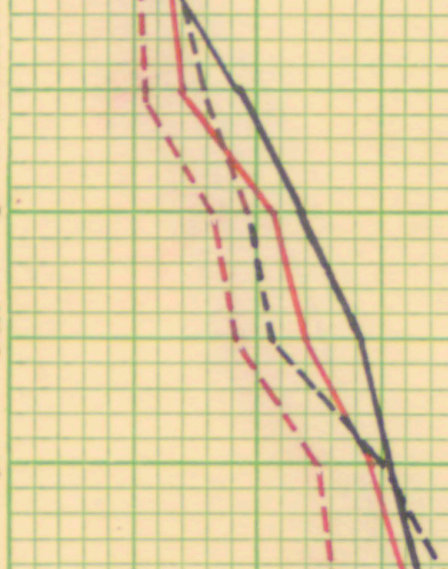

i

is

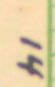

s.

2

ฟ

के

Solid Black-Negro Boys

Broken Black-Negro Girls

Solid Red-White Boys

Broken Bod-White Girls

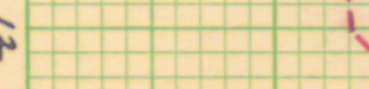

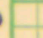

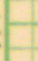

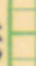
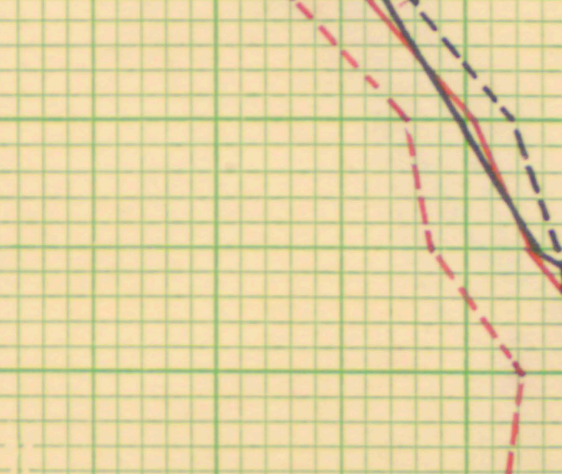

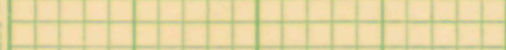
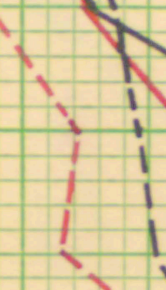

$\sqrt{1}$
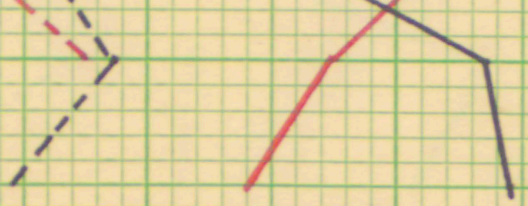


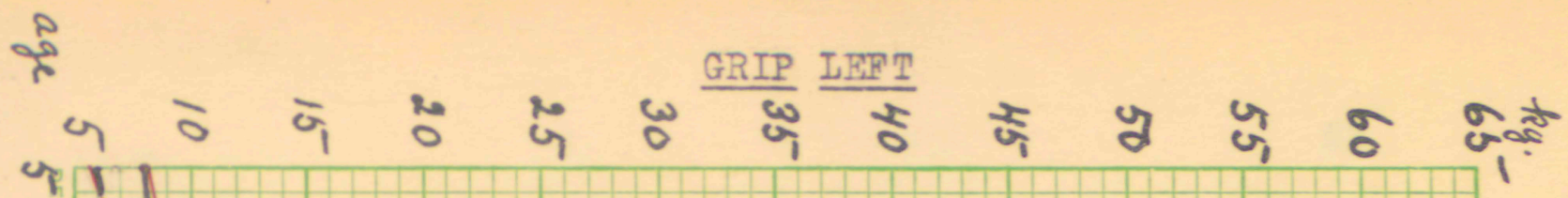

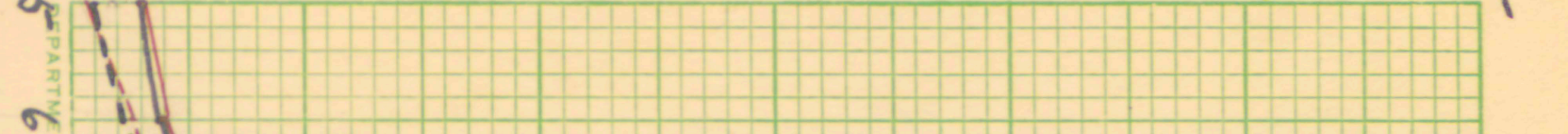

Solid Black-Negro Boys Broken Black-Negro Girls

Solid Red-White Boys Broken Red-Thite Girls 
Irom 8 to 16 jears, and from 11 to 16 jears white girls are saperior to white boys.

Grip.--ihe strength of grip was determined by the use of the improvea form of smedley's dynamometer. Whree trials were given alternate ly to each hand.

In grip of both right and left hands, white girlo are noticeably reaker than white boys and negro boys and girls. Thite boys and negro girls are about equal until fourteen years of age wherc the curve for white bors rises above that for negro girls. At ages 7 and 11 the cerve for strength of right hand for negro girls touches that for negro boys, and from 12 to 14 rears negro girla are stronger then negro boys in right grip. Negro boys are etronger than white bojs except from 12 to 14 and just after 15 jears of age. There is little evidence of ambidexterity in grip.

In summarizing, this evidence indicates that the races are about the same in standing and in sitting height, that the negroes are considerebly heavier. that the whites have a greater ling capacity and vital index, that the whites have a somewhat quiker muscular reaction with the right hand than the negroes and are practioalig the same as the negroes with the left hand. that $t$ he negroes are somewhat atronger in both right and left grips, and thet the negroes are more ambidezterous in speed but not not iceably 80 in grip.

Es the negroes are as tall and are heavier than the whites. their actuelly smaller lung capacity and vital index may play 
un important part in their resistance to disease through a less thorough oxication of the blood.

The derelopment of the negro physically seems to be more rapid than that of the rhite as is indicated by the earlier age at which the increased rate of growth, due to the pubertal change, causes the growth curves for height, weight, and speed of negro girls to gain the ascendenoy over those of negro bogs and the accompenying earlier 1083 of the girls to the voys at the period of their increased growth than in the case of white boys and whit girls. This earlier physical development would accompeny the earlier mental dovelopment that is saggested in the Binet study of Alioe C. Strong and in the work of C. E. Ragsdale where it is found that the difference between the races decreases with age. 


\section{SORIARY}

The study which has fust been reported finds some striking raotal differences between negroes and whites.

In building ap sensorg-motor co-ordinations, negroes were found to be $72.8 \%$ as efficient as whites and the overlapping betreen the reces to be but 53.2\%. Of the negroes $14.4 \%$ reached the white median while $87.9,5$ of the whites reached the negro median. At every age from 9-16 the whites were superior to the negroes, white girls being more superior to negro girls than white bogs to negro bogs. Negro bo:s were slightly better than negro girls, and vhite girls were better than white bogs. The difference between whites and negroes was greater in speed than in accuracy. and the improvement of the negro was greater relatively than that of the white, showing a possible tendency of the negro to approach more slowly the limit of attainment of the white.

skin color, which has so long been the basis for judging the intelligence of negro, does not seem to be a reliable oriterion for judging his nat ive abilit: to bailo ap sensorgmotor oo-ordinations or his ability to attain scholastic success. The home conditions of negroes do not seem to have a vital effect on their native abllity but do on their abllity to achieve. As the group of negroes coming from the best home conditions are inferior to the eroup of whites coming from the worst home conalticns, the environtent of the negro chila cannot to reyponsible for his inferior ablilty to baild ap sensory-motor co-ordinations. 
Negroes and whites are practically enual in height; negroes are heavier and slightly stronger of grip; whites are slightly faster in reaction and of larger lung capacity and vital index; and negroes are more ambidexderous in speed. The physical development of the negro seems to be more rapid then that of the whit $\theta$. 


\section{APPEIDIX}

$\underline{\AA}$

Original data for sensory-motor tests given in the Douglass and Jefferson Schools.

\section{IEGRO GIRIS}

Trial I Fourth Grade Trial II

\begin{tabular}{|c|c|c|c|c|c|c|c|}
\hline $\begin{array}{l}\text { Tattie } \\
\text { Teoile }\end{array}$ & $\begin{array}{l}A g e \\
\text { e } 9-5 \\
9-1 \\
9-7 \\
10-3 \\
9-11 \\
10-11 \\
11-2 \\
10-6 \\
11-8 \\
11-9 \\
11-9 \\
12-0 \\
11-8 \\
11-10 \\
11-7 \\
13-0 \\
12-7 \\
12-9 \\
13-11 \\
13-11 \\
15-3\end{array}$ & $\begin{array}{l}\text { Time } \\
6-25 \\
7-42 \\
6-24 \\
9-38 \\
8-10 \\
9-04 \\
5-15 \\
10-08 \\
8-35 \\
7-02 \\
7-12 \\
8-03 \\
9-04 \\
6-15 \\
5-17 \\
7-57 \\
7-00 \\
7-20 \\
7-24 \\
7-27\end{array}$ & $\begin{array}{l}\text { Error } \\
5 \\
2 \\
3 \\
8 \\
8 \\
12 \\
29 \\
\\
5 \\
4 \\
19 \\
10 \\
7 \\
4 \\
9 \\
7 \\
4 \\
11 \\
24 \\
24 \\
5\end{array}$ & $\begin{array}{l}\text { M.P.I } \\
14 \\
12 \\
15 \\
9 \\
11 \\
9 \\
13 \\
9 \\
11 \\
10 \\
12 \\
11 \\
10 \\
14 \\
17 \\
12 \\
12 \\
10 \\
10 \\
12\end{array}$ & $\begin{array}{r}- \text { Time } \\
5-52 \\
7-42 \\
7-06 \\
7-54 \\
8-11 \\
8-40 \\
5-05 \\
7-30 \\
7-58 \\
6-20 \\
7-10 \\
7-40 \\
6-57 \\
5-37 \\
4-40 \\
8-35 \\
6-35 \\
6-45 \\
7-16 \\
7-26\end{array}$ & $\begin{array}{l}\text { Error } \\
2 \\
4 \\
1 \\
8 \\
2 \\
5 \\
13 \\
\\
5 \\
1 \\
18 \\
0 \\
13 \\
5 \\
8 \\
10 \\
5 \\
3 \\
20 \\
27 \\
6\end{array}$ & $\begin{array}{l}1 . P . M . \\
16 \\
12 \\
13 \\
11 \\
11 \\
10 \\
16\end{array}$ \\
\hline
\end{tabular}

Pifth Grade

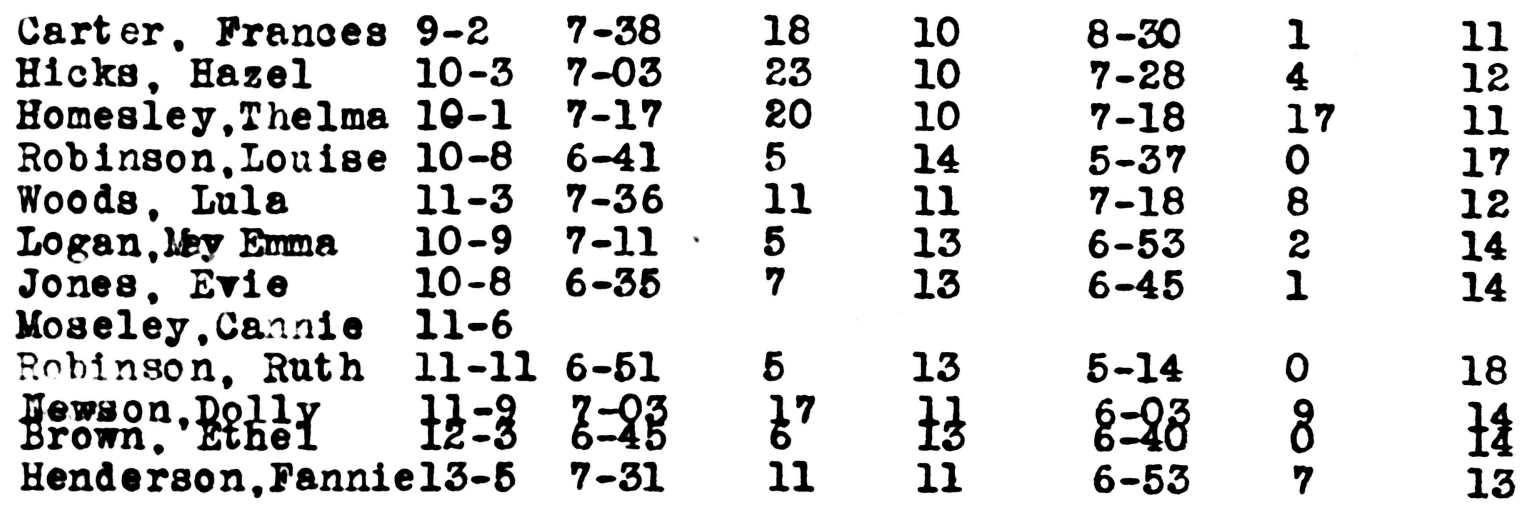


NEGRO GIRIS

Trial I

$\begin{array}{lll}\text { Name } & \text { Age } & \text { Time } \\ \text { King, Beulah } & 13-0 & 6-30 \\ \text { Woods, Glara } & 14-0 & 6-25 \\ \text { Smith, Katherine } & 14-9 & 6-30 \\ \text { Robnett, Viola } & 15-6 & 7-14 \\ \text { Harvey, Ardellal4-10 } & 6-37 \\ \text { Turner, Hals8a } & 17-0 & 9-05\end{array}$
Fifth Grade

Error M.P.1S.--Time

$\begin{array}{lll}13 & 13 & 6-05 \\ 8 & 14 & 5-57 \\ 2 & 14 & 5-40 \\ 16 & 11 & 5-32 \\ 4 & 14 & 5-34 \\ 12 & 9 & 8-05\end{array}$

Trial II

Error II.P.M.

$\begin{array}{ll}7 & 15 \\ 2 & 16 \\ 2 & 17 \\ 3 & 17 \\ 5 & 16 \\ 2 & 12\end{array}$

Sixth Grade

\begin{tabular}{|c|c|c|c|c|c|c|}
\hline 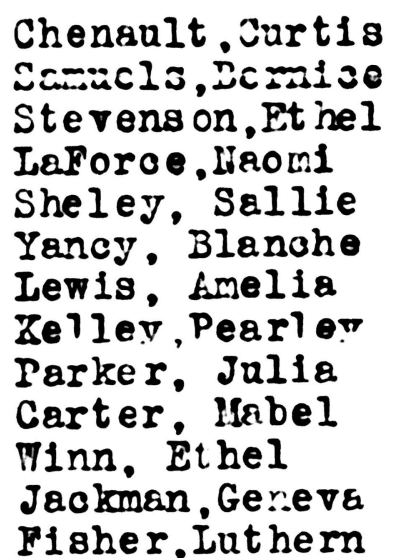 & $\begin{array}{l}10-9 \\
10-2 \\
11-2 \\
12-2 \\
12-0 \\
13-2 \\
13-0 \\
13-7 \\
14-3 \\
15-1 \\
15-6 \\
15-1 \\
16-6\end{array}$ & $\begin{array}{l}6-18 \\
7-48 \\
5-57 \\
9-00 \\
6-06 \\
7-13 \\
6-48 \\
8-49 \\
6-16 \\
5-33 \\
6-26 \\
6-51 \\
5-45\end{array}$ & $\begin{array}{l}3 \\
20 \\
0 \\
20 \\
17 \\
5 \\
0 \\
11 \\
4 \\
16 \\
2 \\
0 \\
18\end{array}$ & $\begin{array}{l}15 \\
10 \\
16 \\
8 \\
13 \\
13 \\
14 \\
10 \\
15 \\
14 \\
15 \\
14 \\
14\end{array}$ & $\begin{array}{l}5-55 \\
8-25 \\
5-41 \\
8-35 \\
6-29 \\
7-23 \\
6-36 \\
6-22 \\
5-35 \\
4-30 \\
5-58 \\
5-28 \\
5-20\end{array}$ & $\begin{array}{l}0 \\
4 \\
5 \\
19 \\
2 \\
1 \\
1 \\
3 \\
2 \\
1 \\
2 \\
1 \\
1\end{array}$ \\
\hline
\end{tabular}

Seventh Grede

\begin{tabular}{|c|c|c|c|c|c|c|}
\hline 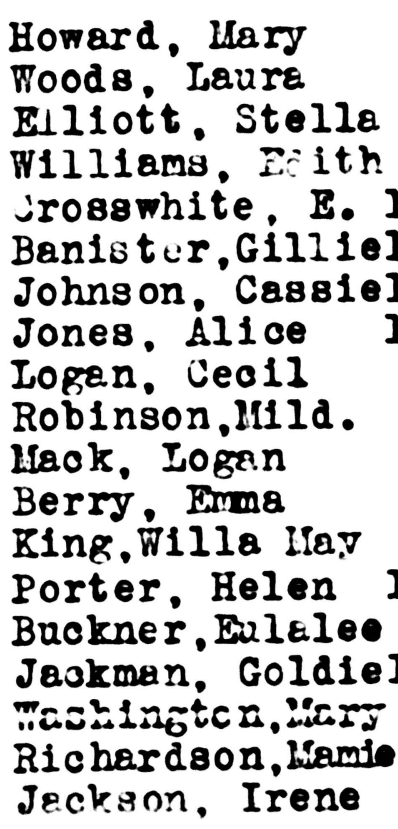 & $\begin{array}{r}11-1 \\
11-6 \\
12-3 \\
11-8 \\
11-10 \\
12-10 \\
12-11 \\
13-2 \\
13-0 \\
13-1 \\
14-4 \\
14-4 \\
13-9 \\
14-10 \\
15-5 \\
14-11 \\
15-5 \\
15-5 \\
14-9\end{array}$ & $\begin{array}{l}6-47 \\
6-04 \\
6-57 \\
5-50 \\
5-41 \\
6-33 \\
5-02 \\
6-02 \\
7-48 \\
5-42 \\
6-03 \\
6-22 \\
5-02 \\
5-48 \\
3-43 \\
6-53 \\
5-26 \\
7-45 \\
4-42\end{array}$ & $\begin{array}{l}4 \\
1 \\
2 \\
14 \\
10 \\
2 \\
12 \\
1 \\
12 \\
18 \\
13 \\
40 \\
0 \\
7 \\
19 \\
24 \\
5 \\
2 \\
3\end{array}$ & $\begin{array}{l}13 \\
16 \\
14 \\
14 \\
15 \\
14 \\
17 \\
16 \\
11 \\
14 \\
14 \\
9 \\
19 \\
15 \\
21 \\
10 \\
17 \\
12 \\
00\end{array}$ & $\begin{array}{l}5-52 \\
5-40 \\
5-23 \\
5-52 \\
5-01 \\
5-20 \\
5-33 \\
5-38 \\
6-16 \\
6-25 \\
6-21 \\
5-54 \\
4-08 \\
5-04 \\
3-37 \\
6-34 \\
4-22 \\
5-49 \\
4-20\end{array}$ & $\begin{array}{l}7 \\
4 \\
4 \\
6 \\
5 \\
1 \\
1 \\
1 \\
2 \\
1 \\
9 \\
4 \\
3 \\
2 \\
4 \\
4 \\
5 \\
1 \\
4\end{array}$ \\
\hline MoFee: Maxime & $14-7$ & $8-18$ & 8 & 11 & $6-06$ & \\
\hline
\end{tabular}


IEGROO GIRLS

Trial I Seventh Grade

Name Jones lapgie 16-0 Time Robinson. Iida 15-7 Crosswhite . B. 16-8 Beverly. Georfial6-7 Vincent,I1111an 17-11 6-16

$\begin{array}{lcr}\text { Error } & \text { ir.P.1. } & - \text { Time } \\ 11 & 14 & 5-57 \\ 4 & 12 & 6-48 \\ 4 & 23 & 3-29 \\ 27 & 11 & 5-20 \\ 2 & 15 & 5-35\end{array}$

First Year High School

\begin{tabular}{|c|c|c|c|c|c|c|}
\hline 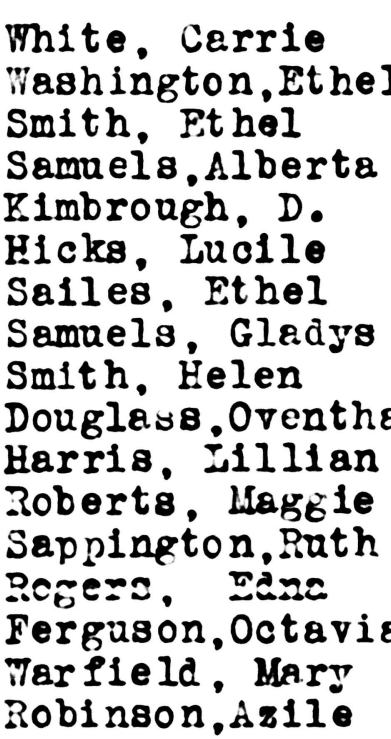 & $\begin{array}{l}13-9 \\
113-10 \\
13-8 \\
13-6 \\
13-2 \\
13-11 \\
14-2 \\
14-6 \\
14-6 \\
215-4 \\
15-0 \\
15-0 \\
15-11 \\
16-2 \\
16-0 \\
17-10 \\
17-6\end{array}$ & $\begin{array}{l}7-51 \\
5-35 \\
5-54 \\
5-24 \\
5-38 \\
5-20 \\
7-31 \\
5-30 \\
6-26 \\
6-13 \\
6-06 \\
5-01 \\
4-34 \\
5-24 \\
6-19 \\
3-49 \\
7-04\end{array}$ & $\begin{array}{l}17 \\
10 \\
15 \\
15 \\
22 \\
15 \\
7 \\
11 \\
15 \\
6 \\
11 \\
11 \\
18 \\
4 \\
18 \\
35 \\
25\end{array}$ & $\begin{array}{l}10 \\
15 \\
14 \\
15 \\
13 \\
15 \\
12 \\
15 \\
13 \\
14 \\
14 \\
17 \\
17 \\
17 \\
12 \\
16 \\
10\end{array}$ & $\begin{array}{l}4-39 \\
4-22 \\
5-24 \\
5-09 \\
4-52 \\
5-59 \\
6-25 \\
5-09 \\
6-36 \\
6-02 \\
5-09 \\
4-55 \\
3-56 \\
5-24 \\
5-18 \\
3-53 \\
6-02\end{array}$ & $\begin{array}{l}21 \\
8 \\
8 \\
5 \\
23 \\
14 \\
8 \\
6 \\
11 \\
7 \\
10 \\
0 \\
0 \\
6 \\
4 \\
18 \\
16\end{array}$ \\
\hline
\end{tabular}

Second Year High Sohool

\begin{tabular}{|c|c|c|c|c|c|c|}
\hline 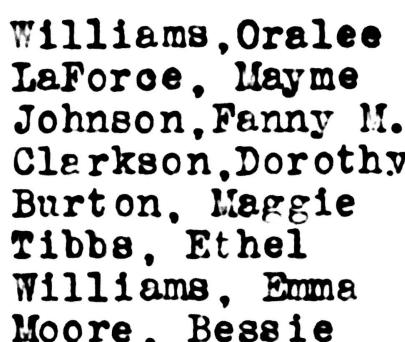 & $\begin{array}{l}14-9 \\
14-8 \\
14-5 \\
14-10 \\
14-0 \\
15-6 \\
15-8 \\
18-2\end{array}$ & $\begin{array}{l}7-16 \\
5-04 \\
6-41 \\
4-31 \\
6-48 \\
5-23 \\
6-53 \\
4-49\end{array}$ & $\begin{array}{l}30 \\
5 \\
1 \\
6 \\
19 \\
18 \\
4 \\
23\end{array}$ & $\begin{array}{l}9 \\
18 \\
14 \\
20 \\
11 \\
14 \\
13 \\
15\end{array}$ & $\begin{array}{l}5-23 \\
5-26 \\
5-14 \\
5-46 \\
5-51 \\
5-28 \\
6-14 \\
5-38\end{array}$ & $\begin{array}{l}10 \\
6 \\
2 \\
2 \\
6 \\
11 \\
8 \\
16\end{array}$ \\
\hline
\end{tabular}

Third Year High School

$\begin{array}{llllllll}\text { G1lmore,Pauline } & 15-8 & 6-12 & 11 & 14 & 5-09 & 2 & 18 \\ \text { Lewis. Biola } & 16-3 & 5-15 & 14 & 16 & 4-58 & 7 & 18 \\ \text { Smith, Rub } & 16-8 & 5-26 & 27 & 13 & 5-40 & 25 & 12 \\ \text { Tashington, B. } & 16-5 & 4-56 & 19 & 16 & 4-50 & 10 & 18 \\ \text { Roberts. Batie } & 17-3 & 5-40 & 15 & 14 & 5-25 & 0 & 18 \\ \text { Foster. Retha } & 17-2 & 4-35 & 22 & 16 & 4-14 & 11 & 20\end{array}$


WHITE GIRIS

60

Trial I

Name

Bahm. Iala

Jullette. Gordon

Fay, Dorothy

Trimble. Tinnie

Reed Mary

MoMilien, Cleo

Crosswhite. Vera

Brady. llartha

Wright . Evalina

Mcallister, vula

Pajne. Irene

Alvis. Sybil

Hulen, Hargeret

Melvin, Ella

Fyat. Lucile

Whitesides, Elole

Gooding. Ruby

Bant a. Elrnth

Finley, Virginia

iroker, 0l1ve

Thi tesides, llaurine

7oods, Florence 10-10

Whitesides, Bxie 10-9

Nichols. Pearl 10-5

Boutwell, Buelah 10-0

Ballenger, Sigmund

Hockbee. Katie

Jones, Edith

Nigeint on. Thelma

MoCown. llartha

Jacobs, Janette

Noe 1, Glady 8

Sims, Marion

Gravitt. Eunice

Gladwili, Mary

Fenton, Nellie

$9-10$

$10-4$

$11-10$

$11-9$
Fourth Grade$$
\text { A }
$$

Age Time Errors $\mathrm{H} . \mathrm{P} . \mathrm{H}=-\mathrm{Time}$

$9-11 \quad 5-22 \quad 6 \quad 17 \quad 5-25$

$9-6 \quad 6-48$

5-05

$6 \quad 13$

5-10

4-55

5-18

$9-10 \quad 5-55$

14

15

$7-07$

5-47

$4-43$

4-02

$4-17$

5-00

5-40

$6-41$

$5-00$

$4-32$

$\begin{array}{llll}16 & 4-07 & 4 & 22\end{array}$

$6-42$

$5-45$

$5-44$

$5-40$

rrors H.P.N.

$11 \quad 16$

916

$9 \quad 17$

$17 \quad 16$

$7 \quad 17$

413

416

320

622

322

$7 \quad 18$

316

414

4
.18

$10-7 \quad 4-53$

17

16

17

10-10 8-11

411

$10 \quad 15$

$21 \quad 14$

II

13

$11 \quad 18$

4-44 11

4-35

20

$5-20$

10

5-51

9

16

15

5-54

4-37

11

14 .

5-10

$11-10 \quad 5-45$

$11-3 \quad 6-29$

$11-8 \quad 6-43$

$12-11 \quad 7-25$

12-11 5-55

6

19

17

16

$\begin{array}{rr}7 & 14 \\ 15 & 12\end{array}$

612

615

$\begin{array}{llll}12-3 & 7-00 & 8 & 13\end{array}$

$13-11 \quad 4-45$

$13-2$ 6-24

11

19

$4-18$

5-05

5-41

$5-45$

$4-08$

4-18

5-17

6-01

$6-32$

$6-34$

$5-02$

$6-00$

$4-24$

4-34

Fifth Grade

$\begin{array}{lllrlrrr}\text { Grimes, Marian } & 10-5 & 6-42 & 6 & 13 & 7-41 & 4 & 12 \\ \text { Mote. Iola } & 10-4 & 6-21 & 5 & 14 & 5-58 & 0 & 16 \\ \text { Sapp. Rubyr } & 10-10 & 5-56 & 8 & 15 & 5-42 & 3 & 16 \\ \text { Crows. Julia } & 10-10 & 6-38 & 29 & 11 & 6-33 & 19 & 12 \\ \text { Gollaher. Helon } & 10-7 & 5-43 & 4 & 16 & 4-53 & 3 & 19 \\ \text { Garrett. Fostina } & 11-10 & 7-45 & 0 & 12 & 6-35 & 0 & 15 \\ \text { Forb1s. Alpha } & 11-8 & 5-32 & 4 & 17 & 5-30 & 3 & 17 \\ \text { Norreli. Fransis } & 11-4 & 4-10 & 12 & 20 & 4-01 & 2 & 23 \\ \text { Tarner. Kathleen } & 11-3 & 6-18 & 3 & 15 & 7-05 & 9 & 10\end{array}$


Thite Girls

Trial I Pifth Grade $\quad$ Trial II

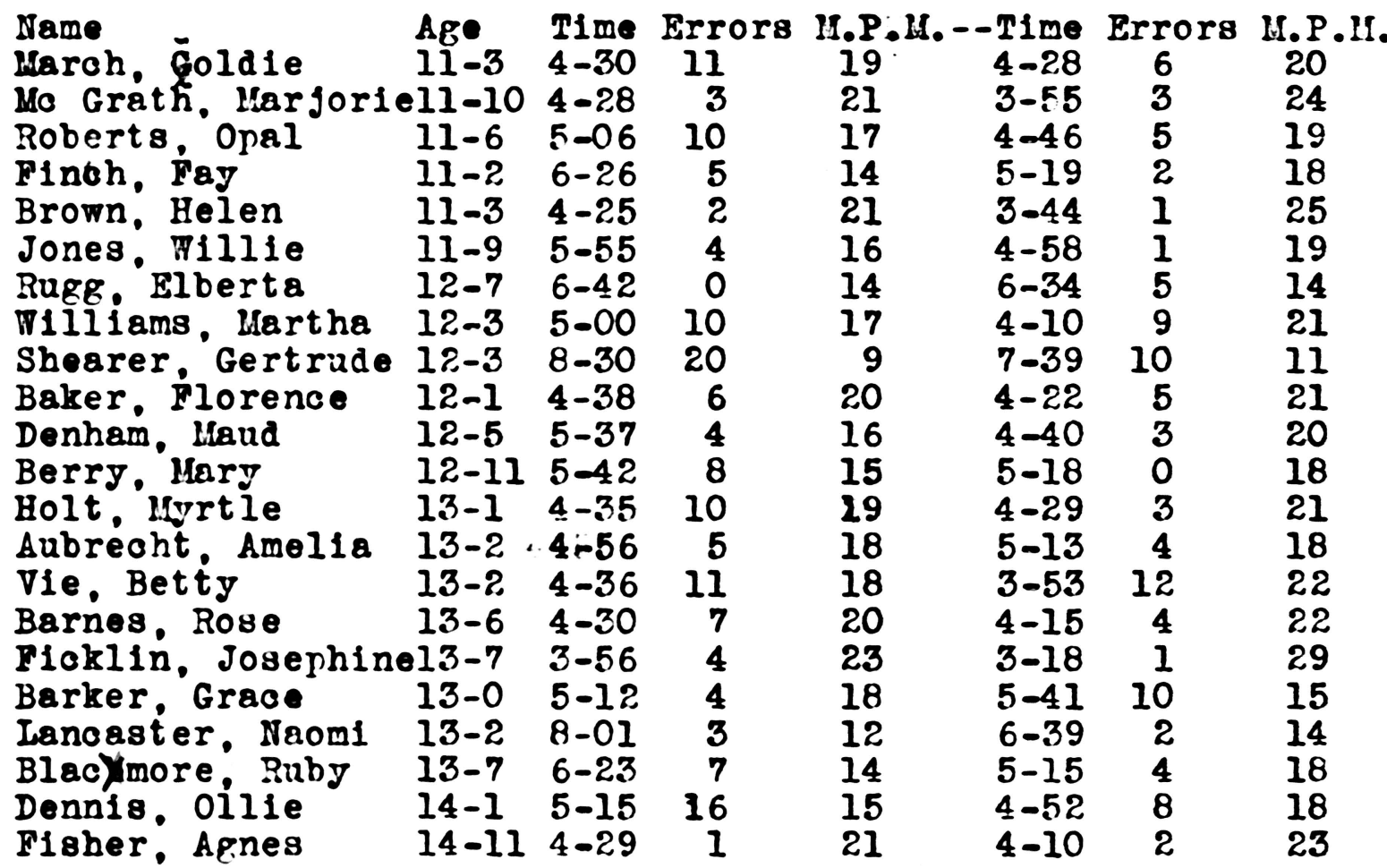

Sixth Grade

\begin{tabular}{|c|c|c|c|c|c|c|}
\hline 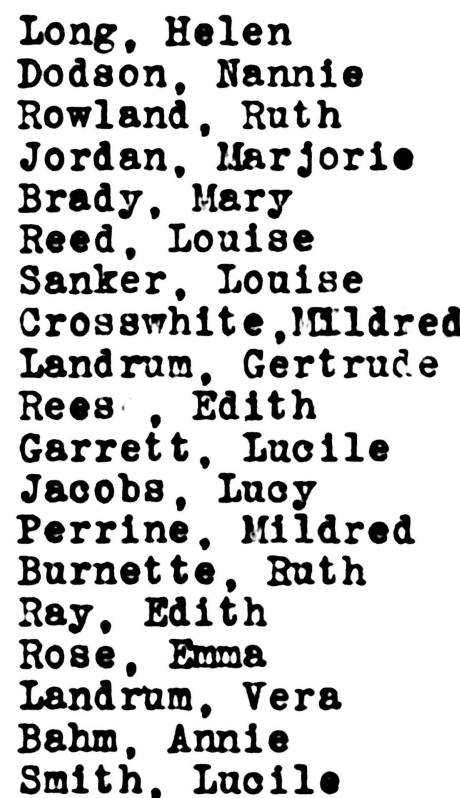 & $\begin{array}{l}11-10 \\
11-8 \\
11-8 \\
11-8 \\
11-6 \\
12-3 \\
12-11 \\
112-2 \\
12-7 \\
13-11 \\
13-11 \\
13-5 \\
13-8 \\
13-4 \\
13-2 \\
13-3 \\
14-8 \\
14-4 \\
16-1\end{array}$ & $\begin{array}{l}5-45 \\
4-27 \\
5-04 \\
4-37 \\
4-37 \\
5-40 \\
7-32 \\
5-10 \\
4-25 \\
4-51 \\
5-35 \\
6-37 \\
6-35 \\
5-28 \\
5-05 \\
4-53 \\
5-40 \\
5-25 \\
4-42\end{array}$ & $\begin{array}{r}6 \\
10 \\
6 \\
4 \\
1 \\
6 \\
2 \\
3 \\
5 \\
3 \\
2 \\
5 \\
6 \\
6 \\
4 \\
2 \\
10 \\
8 \\
3\end{array}$ & $\begin{array}{l}16 \\
19 \\
18 \\
20 \\
21 \\
16 \\
12 \\
18 \\
21 \\
19 \\
17 \\
14 \\
14 \\
17 \\
18 \\
19 \\
15 \\
16 \\
20\end{array}$ & $\begin{array}{l}5-12 \\
4-40 \\
4-11 \\
4-11 \\
4-11 \\
5-14 \\
5-54 \\
4-40 \\
4-32 \\
4-17 \\
5-02 \\
6-05 \\
5-16 \\
4-45 \\
4-42 \\
4-32 \\
5-11 \\
4-54 \\
4-37\end{array}$ & $\begin{array}{r}3 \\
4 \\
1 \\
3 \\
2 \\
1 \\
7 \\
1 \\
5 \\
1 \\
25 \\
1 \\
10 \\
1 \\
1 \\
0\end{array}$ \\
\hline
\end{tabular}

Seventh Grade

$\begin{array}{llllllll}\text { Russel, Florence } 12-1 & 6-10 & 19 & 13 & 5-46 & 2 & 16\end{array}$ Prather, Margueriti2-6 $4-07$ 14 $20 \quad 4-02 \quad 5 \quad 23$ 
Mite Girls

Trial I Seventh Grade Trial II

\begin{tabular}{|c|c|c|c|c|c|c|c|}
\hline 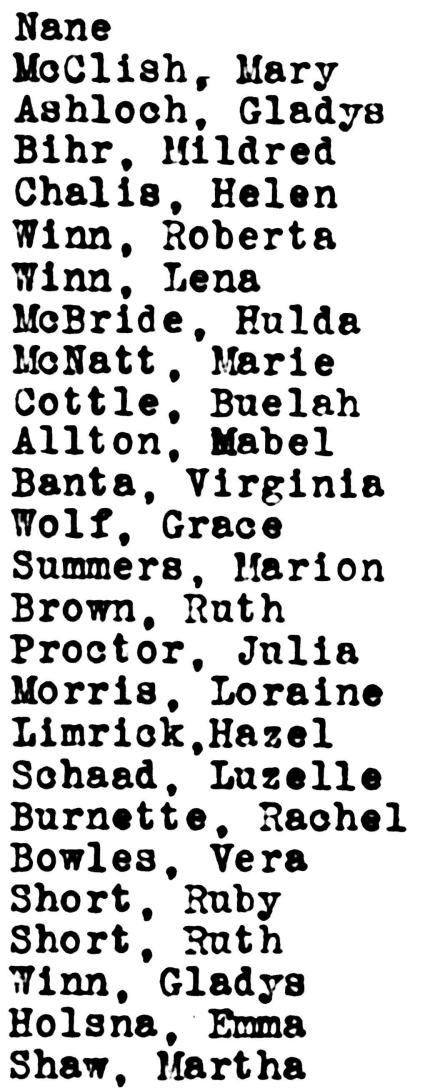 & $\begin{array}{l}\text { AEe } \\
12-11 \\
12-4 \\
12-11 \\
12-4 \\
13-4 \\
13-10 \\
13-5 \\
13-5 \\
13-10 \\
13-8 \\
13-4 \\
13-11 \\
13-2 \\
13-5 \\
13-0 \\
14-7 \\
14-0 \\
14-2 \\
14-5 \\
14-6 \\
15-6\end{array}$ & $\begin{array}{l}\text { Time } \\
5-00 \\
3-48 \\
5-21 \\
5-14 \\
4-00 \\
3-34 \\
5-14 \\
4-18 \\
3-53 \\
4-25 \\
4-36 \\
5-35 \\
5-40 \\
4-47 \\
6-14 \\
4-38 \\
4-13 \\
3-55 \\
3-47 \\
5-12 \\
4-03 \\
5-11 \\
4-36 \\
6-43 \\
3-53\end{array}$ & $\begin{array}{r}\text { Errors } \\
8 \\
19 \\
2 \\
4 \\
3 \\
4 \\
0 \\
1 \\
5 \\
4 \\
7 \\
2 \\
19 \\
5 \\
11 \\
5 \\
6 \\
8 \\
11 \\
16 \\
10 \\
3 \\
9 \\
8 \\
9\end{array}$ & $\begin{array}{c}1 . P \\
18 \\
20 \\
18 \\
18 \\
23 \\
26 \\
18 \\
22 \\
26 \\
21 \\
19 \\
17 \\
14 \\
20 \\
14 \\
20 \\
20 \\
22 \\
22 \\
15 \\
22 \\
18 \\
19 \\
13\end{array}$ & $\begin{array}{l}\text { Time } \\
4-45 \\
3-30 \\
4-52 \\
4-25 \\
4-00 \\
3-07 \\
4-34 \\
4-15 \\
3-40 \\
4-17 \\
4-07 \\
4-32 \\
4-30 \\
4-13 \\
5-60 \\
4-13 \\
5-03 \\
4-00 \\
3-14 \\
4-15 \\
4-12 \\
5-03 \\
4-23 \\
4-47 \\
3-35\end{array}$ & $\begin{array}{l}\text { Errors } \\
5 \\
11 \\
2 \\
7 \\
1 \\
3 \\
2 \\
4 \\
2 \\
1 \\
2 \\
0 \\
4 \\
1 \\
1 \\
5 \\
6 \\
3 \\
3 \\
6 \\
11 \\
2 \\
1 \\
1 \\
4\end{array}$ & $\begin{array}{l}22 \\
23 \\
21 \\
20 \\
23 \\
16 \\
22 \\
18 \\
23 \\
29 \\
21 \\
20\end{array}$ \\
\hline
\end{tabular}

NEGRO BOYS

Fonrth Grade

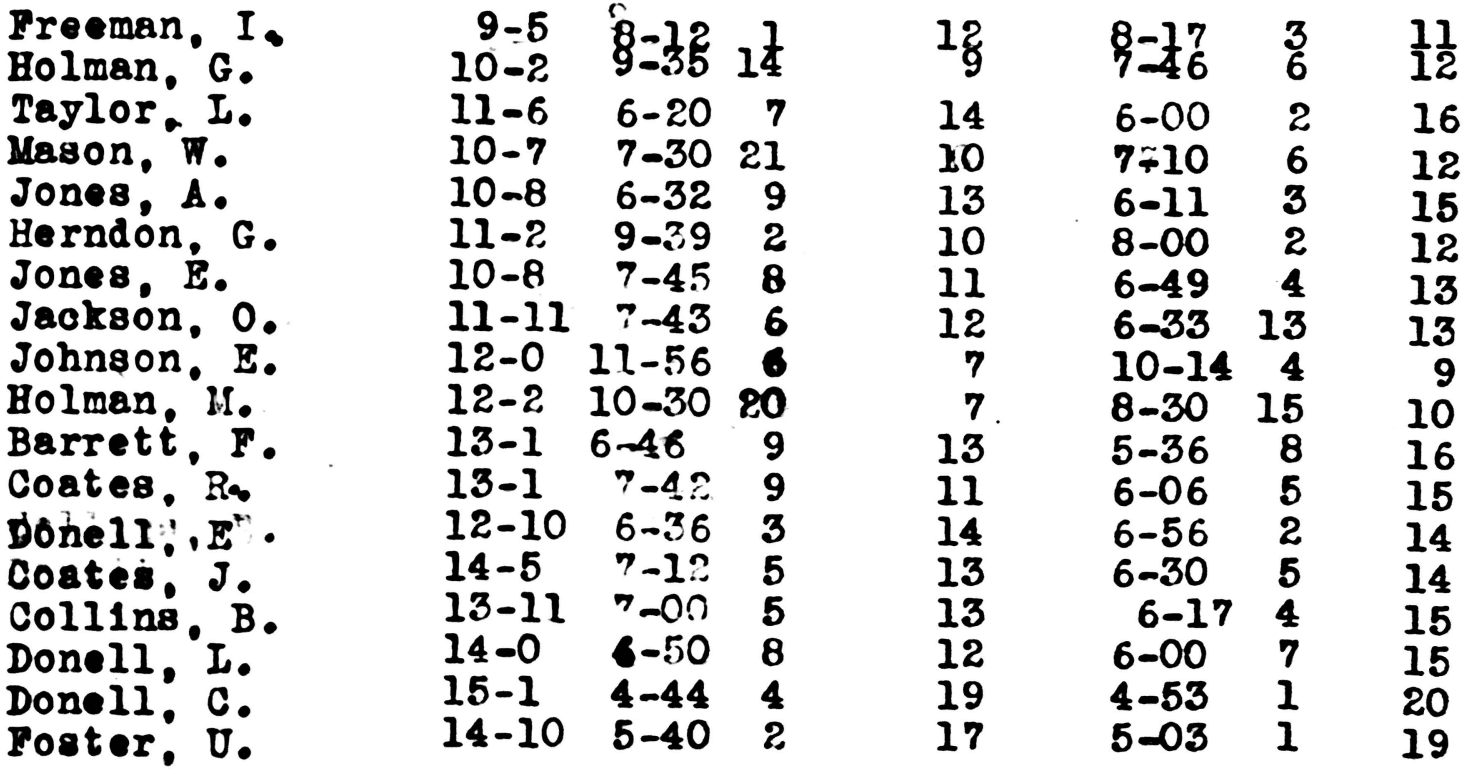


Nogro Boys

Trial I

jiame

Renfro. $\mathrm{K}$.

Brown, $J$

Harr18, R.

Sheley. :

Roberts. $Q$. 11-10

Clark, 0 .

Madison, I.

Postor, $R$.

Clarkson, $R$.

Jonson, $F$.

TIbb8, E.

Campbill. G.

Tashingt on, $\because$.

Robnett G. 13-3

Carter. G. 14-3

Griswoll, G. 13-8

Marshall. I. 13-9

Scott. $\pi^{\circ}$.

Trieg. 0 .

Toods, R.
A

$10-6$
$9-9$

$11-2$

$11-0$

$11-7$

$12-0$

$13-5$

$13-3$

$12-11$

$12-10$

$13-5$

$13-0$

$14-1$

$13-9$

$15-2$
Pifth Grade

¿imo Errors H.P.H. $6-21 \quad 13$ i3

$6-07 \quad 2 \quad 15$

$7-24 \quad 7 \quad 12$

$6-12 \quad 5 \quad 15$

$6-00 \quad 9 \quad 15$

$6-54 \quad 5 \quad 13$

$5-56 \quad 16$

$5-38 \quad 2$

$8-475$

$6-27 \quad 17$

$6-58 \quad 8$

$6-58 \quad 12$

$5-134$

$8-26 \quad 6$

$6-359$

$7-25$

$7-48$

$7-20$

$5-02$

$6-20$
13

17

10

12

13

12

18

11

13

15

12

12

19

Trial II

-Time Errors II.P.M. $\begin{array}{lll}4-40 & 17 & 17\end{array}$

5-07 $2 \quad 18$

$5-58 \quad 5 \quad 15$

$5-14 \quad 2 \quad 18$

$5-48 \quad 2 \quad 16$

$6-26 \quad 4 \quad 14$

5-37 $11 \quad 15$

$6-03 \quad 3 \quad 15$

$5-56 \quad 2 \quad 16$

6-40 $4 \quad 14$

$7-00 \quad 8 \quad 13$

$\begin{array}{lll}6-42 & 8 & 13\end{array}$

5-27 $6 \quad 17$

$7-58 \quad 10 \quad 11$

$6-17 \quad 4 \quad 15$

$5-55 \quad 0 \quad 16$

$6-5911$

$5-40 \quad 4 \quad 16$

$4-14 \quad 2 \quad 22$

$\begin{array}{lll}6-34 & 4 & 15\end{array}$

Sixth Grade

Washingtion, J. 12-6 6-02 2 16

Gatewood. J. I1-9

Carter. B. $\quad 12-0$

Hioks. P. 12-3

Johnson, $12-1$

Patrick. 7. 12-3

Hagheo. V. 13-1

RoleJ. J. 13-3

Shelej. J. $14-5$

voleman, i. 13-8

Gregdry, S. 14-2

Caldweli. S. 15-0

Coleman, G. 16-2

Tilliams, S. 16-9

Haggard. $\mathrm{H}$. 16-8

Carter. ?.

$17-8$

$\begin{array}{lll}7-27 & 7 & 12\end{array}$

$\begin{array}{lll}7-17 & 8 & 12\end{array}$

$9-09 \quad 6 \quad 10$

$6-398 \quad 13$

$8-22 \quad 4$

11

$6-17 \quad 11$

14

$6-44 \quad 25$

11

$6-45 \quad 13$

12

$6-30 \quad 9$

13

$7-\div 3 \quad 14$

11

6-51 8

13

4-5.0 8

18

$6-06$

14

4-28 $5 \quad 20$

15

$\begin{array}{rrr}5-53 & 5 & 15 \\ 6-36 & 7 & 13 \\ 6-27 & 0 & 15 \\ 1 Q-00 & 1 & 10 \\ 6-09 & 2 & 15 \\ 5-55 & 7 & 15 \\ 5-48 & 4 & 16 \\ 5-31 & 24 & 13 \\ 6-11 & 2 & 15 \\ 5-47 & 0 & 16 \\ 5-58 & 2 & 16 \\ 5-57 & 6 & 15 \\ 4-14 & 1 & 22 \\ 4-25 & 1 & 21 \\ 4-47 & 6 & 19 \\ 5-14 & 2 & 18\end{array}$

Serenth Grade

$\begin{array}{lrrrrrrr}\text { Robnett. M. } & 12-0 & 6-28 & 10 & 13 & 5-47 & 4 & 16 \\ \text { Preeman. J. } & 16-4 & 6-36 & 8 & 13 & 4-49 & 6 & 19 \\ \text { ShelbJ. E. } & 16-6 & & & & & & \\ \text { Rlohardson. J. } & 16-0 & 6-25 & 22 & 12 & 4-41 & 5 & 19\end{array}$


Negro Borg

TRIaI 1

Name

Iogan. 7 .

Carter. E.

T1111ams, J

Wilson, H.

Bent on, $C$.

Reeres. G.

Baker. II.

Porter. J.
Pirst

Sooond Year HIgh Sohool

$\begin{array}{lrrrrrrr}\text { Huese, G. } & 13-9 & 5-58 & 8 & 15 & 5-25 & 1 & 18 \\ \text { Plpes: I. } & 15-2 & 5-27 & 3 & 17 & 5-54 & 3 & 16 \\ \text { Turner. W. } & 15-7 & 5-02 & 9 & 17 & 4-32 & 15 & 18 \\ \text { Huese, } \mathrm{H} . & 16-6 & 4-25 & 14 & 19 & 3-40 & 13 & 23\end{array}$

Third Year High School

$\begin{array}{llllllll}\text { Russel. D. } & 18-2 & 5-24 & 21 & 14 & 4-27 & 12 & 19 \\ \text { Harshsil. R. } & 16-8 & 4-37 & 14 & 18 & 4-06 & 11 & 21\end{array}$

\section{WHITE BOYS}

Pourth Grade

\begin{tabular}{|c|c|c|c|c|c|c|}
\hline 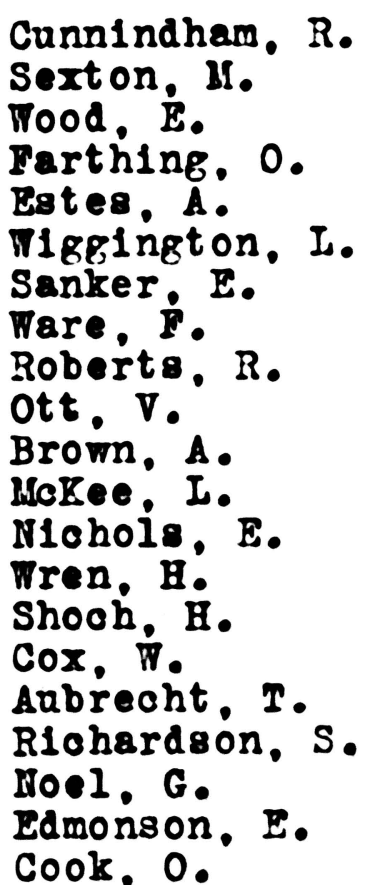 & $\begin{array}{l}9-6 \\
19-10 \\
10-1 \\
10-0 \\
10-7 \\
10-9 \\
10-9 \\
10-3 \\
11-2 \\
11-11 \\
11-8 \\
11-5 \\
11-6 \\
12-2 \\
9-11 \\
10-5 \\
11-7 \\
11-2 \\
11-6 \\
13-2 \\
14-5\end{array}$ & $\begin{array}{l}4-52 \\
6-37 \\
5-25 \\
6-35 \\
6-22 \\
6-48 \\
6-02 \\
6-40 \\
5-01 \\
5-51 \\
6-37 \\
7-06 \\
5-45 \\
7-53 \\
6-17 \\
6-47 \\
6-18 \\
4-46 \\
6-37 \\
6-05 \\
5-45\end{array}$ & $\begin{array}{r}2 \\
1 \\
2 \\
2 \\
12 \\
3 \\
5 \\
19 \\
3 \\
5 \\
6 \\
3 \\
5 \\
13 \\
5 \\
4 \\
7 \\
2 \\
8 \\
4 \\
12\end{array}$ & $\begin{array}{l}20 \\
14 \\
17 \\
14 \\
13 \\
14 \\
15 \\
12 \\
19 \\
16 \\
14 \\
13 \\
16 \\
10 \\
14 \\
14 \\
14 \\
20 \\
13 \\
15 \\
15\end{array}$ & $\begin{array}{l}4-30 \\
6-03 \\
4-64 \\
6-09 \\
6-35 \\
6-44 \\
5-30 \\
5-35 \\
4-24 \\
4-32 \\
6-02 \\
6-04 \\
5-37 \\
6-59 \\
5-34 \\
5-50 \\
5-26 \\
4-11 \\
5-21 \\
5-47 \\
6-08\end{array}$ & $\begin{array}{r}3 \\
2 \\
3 \\
2 \\
4 \\
2 \\
2 \\
20 \\
1 \\
2 \\
5 \\
3 \\
11 \\
4 \\
5 \\
4 \\
5 \\
0 \\
7 \\
9 \\
11\end{array}$ \\
\hline
\end{tabular}


White Boys

Trial I

Name

Ploklin, $C$.

Purdy. I.

King. R.

Barnes. T.

Graff. G.

Anderson, 0 .

Batterton. C.

Bishop. J.

Vandiver. $R$.

Roberts . C.

Miler. E.

WcComn, T.

shearer, G.

Carey. D.

Fifth Grade

Trial II

$\begin{array}{lrrrrrr}\text { Age } & \text { Time } & \text { Errors } & \text { H.P.H. } & - \text { Time } & \text { Frrors } & \text { M.P.M. } \\ 10-8 & 6-20 & 10 & 14 & 6-22 & 3 & 15 \\ 11-3 & 4-42 & 3 & 20 & 3-56 & 2 & 24 \\ 11-11 & 5-42 & 11 & 15 & 5-25 & 1 & 18 \\ 11-0 & 7-52 & 3 & 12 & 6-30 & 2 & 14 \\ 11-11 & 4-40 & 8 & 19 & 4-35 & 8 & 19 \\ 12-9 & 5-05 & 11 & 17 & 4-10 & 2 & 23 \\ 12-8 & 7-00 & 17 & 11 & 6-20 & 3 & 15 \\ 12-7 & 7-10 & 8 & 12 & 6-20 & 0 & 15 \\ 12-4 & 5-35 & 15 & 15 & 5-30 & 10 & 16 \\ 12-1 & 5-16 & 3 & 18 & 5-01 & 4 & 18 \\ 13-11 & 3-55 & 9 & 22 & 3-51 & 2 & 24 \\ 13-2 & 5-30 & 8 & 16 & 5-45 & 9 & 15 \\ 14-10 & 7-25 & 8 & 12 & 6-22 & 8 & 14 \\ 14-1 & 7-38 & 13 & 11 & 6-38 & 4 & 14 \\ 14-5 & 6-15 & 10 & 14 & 5-12 & 7 & 17\end{array}$

Sixth Grade

\begin{tabular}{|c|c|c|c|c|c|c|}
\hline 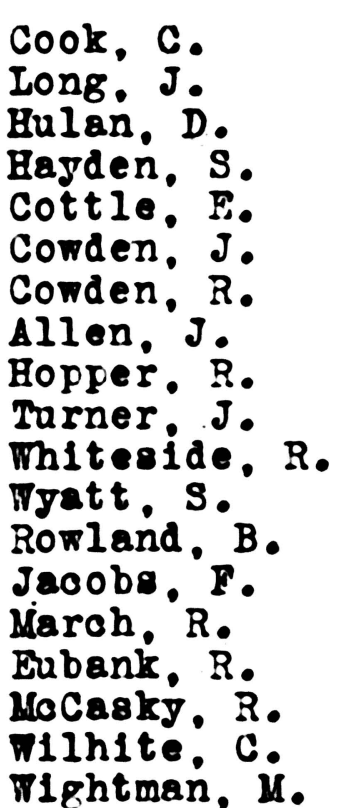 & $\begin{array}{l}11-4 \\
11-8 \\
12-10 \\
12-10 \\
12-6 \\
12-5 \\
12-11 \\
12-0 \\
12-7 \\
12-1 \\
13-2 \\
13-11 \\
13-6 \\
13-3 \\
13-5 \\
14-2 \\
15-3 \\
15-3 \\
15-4\end{array}$ & $\begin{array}{l}4-59 \\
6-09 \\
4-59 \\
6-00 \\
4-59 \\
6-08 \\
5-55 \\
4-40 \\
6-05 \\
5-10 \\
5-09 \\
5-00 \\
4-50 \\
7-04 \\
4-45 \\
4-35 \\
4-59 \\
3-40 \\
4-30\end{array}$ & $\begin{array}{r}11 \\
2 \\
5 \\
1 \\
1 \\
5 \\
16 \\
3 \\
5 \\
4 \\
4 \\
9 \\
4 \\
4 \\
1 \\
6 \\
2 \\
14 \\
12\end{array}$ & $\begin{array}{l}17 \\
15 \\
18 \\
16 \\
19 \\
15 \\
14 \\
20 \\
15 \\
18 \\
18 \\
17 \\
19 \\
13 \\
20 \\
20 \\
19 \\
22 \\
19\end{array}$ & $\begin{array}{l}4-57 \\
5-45 \\
4-48 \\
4-54 \\
4-41 \\
6-22 \\
5-58 \\
4-26 \\
5-16 \\
4-14 \\
4-38 \\
4-35 \\
4-15 \\
6-15 \\
4-35 \\
4-30 \\
5-01 \\
3-28 \\
4-27\end{array}$ & $\begin{array}{r}15 \\
5 \\
3 \\
1 \\
4 \\
3 \\
19 \\
3 \\
2 \\
3 \\
6 \\
8 \\
0 \\
1 \\
3 \\
7 \\
24 \\
2 \\
10\end{array}$ \\
\hline
\end{tabular}

Serenth Grade

$\begin{array}{llllllll}\text { Sappingtion. R. } 11-11 & 4-30 & 4 & 20 & 4-47 & 2 & 19 \\ \text { Bughes. A. } & 12-10 & 4-25 & 5 & 20 & 5-56 & 8 & 22 \\ \text { Armotrong. F. } & 12-3 & 6-30 & 3 & 14 & 5-40 & 3 & 16 \\ \text { Rusael. G. } & 12-2 & 5-30 & 6 & 16 & 4-50 & 7 & 18 \\ \text { Crouch. R. } & 12-3 & 4-25 & 4 & 21 & 3-51 & 4 & 24 \\ \text { Tindali, A. } & 13-1 & 6-20 & 5 & 14 & 5-15 & 7 & 17 \\ \text { MoGa1re. H. } & 13-2 & 5-10 & 2 & 18 & 5-00 & 5 & 18\end{array}$




\section{Trial I Seventh Grade Trial II}

\begin{tabular}{|c|c|c|c|c|c|c|c|}
\hline 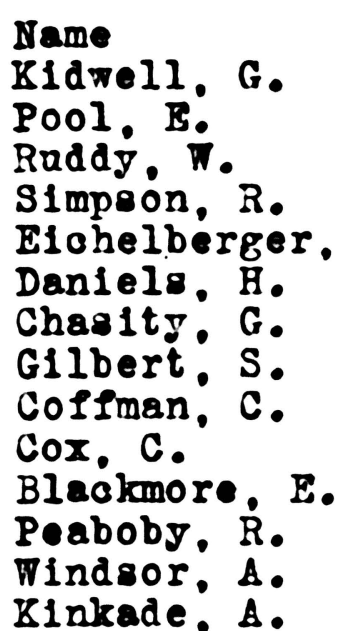 & $\begin{array}{c}180 \\
13-0 \\
13-1 \\
13-6 \\
13-3 \\
114-7 \\
14-0 \\
14-4 \\
14-5 \\
15-1 \\
15-3 \\
15-2 \\
15-11 \\
16-1\end{array}$ & $\begin{array}{l}\text { Time } \\
4-39 \\
4-53 \\
5-10 \\
4-30 \\
5-20 \\
4-45 \\
6-30 \\
4-50 \\
4-14 \\
4-15 \\
7-30 \\
5-38 \\
4-50 \\
4-14\end{array}$ & $\begin{array}{c}\text { Errol } \\
6 \\
9 \\
4 \\
12 \\
18 \\
3 \\
17 \\
6 \\
2 \\
5 \\
16 \\
0 \\
0 \\
9\end{array}$ & $\begin{array}{l}\text { M.P.I. } \\
19 \\
18 \\
18 \\
19 \\
15 \\
20 \\
12 \\
19 \\
22 \\
21 \\
11 \\
17 \\
20\end{array}$ & $\begin{array}{l}- \text { Time } \\
4-14 \\
4-45 \\
3-40 \\
5-20 \\
5-55 \\
4-10 \\
5-00 \\
4-07 \\
4-01 \\
3-50 \\
5-40 \\
5-25 \\
5-10\end{array}$ & $\begin{array}{c}\text { Errors } \\
9 \\
3 \\
2 \\
3 \\
0 \\
4 \\
5 \\
1 \\
1 \\
6 \\
2 \\
2 \\
2 \\
10\end{array}$ & $\begin{array}{l}\mathbf{H} . \mathbf{P} \\
21 \\
20\end{array}$ \\
\hline
\end{tabular}

$\underline{B}$

Original data for 19 practice dajs of 25 minute periods for 6 subjeots

Negro Girls

Ibg $2 b g \quad 3 b g$

Time Errors M.P.H.-TIme Errors M.P.H.-Time Errors H.P.H.

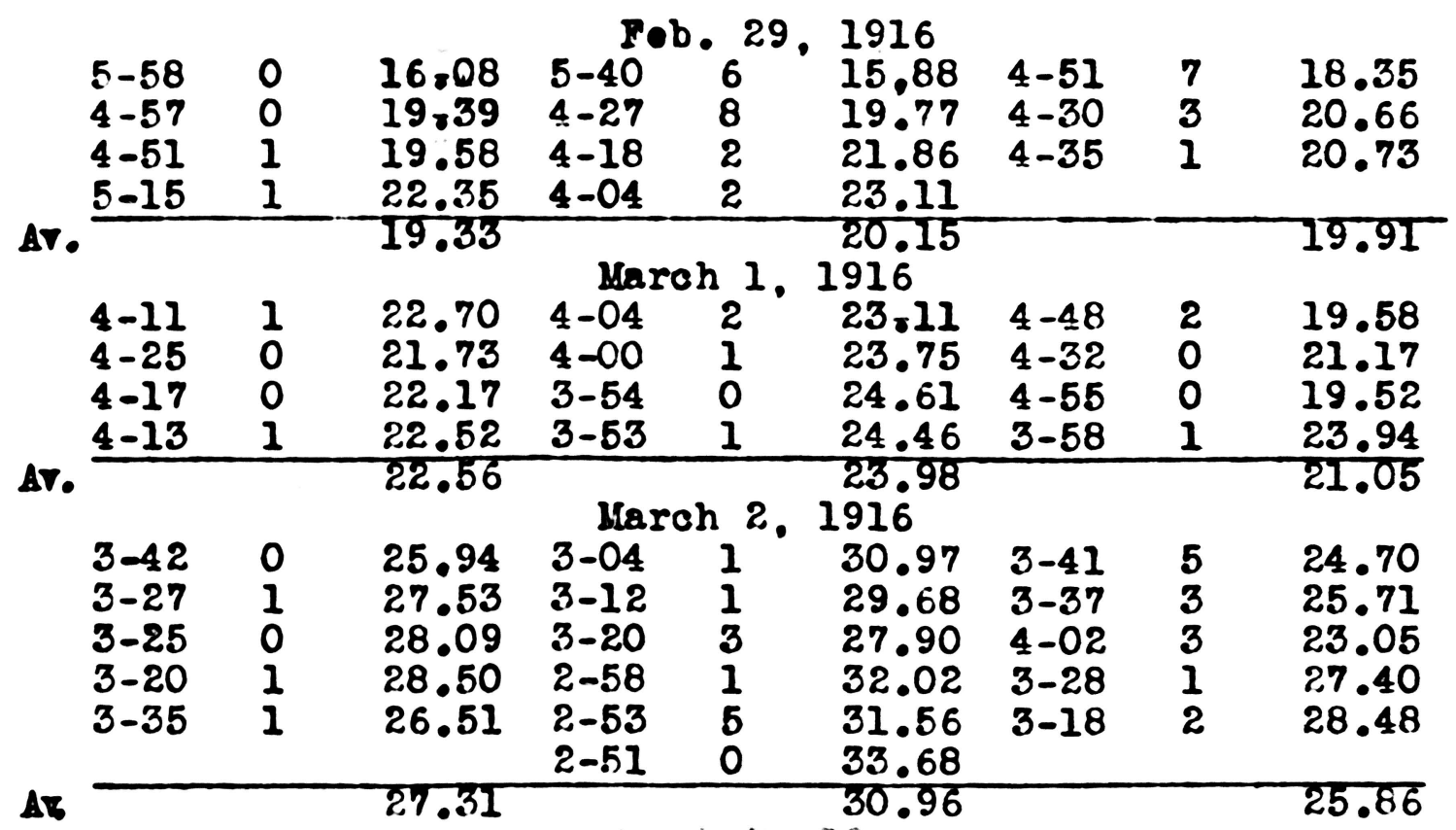


Negro Girls

Ibg

$2 \mathrm{bg}$

$3 \mathrm{bg}$

Time Frrors I.P.H. - Time Errors H.P.H.-TIme Errors H.P.:..

\begin{tabular}{lllllllll} 
& \multicolumn{7}{c}{ Iarch 3.1916} \\
$3-12$ & 0 & 30.00 & $3-07$ & 1 & 30.46 & $3-07$ & 1 & 30.46 \\
$3-15$ & 0 & 29.53 & $3-14$ & 2 & 29.07 & $3-02$ & 3 & 30.65 \\
$3-19$ & 0 & 28.94 & $3-02$ & 1 & 31.31 & $3-02$ & 4 & 30.32 \\
$3-08$ & 0 & 30.64 & $3-17$ & 1 & 28.93 & $2-59$ & 0 & 32.12 \\
$3-21$ & 2 & 28.05 & $3-02$ & 4 & 30.32 & $2-51$ & 0 & 33.68
\end{tabular}

Av.

$\begin{array}{llllll}3-20 & 0 & 28.80 & 2-43 & 2 & 34.60\end{array}$

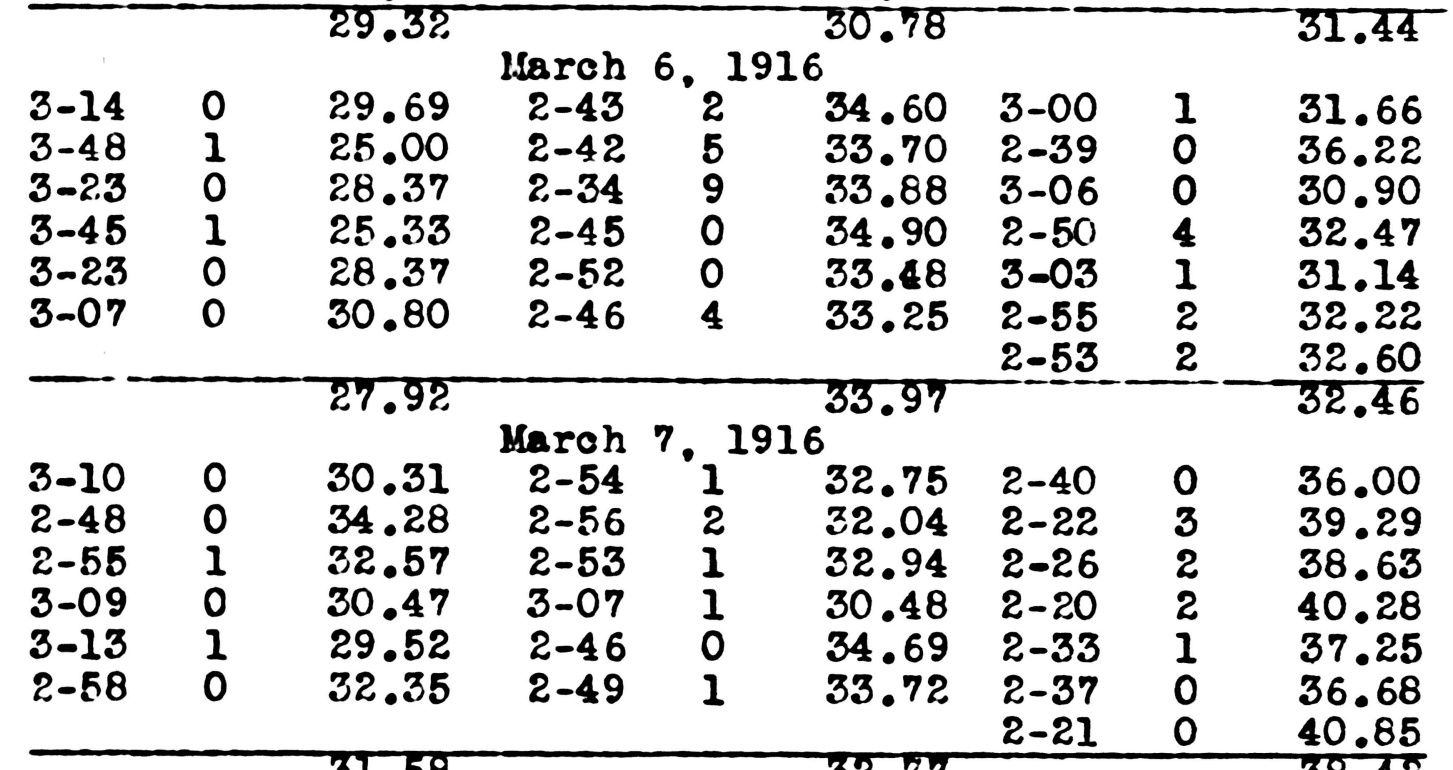

$\Delta \nabla$.

31.58

Ilaroh 8, 1916

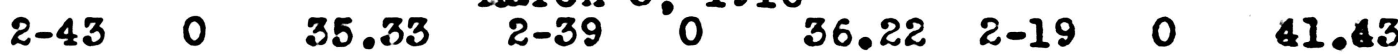

$\begin{array}{lllllllll}2-49 & 0 & 34.08 & 2-43 & 0 & 35.33 & 2-19 & 0 & 41.43\end{array}$

$\begin{array}{lllllllll}2-44 & 0 & 35.12 & 2-50 & 0 & 33.88 & 2-20 & 1 & 40.71\end{array}$

$\begin{array}{lllllllll}2-40 & 0 & 36.00 & 2-52 & 1 & 33.13 & 2-38 & 0 & 36.45\end{array}$

$\begin{array}{lllllllll}2-49 & 0 & 34.08 & 2-53 & 1 & 32.94 & 2-26 & 1 & 39.04\end{array}$

$\begin{array}{lllllllll}2-50 & 0 & 33.88 & 2-47 & 0 & 34.49 & 2-42 & 0 & 35.55\end{array}$

Av.

$2-37 \quad 0 \quad 36.68$

$\begin{array}{llll}36.68 & 2-36 & 0 & 36.92 \\ 35.02 & \end{array}$

$\begin{array}{llllllll}2-30 & 0 & 38.40 & \operatorname{Larch} 9 & 2-30 & 1916 & & \\ 2-38.40 & 2-19 & 0 & 41.43\end{array}$

$\begin{array}{lllllllll}2-38 & 0 & 36.45 & 2-19 & 2 & 40.57 & 2-10 & 0 & 44.30\end{array}$

$\begin{array}{lllllllll}2-35 & 0 & 37.16 & 2-31 & 5 & 36.15 & 2-13 & 2 & 42.42\end{array}$

$\begin{array}{lllllllll}2-27 & 0 & 39.18 & 2-39 & 1 & 35.84 & 2-21 & 1 & 40.42\end{array}$

$\begin{array}{lllllllll}2-33 & 0 & 37.64 & 2-22 & 1 & 40.14 & 2-30 & 2 & 37.60\end{array}$

$\begin{array}{lllllllll}2-35 & 0 & 37.16 & 2-25 & 2 & 38.89 & 2-17 & 0 & 42.04\end{array}$

$\begin{array}{lllllllll}2-32 & 0 & 37.89 & 2-24 & 2 & 39.16 & 2-26 & 0 & 39.45\end{array}$ 
Negro Girls

$1 b g$

$2 \mathrm{bg}$

$3 \mathrm{bg}$

Time Errors I..P.H.-Time Errors H.P.H.-Time Errors H.P.H.

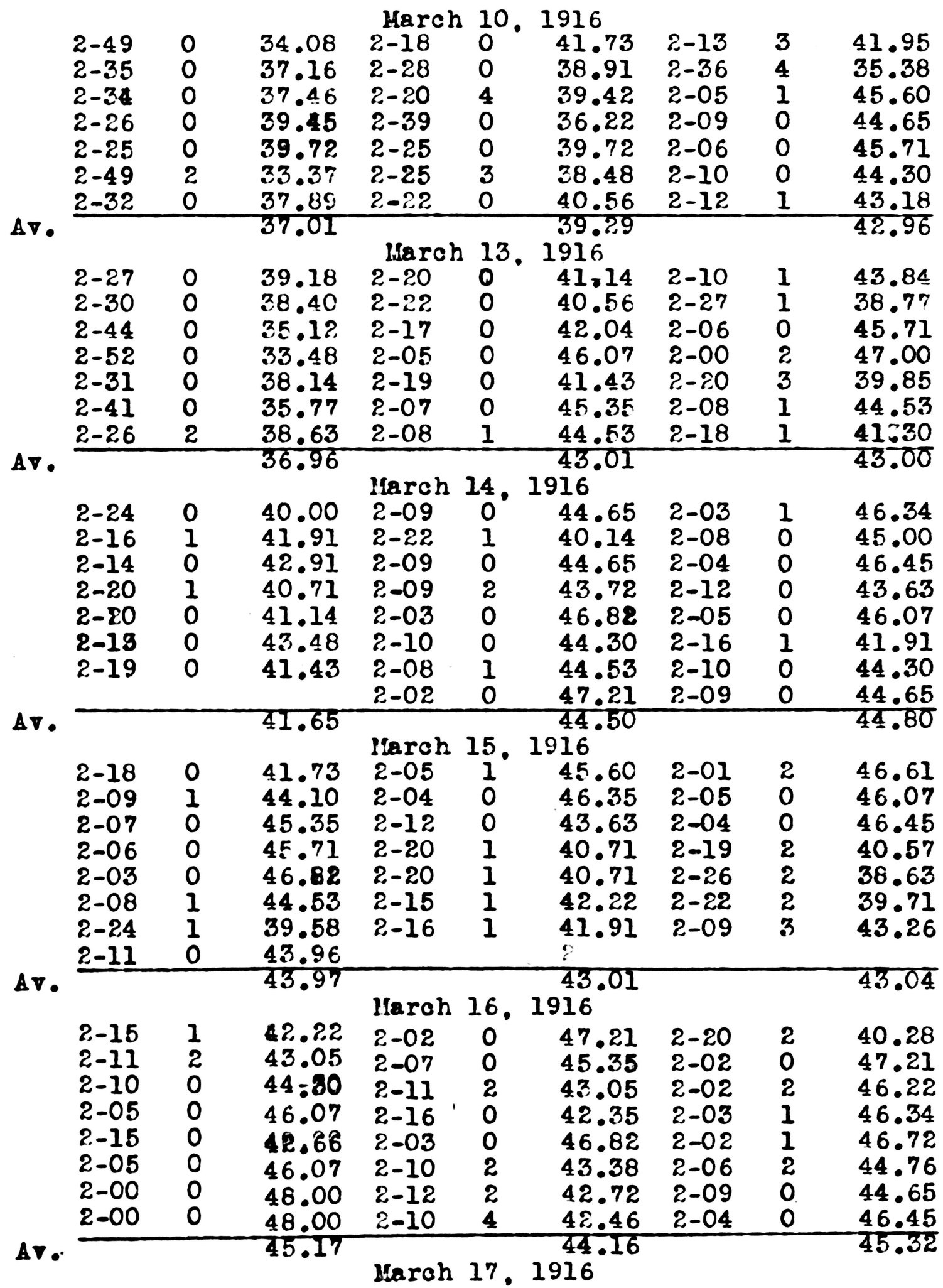


Negro Girls

$1 \mathrm{bg} \quad 2 \mathrm{bg} \quad 3 \mathrm{bg}$

Time Errors H.P.H.-Time Errors H.P.M.-Time Errors H.P.H,

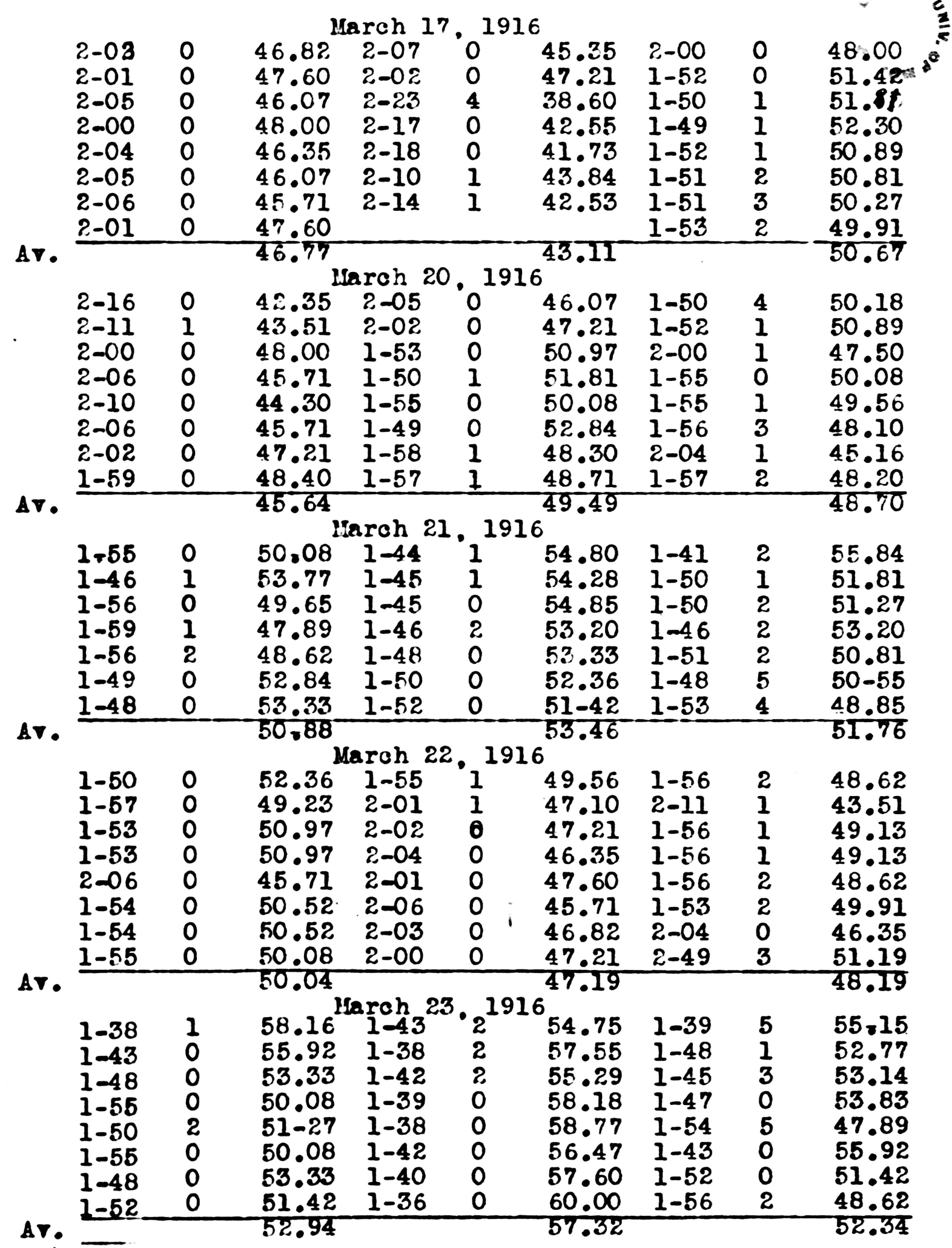


Negro Girls

1 be

$2 \mathrm{bg}$

$3 \mathrm{bg}$

Time Errors H.P.H.-Time Errors H.P.H.-Time Errors M.P.H.

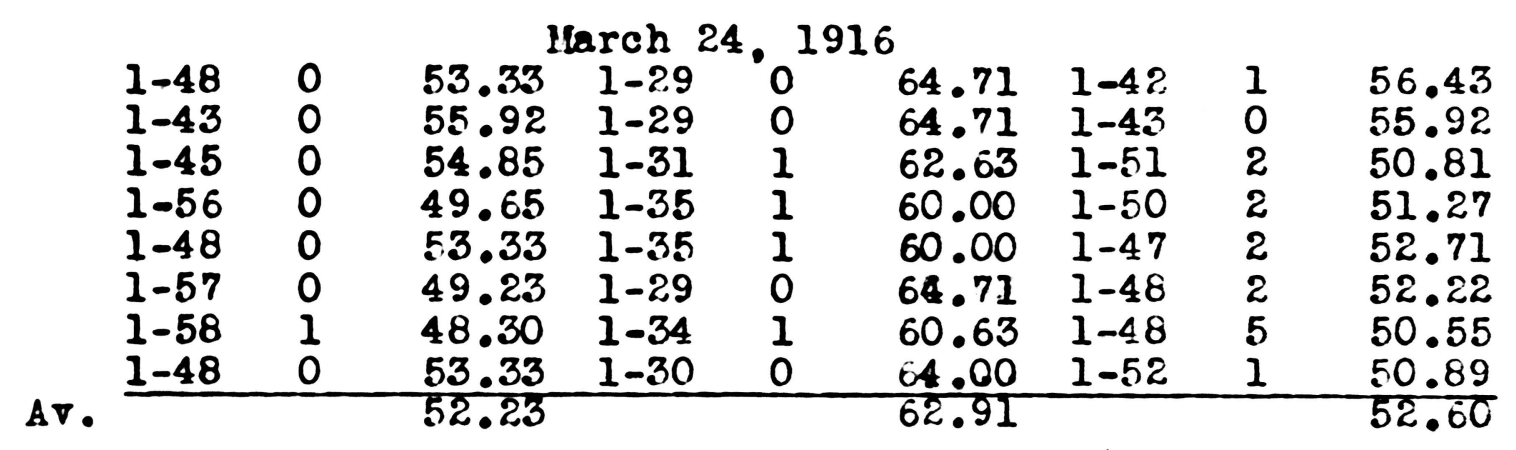

White Girls

$1 \pi g$

$2 \pi g$

3rE

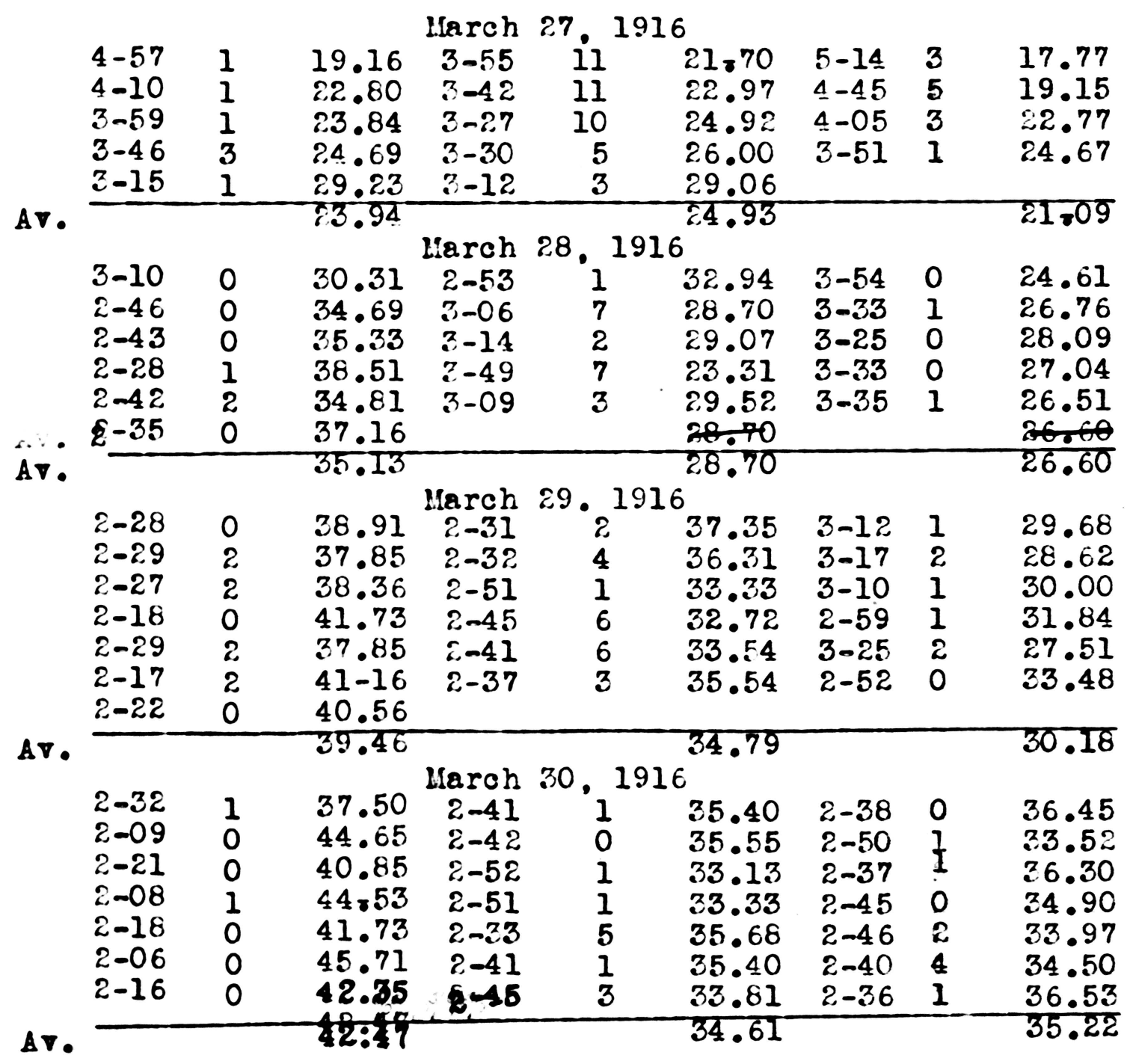


Thite Girls

l\%g

$2 \pi 8$

3wE

Time Errors H.P.M.-TIme Errors M.P.H.-Time Errors H.P.M. llarch 31, 1916

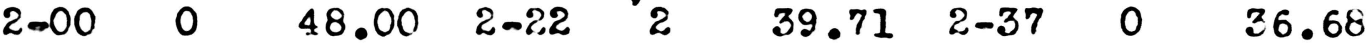

$\begin{array}{lllllllll}1-55 & 0 & 50.08 & 2-17 & 1 & 41.60 & 2-42 & 1 & 35.18\end{array}$

$\begin{array}{lllllllll}2-00 & 0 & 48.00 & 2-31 & 1 & 37.74 & 2-2.9 & 2 & 37.85\end{array}$

$\begin{array}{lllllllll}1-53 & 1 & 50.44 & 2-16 & 0 & 42.35 & 2-28 & 1 & 38.51\end{array}$

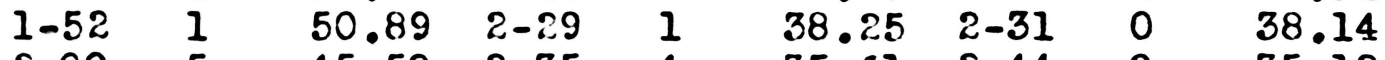

$\begin{array}{lllllllll}2-\infty & 5 & 45.50 & 2-35 & 4 & 35.61 & 2-44 & 0 & 35.12\end{array}$

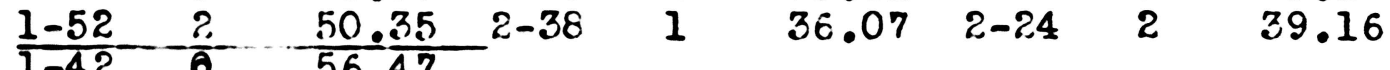

Ar.

$1-42-\frac{50}{6} \quad 56.47$
49.96

38.7637 .23

$\begin{array}{llllllllll}1-53 & 1 & 50.44 & 2-21 & 0 & 40.85 & 2-20 & 1 & 40.71\end{array}$

$\begin{array}{lllllllll}1-57 & 0 & 49.23 & 2-21 & 0 & 40.85 & 2-21 & 2 & 40.00\end{array}$

$\begin{array}{lllllllll}1-46 & 0 & 54.33 & 2-18 & 0 & 41.73 & 2-31 & 1 & 37.74\end{array}$

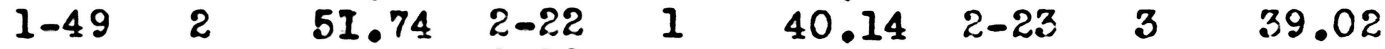

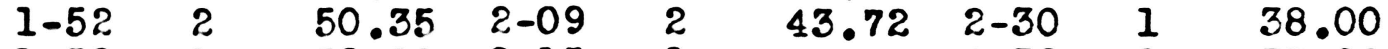

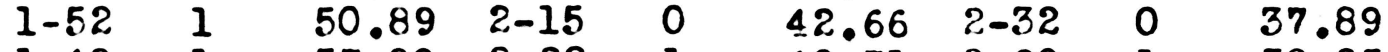

$\begin{array}{lllllllll}1-40 & 1 & 57.00 & 2-20 & 1 & 40.71 & 2-29 & 1 & 38.25\end{array}$

Av.

$\begin{array}{llll}1-531 & 50.44 & 41.52 & 38.80\end{array}$

\begin{tabular}{lllllllll}
\multicolumn{8}{c}{ Apri1 } & \multicolumn{1}{c}{1916} \\
$1-50$ & 1 & 51.81 & $2-21$ & 0 & 40.85 & $2-21$ & 0 & 40.85 \\
$1-49$ & 1 & 52.30 & $2-16$ & 0 & 42.35 & $2-35$ & 2 & 36.38 \\
$1-44$ & 2 & 54.23 & $2-05$ & 1 & 45.60 & $2-32$ & 0 & 37.89 \\
$1-42$ & 0 & 56.47 & $2-04$ & 0 & 46.45 & $2-12$ & 1 & 43.18 \\
$1-49$ & 3 & 51.19 & $2-08$ & 1 & 44.53 & $2-19$ & 1 & 41.00 \\
$1-41$ & 3 & $\mathbf{5 5 . 2 4}$ & $2-17$ & 3 & 40.72 & $2-25$ & 0 & 39.72 \\
$1-43$ & 1 & 55.33 & $2-12$ & 1 & $\mathbf{4 3 . 1 8}$ & $2-30$ & 0 & $\mathbf{3 8 . 4 0}$
\end{tabular}

Av.

\begin{tabular}{lll}
$1-47$ & 1 & 53.27 \\
$1-34$ & 0 & 61.27 \\
\hline
\end{tabular}

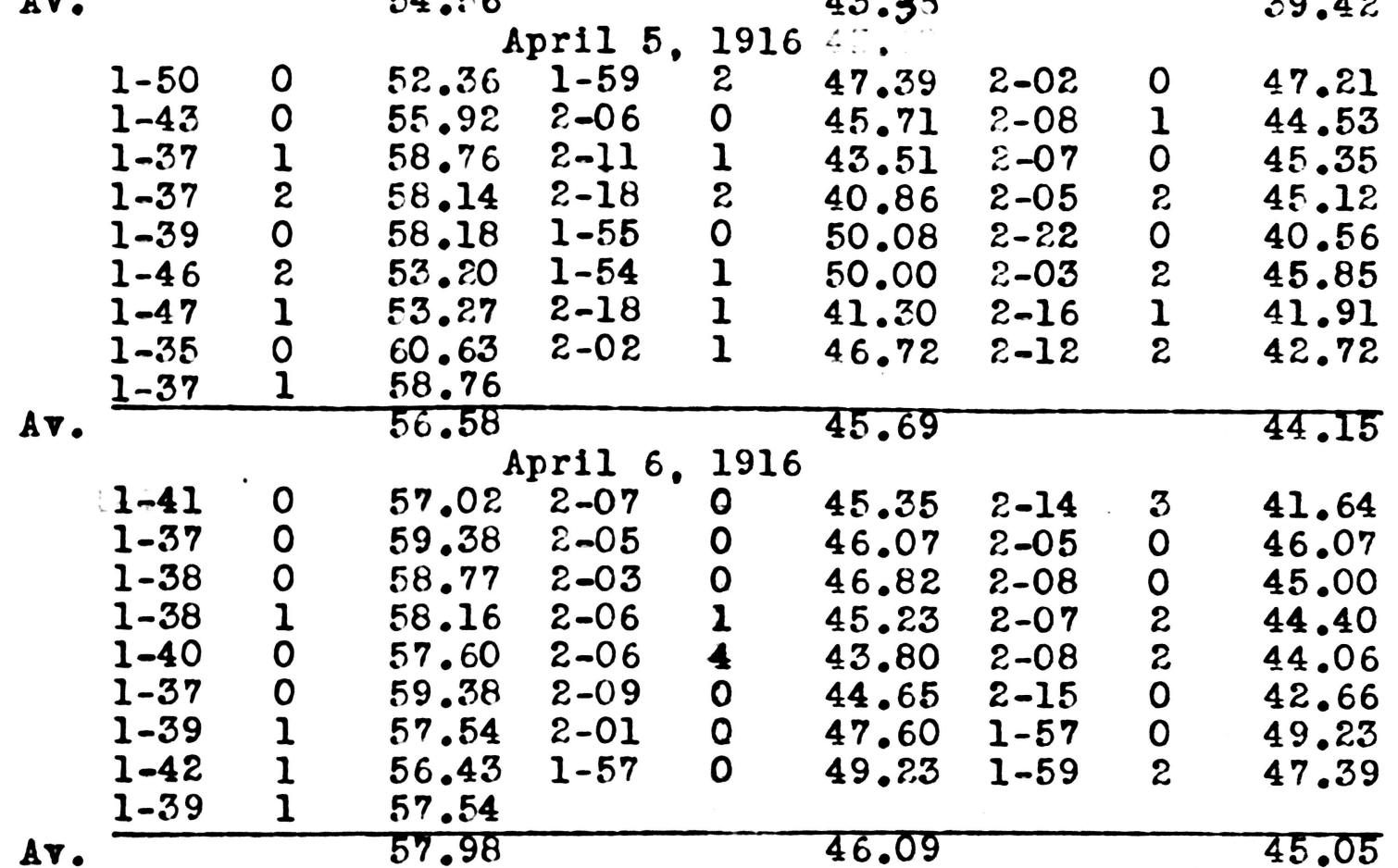


White Girls

lWg

2WE

3 wg

Time Errors 11.P.H.-Time Errors H.P.L.-Time Errors H.P.II. April 7, 1916

$\begin{array}{lllllllll}2-06 & 3 & 44.28 & 2-00 & 4 & 46.00 & 2.00 & 0 & 48.00\end{array}$

$\begin{array}{lllllllll}1-46 & 2 & 53.20 & 2-04 & 0 & 46.45 & 2-07 & 0 & 45.35\end{array}$

$\begin{array}{lllllllll}2-06 & 3 & 44.28 & 2-04 & 1 & 45.96 & 2-01 & 0 & 47.60\end{array}$

$\begin{array}{lllllllll}1-46 & 0 & 54.33 & 2-08 & 2 & 44.06 & 2-00 & 0 & 48.00\end{array}$

$\begin{array}{lllllllll}1-42 & 1 & 56.43 & 1-59 & 1 & 47.89 & 2-05 & 0 & 46.0 \text { ? }\end{array}$

$\begin{array}{lllllllll}1-41 & 1 & 56.43 & 2-09 & 0 & 44.65 & 2-17 & 0 & 42.55\end{array}$

$\begin{array}{lllllllll}1-42 & 0 & 56.47 & 2-01 & 0 & 47.60 & 2-27 & 0 & 39.18\end{array}$

$\begin{array}{lllllllll}1-41 & I & 56.43 & 2-00 & 1 & 47.50 & 2-06 & 1 & 45.23\end{array}$

A.

$1-46 \quad 0 \quad 54.33$

$52.90-46.26 \quad 45.24$

April 10, 1916

$\begin{array}{lllllllll}1-47 & 0 & 53.83 & 2-05 & 1 & 45.60 & 1-59 & 2 & 47.39\end{array}$

$\begin{array}{lllllllll}1-42 & 2 & 55.29 & 1-59 & 0 & 48.40 & 2-06 & 0 & 45.71\end{array}$

$\begin{array}{lllllllll}1-45 & 0 & 54.85 & 2-07 & 1 & 45.98 & 1-59 & 1 & 47.89\end{array}$

$\begin{array}{lllllllll}1-51 & 5 & 49.18 & 2-08 & 1 & 44.53 & 2-10 & 2 & 43.38\end{array}$

$\begin{array}{lllllllll}1-49 & 2 & 51.74 & 2-00 & 1 & 47.50 & 2-09 & 0 & 44.65\end{array}$

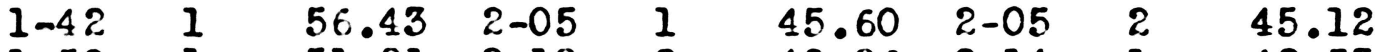

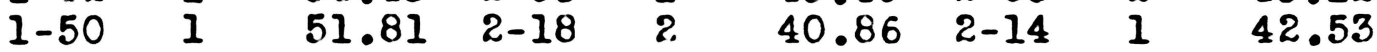

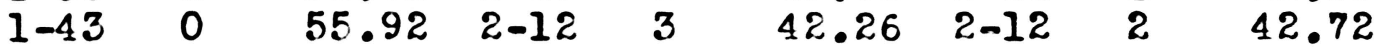

A $\nabla$.

$1-350 \quad 60.63$

$54.40 \quad 45.0924 .92$

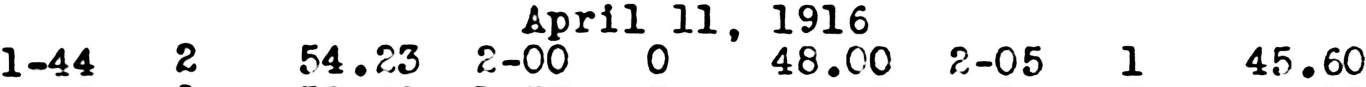

$\begin{array}{lllllllll}1-40 & 0 & 57.60 & 1-57 & 5 & 46.61 & 2-04 & 3 & 45.00\end{array}$

$\begin{array}{lllllllll}1-32 & 0 & 62.60 & 1-53 & 1 & 50.44 & 1-59 & 0 & 48.40\end{array}$

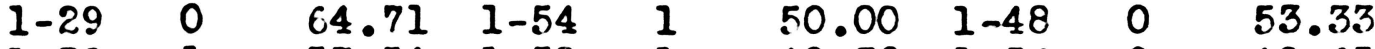

$\begin{array}{lllllllll}1-39 & 1 & 57.54 & 1-58 & 1 & 48.30 & 1-56 & 0 & 49.65\end{array}$

$\begin{array}{lllllllll}1-44 & 2 & 54.23 & 1-54 & 0 & 50.52 & 1-59 & 1 & 47.65\end{array}$

$\begin{array}{lllllllll}1-36 & 1 & 59.37 & 1-51 & 3 & 50.27 & 2-03 & 3 & 45.36\end{array}$

$\begin{array}{lllllllll}1-29 & 0 & 64.71 & 1-48 & 0 & 53.33 & 2-03 & 2 & 45.85\end{array}$

Av •

$1-27 \quad 0 \quad 66.20$

$49.68-47.63$

Apri1 12, 1916

$\begin{array}{lllllllll}1-41 & 0 & 57.02 & 1-41 & 0 & 57.02 & 1-55 & 1 & 49.56\end{array}$

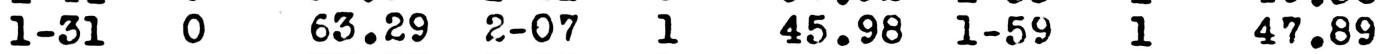

$\begin{array}{lllllllll}1-38 & 2 & 57.55 & 1-53 & 1 & 50.44 & 2-00 & 0 & 48.00\end{array}$

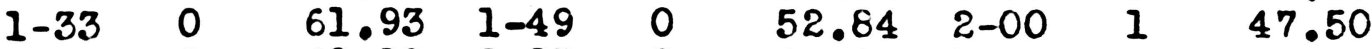

$\begin{array}{lllllllll}1-34 & 2 & 60.00 & 2-03 & 0 & 46.82 & 1-57 & 1 & 48.71\end{array}$

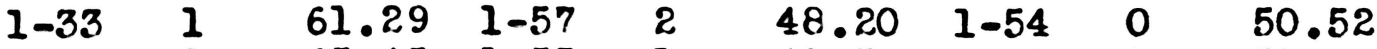

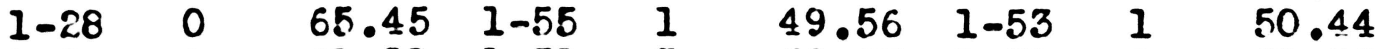

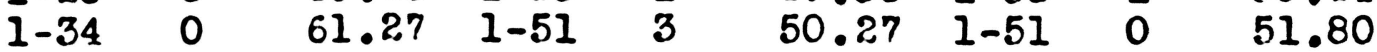

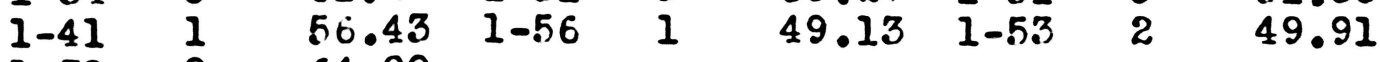

A $\nabla$.

64.00

50.02

49.31 
White Girls

I\%g 2 WRg $\quad 3 w g$

Time Errory II.P.:..-Time Frrors IS.P.If.-Time Errors II.P.II.

\begin{tabular}{|c|c|c|c|c|c|c|c|c|}
\hline $\begin{array}{l}1-40 \\
1-26 \\
1-33 \\
1-29 \\
1-28 \\
1-33 \\
1-29 \\
1-31 \\
1-31\end{array}$ & $\begin{array}{l}2 \\
2 \\
0 \\
0 \\
0 \\
0 \\
1 \\
2 \\
1\end{array}$ & $\begin{array}{l}\quad \text { Ap } \\
56.40 \\
65.58 \\
61.93 \\
64.71 \\
65.45 \\
61.93 \\
64.04 \\
61.97 \\
62.63\end{array}$ & $\begin{array}{l}113 \\
1-53 \\
1-59 \\
1-59 \\
2-00 \\
1-57 \\
1-59 \\
2-05 \\
2-00\end{array}$ & $\begin{array}{c}1916 \\
0 \\
2 \\
0 \\
0 \\
0 \\
4 \\
2 \\
1\end{array}$ & $\begin{array}{l}50.97 \\
47.39 \\
48.40 \\
48.00 \\
49.23 \\
46.38 \\
45.12 \\
47.50\end{array}$ & $\begin{array}{l}1-50 \\
1-55 \\
1-56 \\
1-57 \\
1-46 \\
1-50 \\
1-52 \\
1-54 \\
1-53\end{array}$ & $\begin{array}{l}1 \\
3 \\
1 \\
2 \\
1 \\
1 \\
0 \\
0 \\
0\end{array}$ & $\begin{array}{l}51.8 \\
48.5 \\
49.1 \\
48.5 \\
53.7 \\
51.8 \\
51.4 \\
50.5 \\
50.9\end{array}$ \\
\hline
\end{tabular}

Av.

April 14, 1916

\begin{tabular}{lllllllll}
$1-47$ & 0 & 53.83 & $1-49$ & 1 & 52.30 & $1-59$ & 1 & 47.89 \\
$1-33$ & 1 & 61.29 & $1-44$ & 0 & 55.38 & $1-55$ & 1 & 49.56 \\
$1-31$ & 3 & 61.23 & $1-42$ & 1 & 56.43 & $1-49$ & 0 & 52.84 \\
$1-36$ & 2 & 58.75 & $1-51$ & 0 & 51.89 & $1-48$ & 1 & 52.77 \\
$1-29$ & 2 & 63.37 & $1-50$ & 1 & 51.81 & $1-45$ & 0 & 54.85 \\
$1-34$ & 3 & 52.36 & $1-53$ & 0 & 50.97 & $1-53$ & 2 & 49.91 \\
$1-30$ & 1 & 63.33 & $1-46$ & 2 & 53.20 & $1-48$ & 3 & 51.66 \\
$1-34$ & 0 & 63.27 & $1-53$ & 1 & 50.44 & $1-59$ & 0 & 48.40 \\
$1-24$ & 0 & 68.57 & & & & & & \\
\hline
\end{tabular}

A $\mathbf{v}$

Apri1 15, 1916

$\begin{array}{lllllllll}1-36 & 1 & 59.37 & 1-46 & 0 & 54.33 & 1-52 & 3 & 49.82\end{array}$

$\begin{array}{lllllllll}1-33 & 0 & 61.93 & 1-51 & 0 & 51.89 & 1-50 & 0 & 52.36\end{array}$

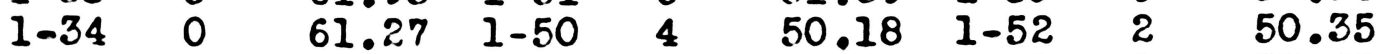

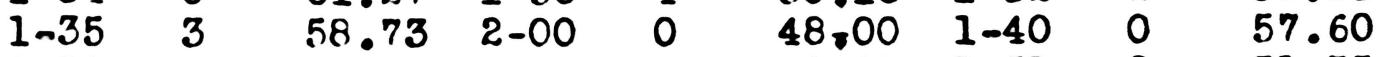

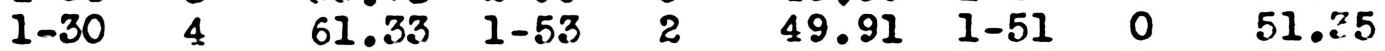

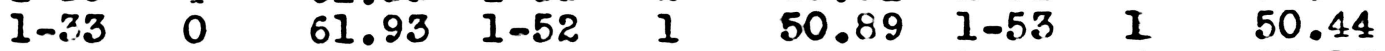

$\begin{array}{lllllllll}1-28 & 0 & 65.45 & 1-53 & 2 & 49.91 & 1-57 & 4 & 47.17\end{array}$

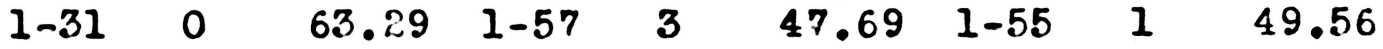

A v.

$1-.33 \quad 0 \quad 61.93$

A

Apri1 17. 1916

$\begin{array}{lllllllll}1-30 & 0 & 64.00 & 1-47 & 0 & 53.83 & 1-48 & 1 & 52.77 \\ 1-29 & 1 & 64.04 & 1-51 & 1 & 51.35 & 1-52 & 2 & 50.35 \\ 1-29 & 0 & 64.71 & 1-54 & 1 & 50.80 & 1-56 & 2 & 48.62 \\ 1-34 & 0 & 61.27 & 1-50 & 1 & 51.81 & 1-50 & 5 & 49.63 \\ 1-33 & 0 & 61.93 & 2-00 & 1 & 47.50 & 1-49 & 1 & 52.30 \\ 1-29 & 0 & 64.71 & 1-54 & 1 & 50.00 & 1-54 & 2 & 49.47 \\ 1-29 & 2 & 63.37 & 1-48 & 1 & 52.77 & 1-51 & 2 & 50.81 \\ 1-22 & 0 & 70.24 & 1-54 & 0 & 50.52 & 1-45 & 0 & 54.85 \\ 1-30 & 2 & 62.66 & & & & 1-45 & 1 & 54.28 \\ 1-31 & 0 & 63.29 & & & & & & \end{array}$


White Girls

lwg $2 \mathrm{wg} \quad 3$ wg

Time Exrors II.P.U.-Time Errors H.P.M.-Time Errors H.P.M. 133 April 18.1916

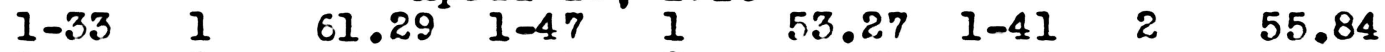

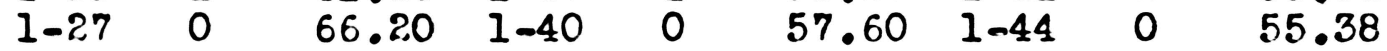

$\begin{array}{lllllllll}1-27 & 1 & 65.51 & 1-43 & 0 & 55.92 & 1-44 & 2 & 54.23\end{array}$

$\begin{array}{lllllllll}1-2.9 & 0 & 64.71 & 1-37 & 0 & 59.38 & 1-48 & 3 & 51.66\end{array}$

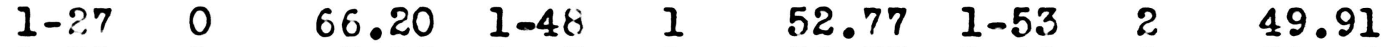

$\begin{array}{lllllllll}1-30 & 1 & 63.33 & 1-43 & 1 & 55.33 & 1-48 & 5 & 50.55\end{array}$

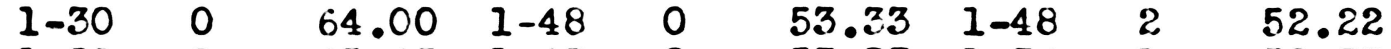

$\begin{array}{lllllllll}1-28 & 0 & 65.45 & 1-47 & 0 & 53.83 & 1-36 & 1 & 59.37\end{array}$

$\begin{array}{lllllllll}1-25 & 0 & 67.76 & 1-59 & 1 & 47.89 & 1-38 & 0 & 58.77\end{array}$

Av. $\begin{array}{lllllll}1-.7 & 1 & 65.51 & 1-44 & 2 & 54.23 \\ 64.99 & 54.36 & & \end{array}$

\begin{tabular}{|c|c|c|c|c|c|c|c|c|}
\hline $\begin{array}{l}1-26 \\
1-23 \\
1-23 \\
1-21 \\
1-21 \\
1-24 \\
1-27 \\
1-26 \\
1-26 \\
1-2 .\end{array}$ & $\begin{array}{l}0 \\
0 \\
0 \\
0 \\
1 \\
0 \\
1 \\
2 \\
1 \\
2\end{array}$ & $\begin{array}{l}\text { Ar } \\
66.97 \\
69.39 \\
69.39 \\
71.11 \\
70.37 \\
68.57 \\
65.51 \\
65.58 \\
66.27 \\
68.78\end{array}$ & $\begin{array}{l}111 \\
1-38 \\
1-28 \\
1-36 \\
1-36 \\
1-36 \\
1-39 \\
1-39 \\
1-31 \\
1-32\end{array}$ & $\begin{array}{l}7916 \\
0 \\
0 \\
1 \\
0 \\
0 \\
1 \\
1 \\
0 \\
5\end{array}$ & $\begin{array}{l}58.77 \\
65.45 \\
59.37 \\
60.00 \\
60.00 \\
57.54 \\
57.54 \\
63.29 \\
59.34\end{array}$ & $\begin{array}{l}1-36 \\
1-32 \\
1-33 \\
1-33 \\
1-44 \\
1-48 \\
1-38 \\
1-44 \\
1-34\end{array}$ & $\begin{array}{l}1 \\
3 \\
0 \\
0 \\
1 \\
2 \\
0 \\
2 \\
5\end{array}$ & $\begin{array}{l}59.37 \\
60.65 \\
61.93 \\
61.93 \\
54.80 \\
54.75 \\
58.77 \\
54.23 \\
58.08\end{array}$ \\
\hline
\end{tabular}

Negro Boys

$\mathrm{Ibb} \quad \mathrm{abb} \quad 3 \mathrm{bb}$

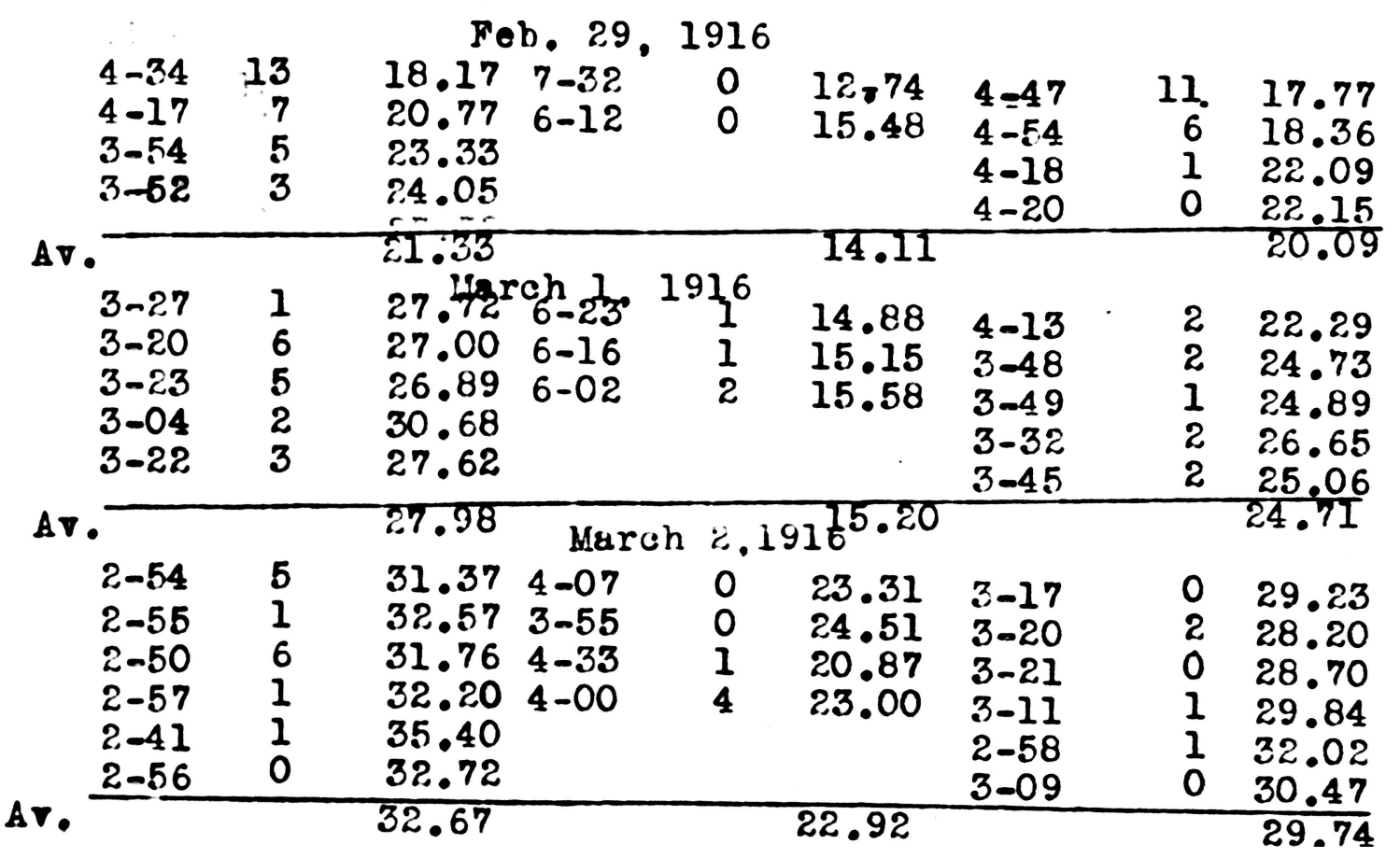


$1 \mathrm{bb}$

$2 b b$

$3 \mathrm{bb}$

Time Errors II.P.H.-Time Errors H.P.H.-Time Errors H.P.H. 2 llarch 3,1916

$\begin{array}{lllllllll}2-43 & 0 & 35.33 & 4-00 & 0 & 24.00 & 3-14 & 1 & 29.38\end{array}$

$\begin{array}{lllllllll}2-45 & 4 & 33.45 & 4-05 & 2 & 23.00 & 3-02 & 0 & 31.64\end{array}$

$\begin{array}{lllllllll}2-37 & 4 & 35.15 & 4-00 & 0 & 24.00 & 3-03 & 1 & 31.14\end{array}$

$\begin{array}{lllllllll}2-46 & 3 & 33.69 & 4-09 & 0 & 23.30 & 2-50 & 0 & 33.88\end{array}$

$\begin{array}{lllllllll}2-29 & 3 & 37.45 & 3-36 & 0 & 2.6 .66 & 2-47 & 2 & 33.17\end{array}$

$\begin{array}{llllll}2-29 & 6 & 36.24 & 2-34 & 1 & 37.01\end{array}$

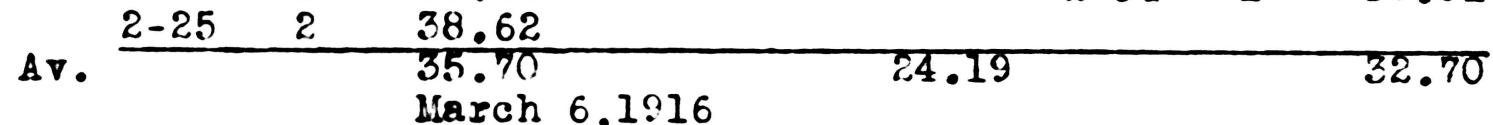

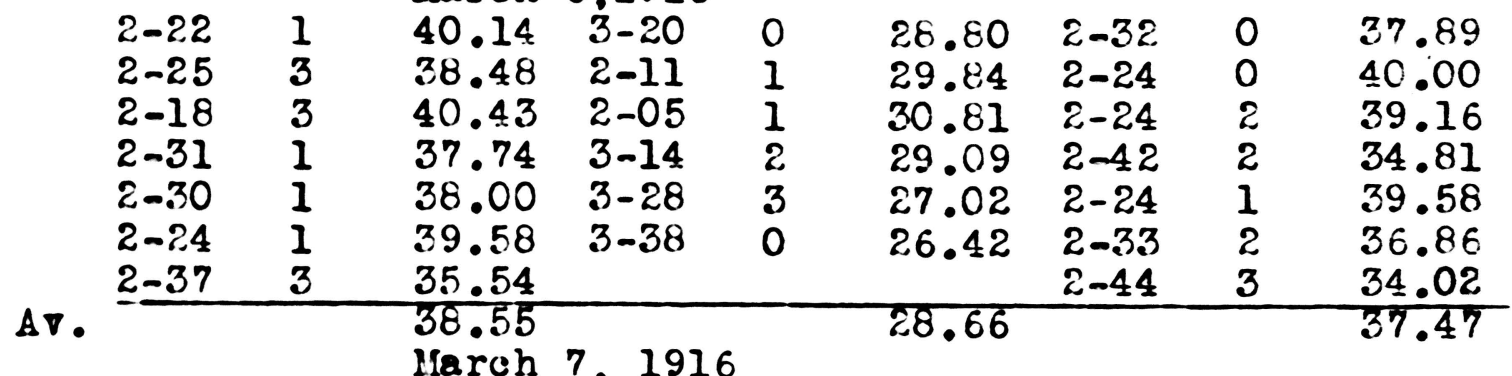

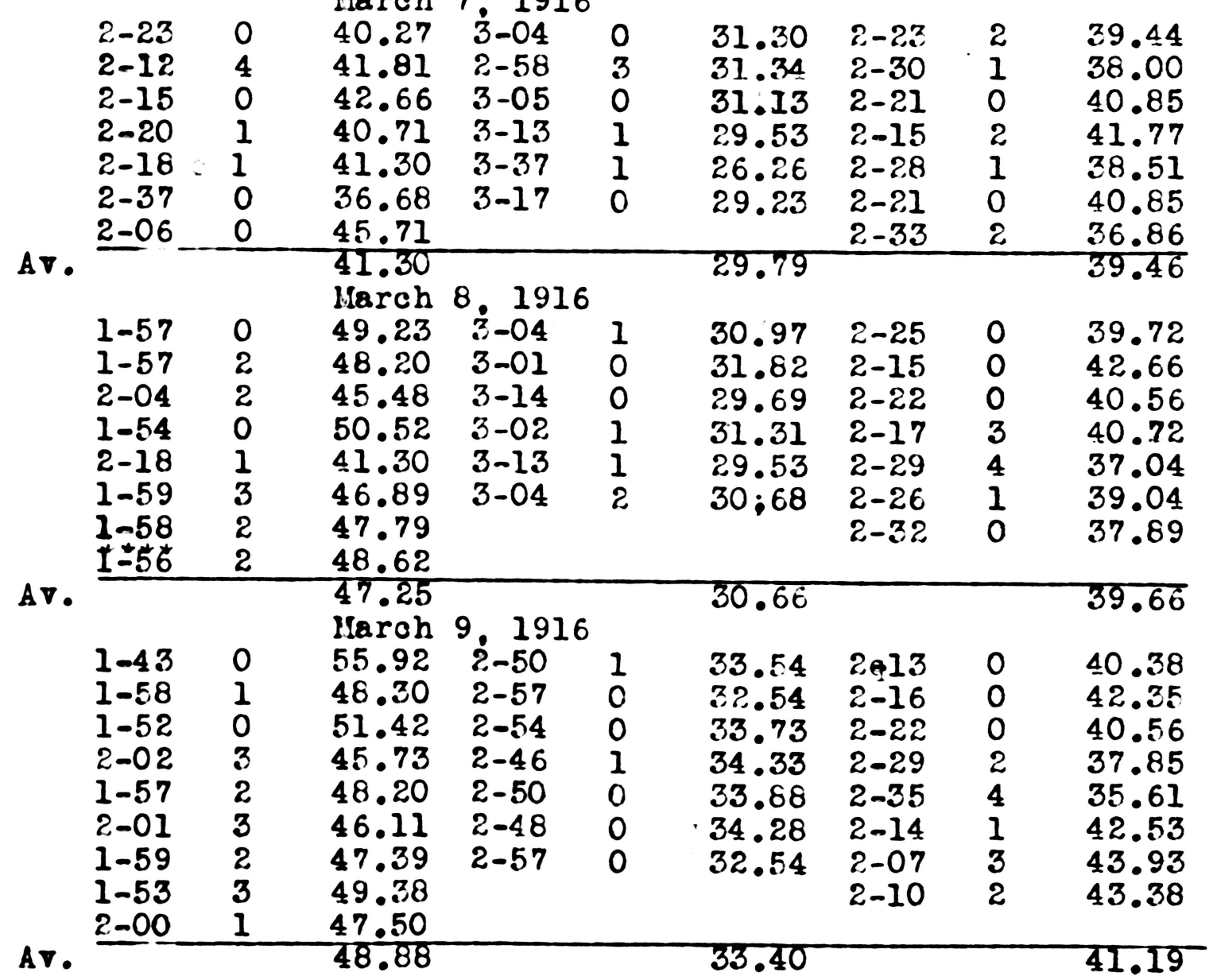


$1 \mathrm{bb}$

$2 \mathrm{bb}$

$3 \mathrm{bb}$

Time Errorg I..P.M.-Time Errors M.P.:..-Time Errors H.P.U. March 10,1916

$\begin{array}{lllllllll}1-53 & 1 & 50.44 & 2-50 & 4 & 32.82 & 2-13 & 2 & 42.42 \\ 1-59 & 1 & 47.89 & 2-41 & 1 & 35.40 & 1-54 & 0 & 50.52 \\ 1-53 & 3 & 49.38 & 2-48 & 1 & 33.92 & 1-54 & 1 & 50.00 \\ 2-00 & 1 & 47.50 & 2-48 & 1 & 33.92 & 2-01 & 2 & 46.61 \\ 2-00 & 4 & 46.00 & 3-09 & 1 & 30.15 & 1-56 & 3 & 48.10 \\ 2-00 & 0 & 48.00 & 2-39 & 0 & 36.22 & 1-56 & 2 & 48.62 \\ 1-44 & 1 & 54.80 & 2-47 & 2 & 33.17 & 2-06 & 0 & 45.71 \\ 1-50 & 3 & 50.72 & & & & 1-56 & 2 & 48.62\end{array}$

A .

49.30 Haren $1: .1916$

$\begin{array}{lllllllll}1-51 & 2 & 50.81 & 3-01 & 1 & 31.49 & 2-07 & 0 & 45.35\end{array}$

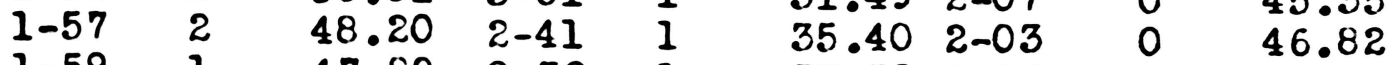

$\begin{array}{lllllllll}1-59 & 1 & 47.89 & 2.32 & 1 & 37.50 & 2-03 & 0 & 46.82\end{array}$

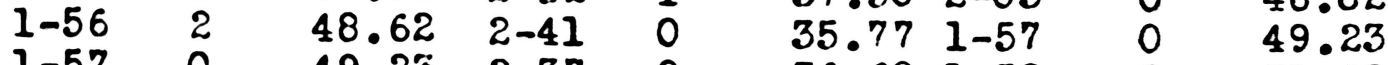

$\begin{array}{lllllllll}1-57 & 0 & 49.25 & 2-37 & 0 & 36.68 & 1-52 & 0 & 51.42 \\ 2-04 & 1 & 45.96 & 2-44 & 0 & 35.12 & 2-00 & 1 & 47.50\end{array}$

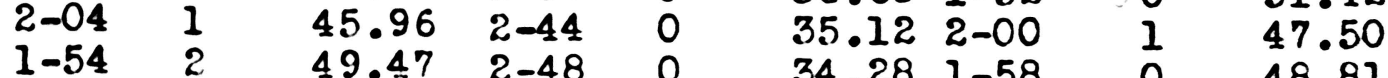

$\begin{array}{lllllllll}1-56 & 2 & 49.47 & 2-48 & 0 & 34.28 & 1-58 & 0 & 48.81\end{array}$

Av. $48.60 \quad 35.17 \quad 17 \quad 1 \quad 49.56$

$\begin{array}{lllllll}2-01 & 0 & 47.60^{\mathrm{I}_{2} \mathrm{CR}_{8} 14} \mathrm{~T}^{1916} 33.92 & 2-01 & 1 & 47.10\end{array}$

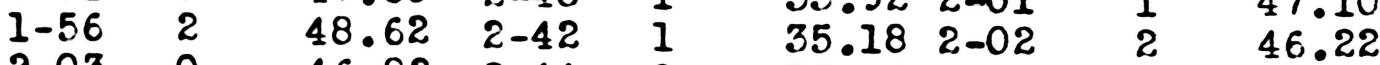

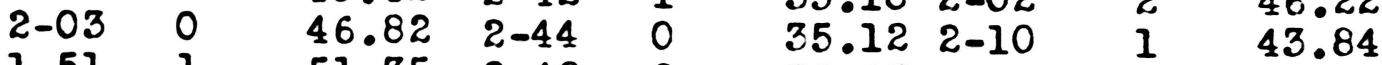

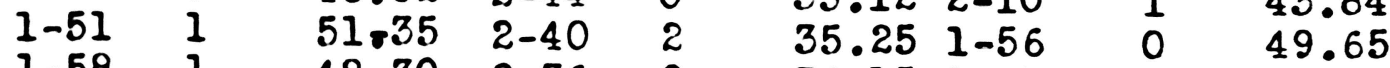

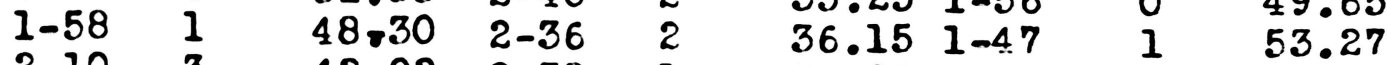

$\begin{array}{lllllllll}2-10 & 3 & 42.92 & 2-38 & 1 & 36.07 & 1-50 & 1 & 51.81\end{array}$

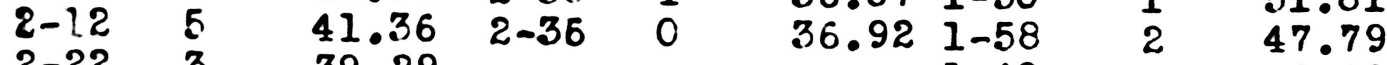

$\begin{array}{rrrrrr}2-22 & 3 & 39.29 & 1-48 & 2 & 52.22\end{array}$

Av.

$\begin{array}{lllllllll}1-49 & 0 & 47.60 & 2-35 & 1 & 36.77 & 2-09 & 1 & 44.18\end{array}$

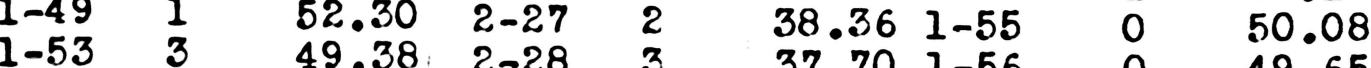

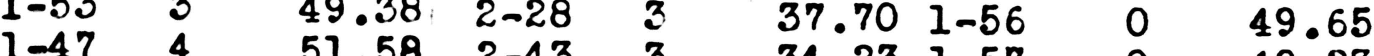

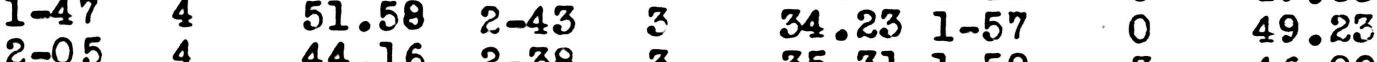

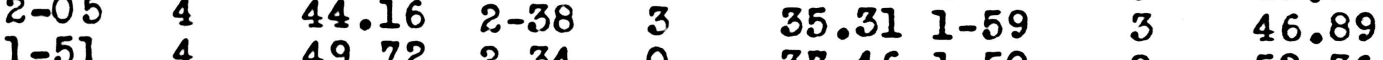

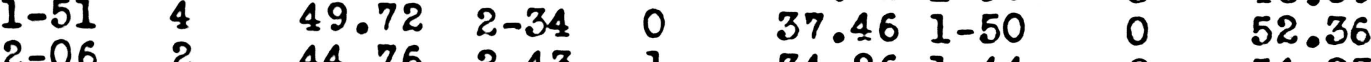

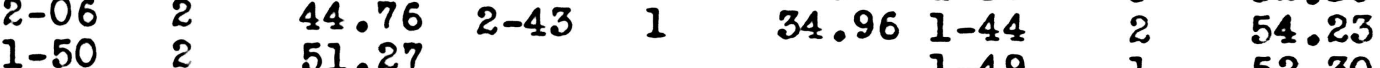

$51.27 \quad 1-49 \quad 1 \quad 52.30$

A $\mathbf{v}$

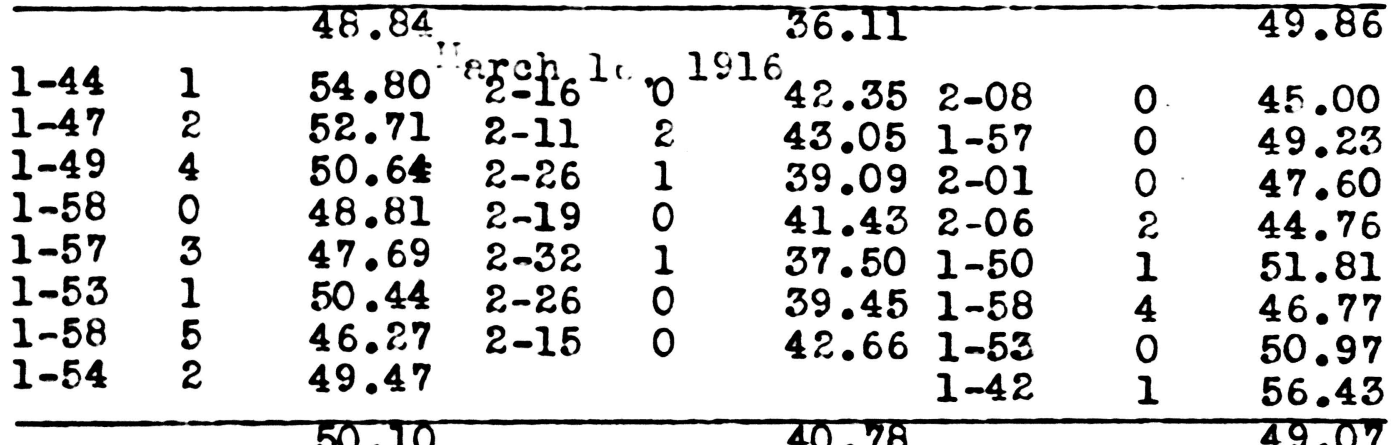

A $\boldsymbol{\nabla}$.

50.10

40.78 
$\mathrm{Ibb}$

$2 \mathrm{bb}$

$3 \mathrm{bb}$

Time Errors U.P.H.-Time Frrors II.P.?.-Time Errors H.P.M. Iarch 17, 1916

$\begin{array}{lllllllll}1-49 & 1 & 52.30 & 2-14 & 3 & 40.43 & 1-53 & 0 & 50.97 \\ 1-50 & 1 & 51.81 & 2-18 & 0 & 41.73 & 1-55 & 3 & 48.52 \\ 1-54 & 1 & 50.00 & 2-21 & 0 & 40.85 & 1-48 & 3 & 51.66 \\ 1-51 & 2 & 50.81 & 2-18 & 0 & 41.73 & 1-46 & 2 & 53.20 \\ 1-50 & 1 & 51.81 & 2-16 & 0 & 42.35 & 1-51 & 2 & 50.81 \\ 1-47 & 3 & 52.14 & 2-17 & 0 & 42.55 & 2-01 & 2 & 46.61 \\ 1-44 & 1 & 54.80 & 2-18 & 0 & 41.73 & 1-48 & 0 & 53.33 \\ 1-52 & 1 & 50.89 & & & & 1-50 & 1 & 51.81\end{array}$

Av. 51.82 Ior. 20, 19K/1.62 50.86

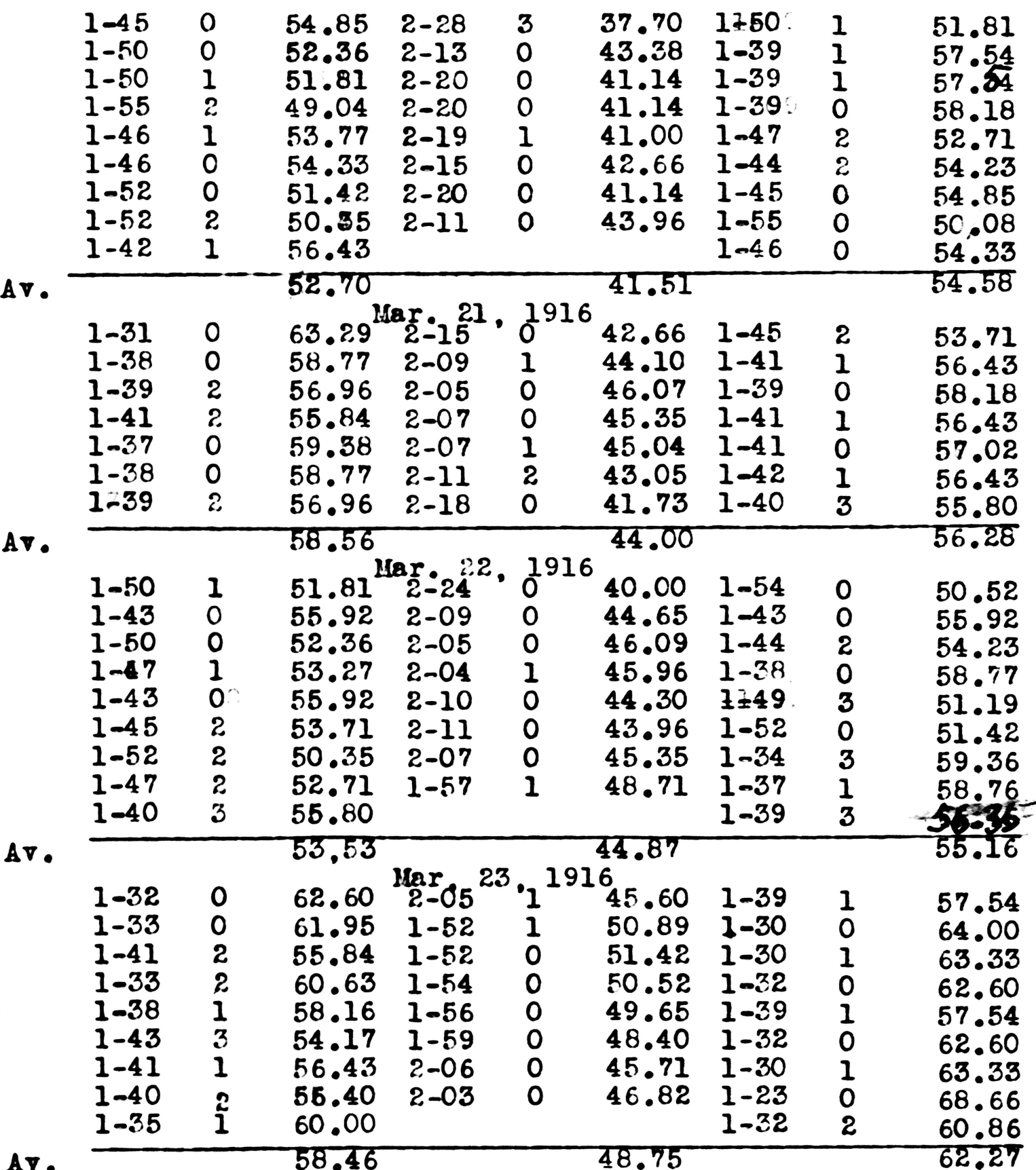


$1 \mathrm{bb}$

$2 \mathrm{bb}$

$3 \mathrm{bb}$

T1me Errors H.P.M.-Time Errors H.P.H.-Time Errors H.P.H. Laroh 24, 1916.

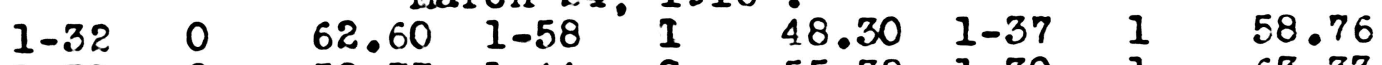

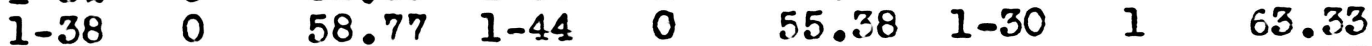

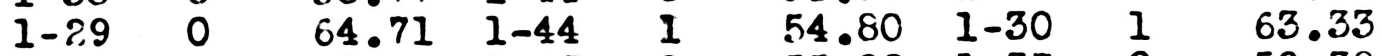

$\begin{array}{lllllllll}1-35 & 0 & 60.63 & 1-43 & 0 & 55.92 & 1-37 & 0 & 59.38\end{array}$

$\begin{array}{lllllllll}1-40 & 0 & 57.60 & 1-45 & 0 & 54.82 & 1-38 & 3 & 56.93\end{array}$

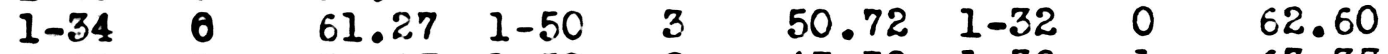

$\begin{array}{lllllllll}1-41 & 1 & 56.43 & 1-58 & 2 & 47.79 & 1-30 & 1 & 63.33\end{array}$

$\begin{array}{lllllllll}1-34 & 0 & 61.27 & 1-46 & 0 & 54.33 & 1-30 & 0 & 64.00\end{array}$

Av.

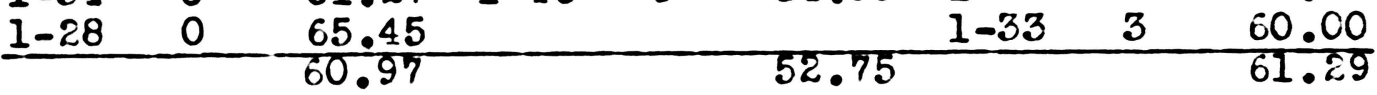

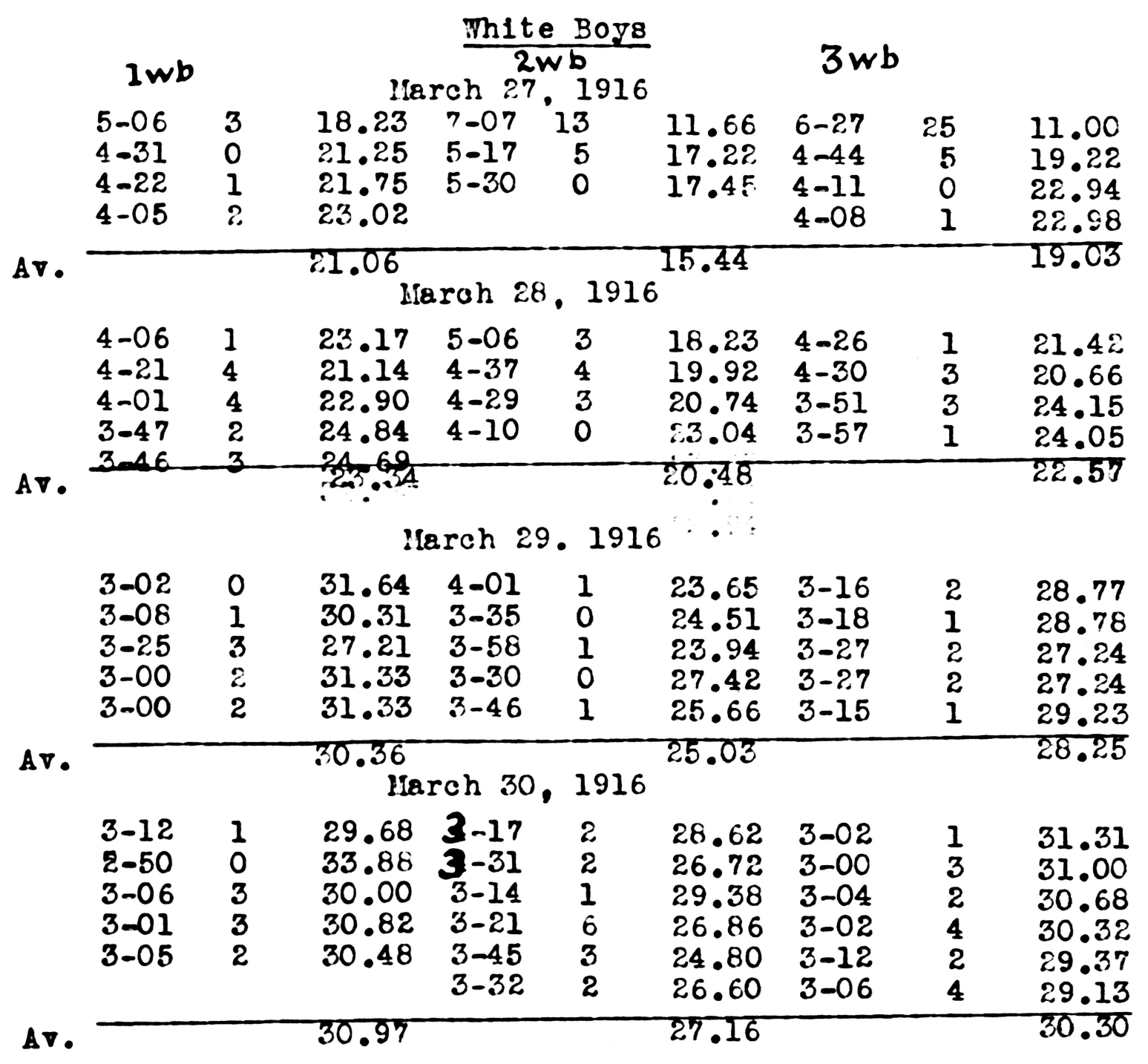


White Boys

79

$1 w b$

$2 w \mathrm{~h}$

$3 \mathrm{wb}$

Time Errory 11.P.II.-Time Errors H.P.I.-Time Errors M.

$\begin{array}{lllllllll}3-03 & 3 & 30.49 & 2-48 & 1 & 33.92 & 2-58 & 4 & 31.01 \\ 2-45 & 2 & 34.18 & 3-10 & 0 & 30.31 & 2-45 & 1 & 34.54\end{array}$

$\begin{array}{lllllllll}2-37 & 4 & 35.15 & 2-50 & 0 & 30.31 & 2-45 & 1 & 34.54\end{array}$

$\begin{array}{lllllllll}2-39 & 1 & 35.84 & 3-05 & 6 & 33.8 .8 & 2-40 & 0 & 36.00\end{array}$

$\begin{array}{lllllllll}2-49 & 1 & 33.72 & 3-18 & 4 & 29.18 & 2-43 & 1 & 34.96\end{array}$

$\begin{array}{lllllllll}2-55 & 2 & 32.22 & 3-04 & 1 & 27.87 & 2-41 & 3 & 34.65 \\ 2-44 & 0 & 35.12 & & & 30.97 & 3-06 & 5 & 29.35\end{array}$

Av. $33.8131 .02 \quad 33.09$

$2-27 \quad$ April 3, 1916

$\begin{array}{lllllllll}2-23 & 1 & 38.77 & 3-03 & 2 & 30.87 & 2-40 & 3 & 34.08\end{array}$

$\begin{array}{lllllllll}2-31 & 0 & 38.14 & 3-08 & 2 & 31.68 & 2-32 & 1 & 37.50\end{array}$

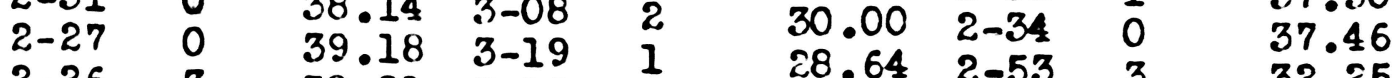

$\begin{array}{lllllllll}2-26 & 3 & 38.21 & 3-18 & 1 & 28.64 & 2-53 & 3 & 32.25\end{array}$

$\begin{array}{lllllllll}2-41 & 4 & 34.28 & 3-26 & 3 & 28.78 & 2-47 & 1 & 34.13\end{array}$

$\begin{array}{lllllll}2-35 & 1 & 36.77 & 27.08 & 2-50 & 1 & 33.54 \\ \end{array}$

Av. $37.9429 .50-34.25$

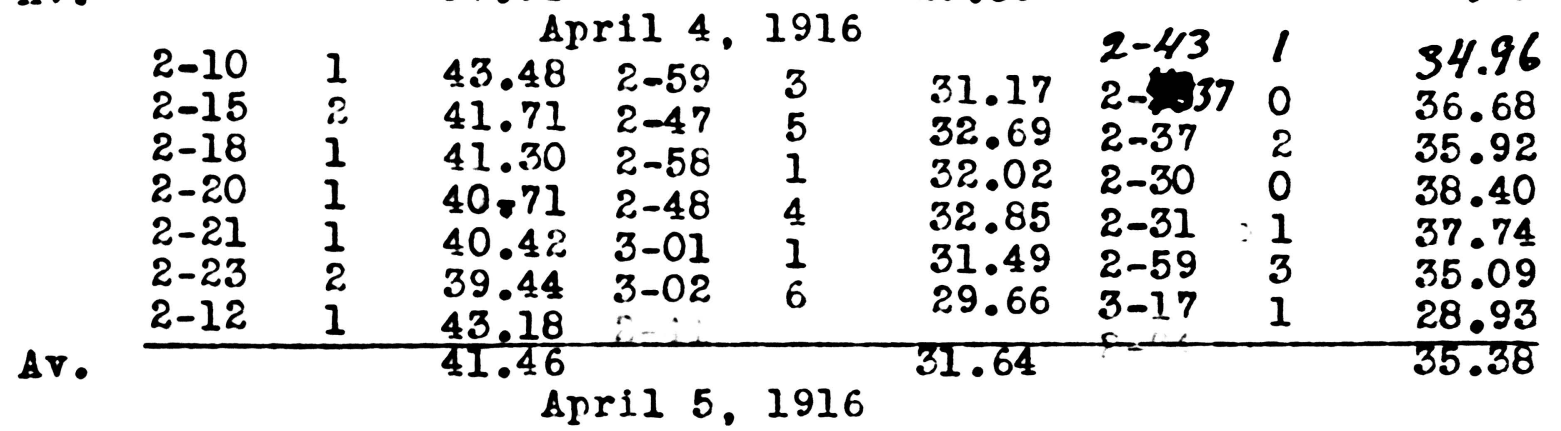

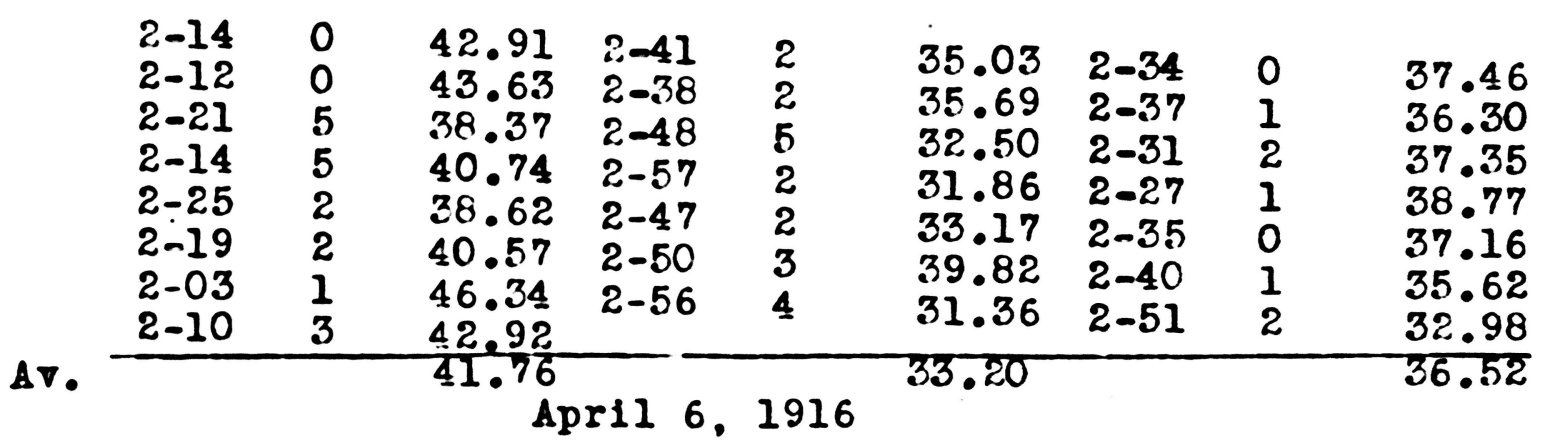

\begin{tabular}{|c|c|c|c|c|c|c|c|c|}
\hline $\begin{array}{l}2-17 \\
2-06 \\
2-18 \\
2-12 \\
2-11 \\
2-02 \\
2-06 \\
2-00\end{array}$ & $\begin{array}{l}1 \\
1 \\
1 \\
8 \\
3 \\
1 \\
1 \\
3\end{array}$ & $\begin{array}{l}41.60 \\
45.23 \\
41.30 \\
42.72 \\
42.59 \\
46.72 \\
45.23 \\
46.50\end{array}$ & $\begin{array}{l}2-16 \\
2-11 \\
2-10 \\
2-14 \\
2-07 \\
2-14 \\
2-2.3\end{array}$ & $\begin{array}{l}1 \\
3 \\
2 \\
1 \\
0 \\
3 \\
0\end{array}$ & $\begin{array}{r}41.91 \\
42.59 \\
43.38 \\
42.53 \\
45.35 \\
41.64 \\
40.27\end{array}$ & $\begin{array}{l}2-34 \\
2-37 \\
2-35 \\
2-40 \\
2-25 \\
2-24 \\
2-13\end{array}$ & $\begin{array}{l}1 \\
1 \\
2 \\
1 \\
2 \\
2 \\
1\end{array}$ & $\begin{array}{l}37.01 \\
36.30 \\
36.38 \\
35.62 \\
38.62 \\
39.16 \\
42.85\end{array}$ \\
\hline
\end{tabular}


White Boys

Iwb

$2 w b$

$3 w b$

Time Errors H.P.H.-Time Errors H.P.H.-Time Errors H.P.II. April 7. 1916

$\begin{array}{lllllllll}2-14 & 1 & 42.53 & 2-26 & 6 & 36.98 & 2-22 & 1 & 40.14\end{array}$

$\begin{array}{lllllllll}2-05 & 1 & 45.60 & 2-30 & 1 & 38.00 & 2-26 & 1 & 39.04\end{array}$

$\begin{array}{lllllllll}2-03 & 3 & 45.36 & 2-32 & 4 & 36.31 & 2-17 & 0 & 42.55\end{array}$

$\begin{array}{lllllllll}2-06 & 2 & 44.76 & 2-23 & 1 & 39.86 & 2-07 & 1 & 45.98\end{array}$

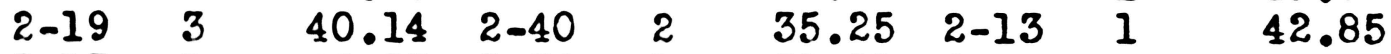

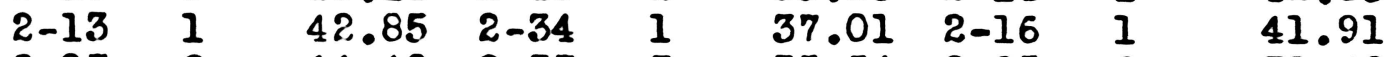

$\begin{array}{lllllllll}2-07 & 2 & 44.40 & 2-37 & 3 & 35.54 & 2-25 & 2 & 38.62\end{array}$

A $\boldsymbol{\nabla}$. $1-590 \quad 48.40$ ?

44.28

April 10, 1916

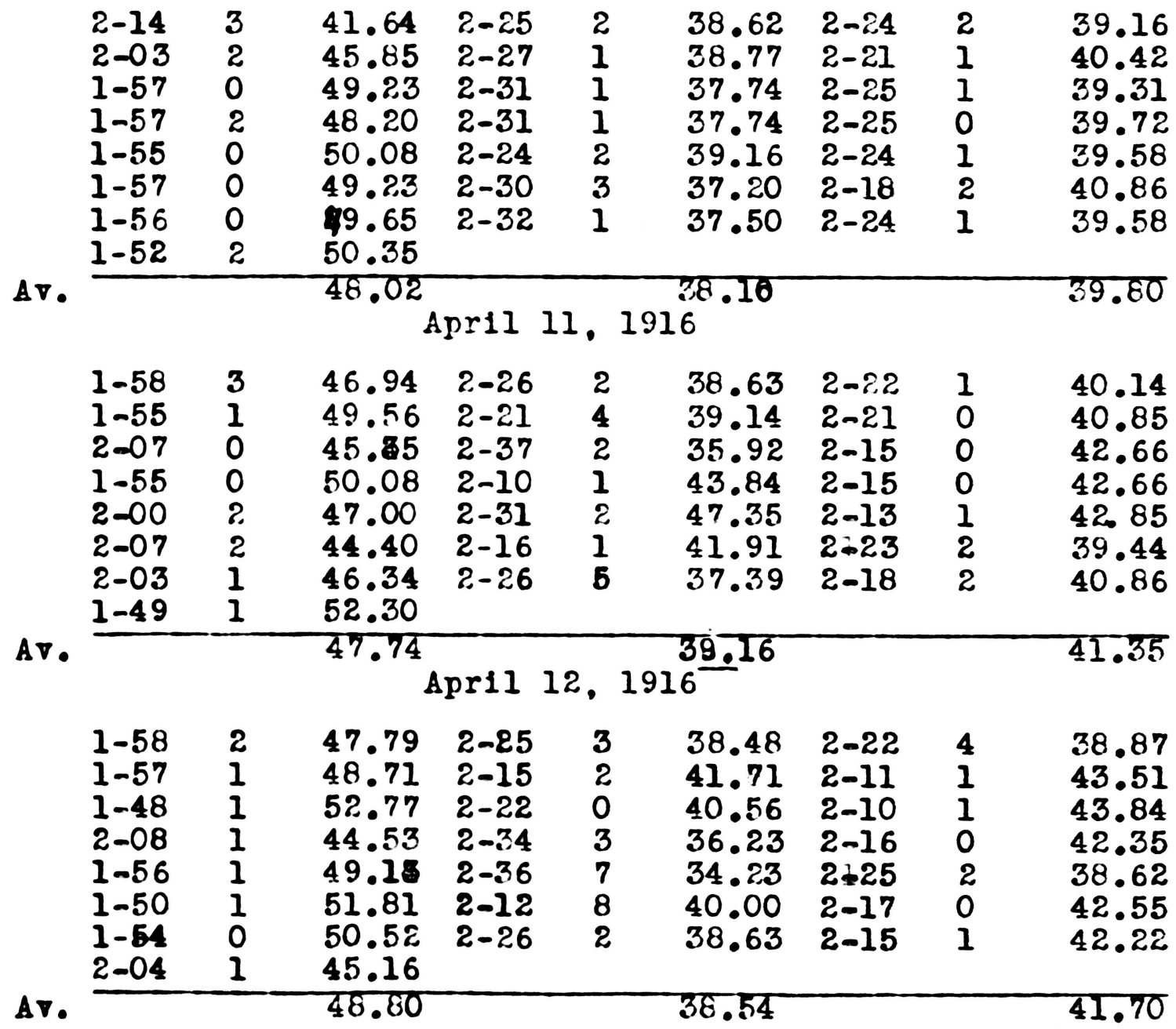


$1 \mathrm{wb}$

$2 \nabla b$

$3 \mathrm{wb}$

Time Errorg H.P.If.-Tlme Errors H.P.H.-Time Frrors I.P.II. April 13,1916

$\begin{array}{lllllllll}1-56 & 1 & 49.13 & 2-25 & 2 & 38.62 & 2-14 & 1 & 42.53 \\ 1-58 & 1 & 46.30 & 2-17 & 2 & 41.16 & 2-11 & 1 & 43.51\end{array}$

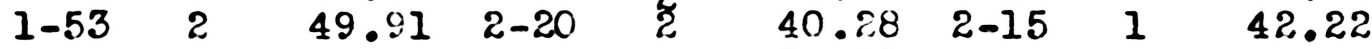

$\begin{array}{lllllllll}1-48 & 0 & 53.33 & 2-40 & 4 & 34.50 & 2-19 & 1 & 41.00\end{array}$

$\begin{array}{lllllllll}1-50 & 0 & 52.36 & 2-30 & 4 & 36.80 & 2-19 & 2 & 40.57\end{array}$

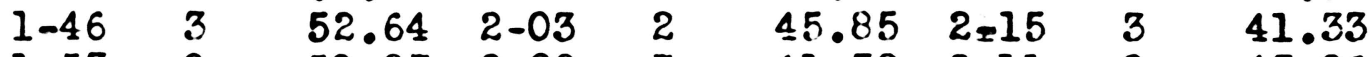

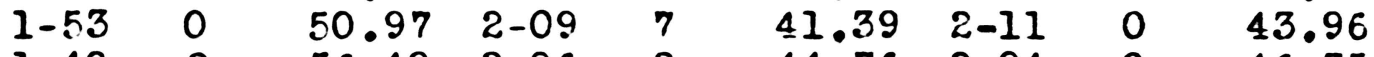

$\begin{array}{lllllllll}1-40 & 2 & 56.40 & 2-06 & 2 & 44.76 & 2-04 & 0 & 46.35 \\ 1-43 & 0 & 55.92 & 2 & & & & & \end{array}$

A .

$\frac{1-430}{52.10}$

.40 .42

42.68

$\begin{array}{lll}1-48 & 0 & 53.33^{\mathrm{ril} 14} \\ 1-39 & 1 & 5916\end{array}$

$\begin{array}{lllllllll}1-41 & 0 & 57.02 & 1-49 & 1 & 42.30 & 2-07 & 1 & 45.04\end{array}$

$\begin{array}{lllllllll}1-42 & 0 & 56.47 & 1-54 & 7 & 46.84 & 2-05 & 1 & 45.60\end{array}$

$\begin{array}{lllllllll}1-49 & 0 & 52.84 & 1-53 & 4 & 48.85 & 2-05 & 0 & 46.07\end{array}$

$\begin{array}{lllllllll}1-49 & 0 & 52.84 & 1-49 & 2 & 51.74 & 2-22 & 0 & 40.56\end{array}$

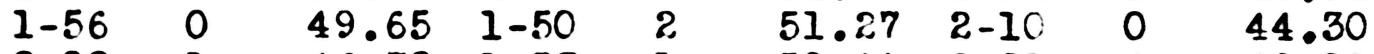

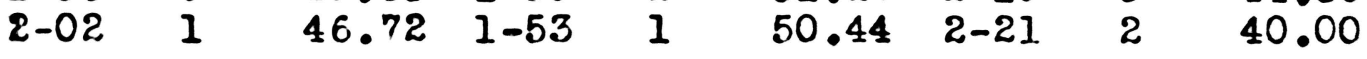

A

April 15, 1916

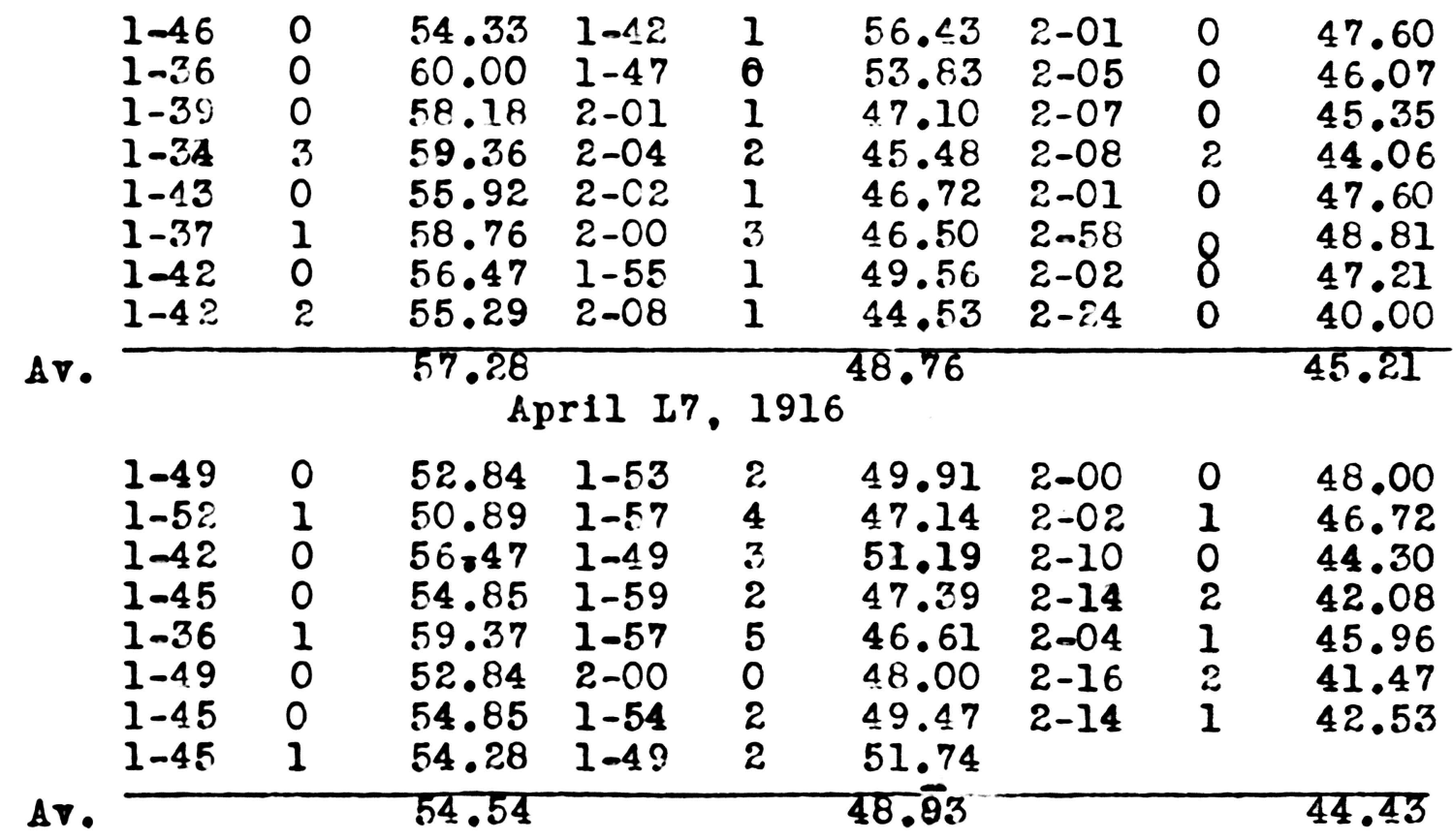


$1 w b$

$2 \pi \mathrm{b}$

$3 \pi \mathrm{b}$

Time Errors M.P.Il.-Time Errors M.P.I!.-Time Errors M.P.II. $1-36 \quad 0 \quad 60.0$ April 18, 1916

\begin{tabular}{lllllllll}
$1-36$ & 0 & 60.00 & $2-02$ & 0 & 47.21 & $2-03$ & 2 & 45.85 \\
$1-43$ & 0 & 55.92 & $2-00$ & 1 & 47.50 & $2-02$ & 0 & 47.21 \\
$1-40$ & 0 & 57.60 & $2-01$ & 4 & 45.61 & $2-11$ & 1 & 43.51 \\
$1-51$ & 0 & 51.35 & $2-00$ & 1 & 47.50 & $2-00$ & 1 & 47.50 \\
$1-41$ & 1 & 56.43 & $1-59$ & 3 & 46.89 & $2-21$ & 2 & 40.00 \\
$1-40$ & 0 & 57.60 & $2-04$ & 2 & 45.48 & $1-59$ & 1 & 47.89 \\
$1-40$ & 0 & 57.60 & $2-00$ & 3 & 46.50 & $2-11$ & 2 & 43.05 \\
$1-42$ & 0 & 56.47 & $1-52$ & 2 & 50.35 & $2-18$ & 1 & 41.30 \\
$1-4 ?$ & 3 & 54.70 & & & & & & \\
\hline
\end{tabular}

Av.

April 19, 1916

\begin{tabular}{|c|c|c|c|c|c|c|c|c|}
\hline $\begin{array}{l}1-55 \\
1-41 \\
1-40 \\
1-37 \\
1-31 \\
1-31 \\
1-42 \\
1-31 \\
1-42 \\
1-38\end{array}$ & $\begin{array}{l}2 \\
0 \\
0 \\
1 \\
1 \\
2 \\
0 \\
1 \\
0 \\
0\end{array}$ & $\begin{array}{l}49.04 \\
57.02 \\
57.60 \\
58.76 \\
62.63 \\
61.97 \\
56.47 \\
62.63 \\
56.47 \\
48.77\end{array}$ & $\begin{array}{l}1-53 \\
1-48 \\
1-34 \\
1-40 \\
1-44 \\
1-44 \\
1-41 \\
1-40 \\
1-47\end{array}$ & $\begin{array}{l}2 \\
2 \\
2 \\
1 \\
1 \\
2 \\
3 \\
3 \\
6 \\
3\end{array}$ & $\begin{array}{l}49.91 \\
55.29 \\
60.63 \\
57.00 \\
54.23 \\
55.65 \\
55.24 \\
54.00 \\
52.14\end{array}$ & $\begin{array}{l}1-55 \\
1-55 \\
2-01 \\
2-04 \\
1-58 \\
1-59 \\
2-04 \\
2-11\end{array}$ & $\begin{array}{l}0 \\
1 \\
0 \\
0 \\
1 \\
0 \\
1 \\
3\end{array}$ & $\begin{array}{l}50.08 \\
49.56 \\
47.10 \\
46.35 \\
48.30 \\
48.40 \\
45.96 \\
42.59\end{array}$ \\
\hline
\end{tabular}

M.P.II.-marbles correctly placed per minute 
UNIVERSITY OF MISSOURI

Columbus

MAY 181916

Dean Walter Miller:

Dear Cire:

$\checkmark$ have examined the thesis summits by Miss Orrea Maltier for the degree of Master of As to and approve it for this degree.

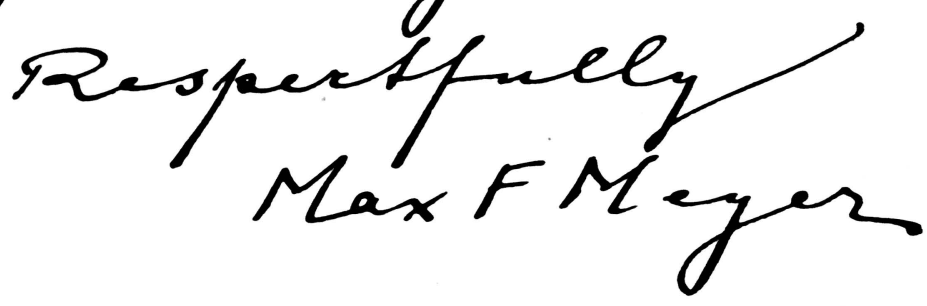




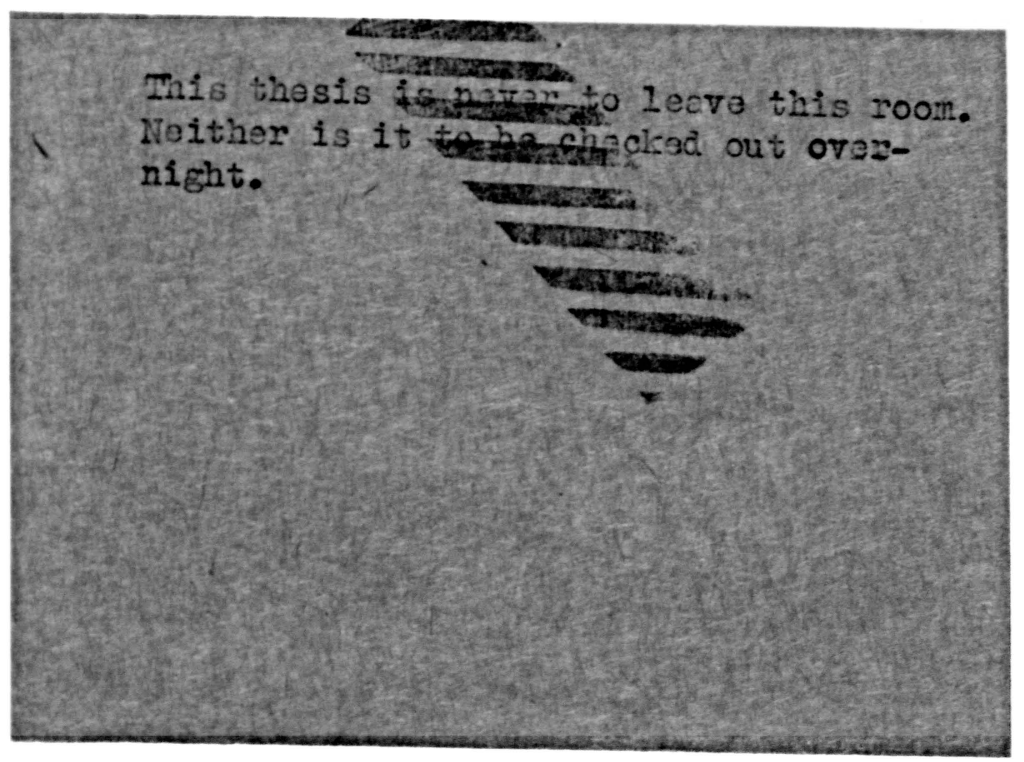


MU Libraries

Wal tner 19165 pecsheet. $t x t$

University of Mi ssouri-.-Col umbia

MU Theses and Dissertations (Pre-1920)

Local identifier

Capture information

Date captured

Scanner manufacturer

Scanner model

Scanning system software

Optical resolution

Color settings

File types

Source information

For mat

Content type

Source I D

Notes
Wal t ner 1916

\section{1}

Zeutschel

OS 15000

Omniscan v.12.4 SR4 (1947) 64-bit

$600 \mathrm{dpi}$

grayscale, 8 bit and color, 24 bit

B o ok

Text [with graphs and illustration]

$010-300140782$

Pages typed and single-sided.

Title page has signature and perforated

property stamp.

Cal number written on table of contents.

Some pages have handwritten margi nalia

and corrections.

Some pages have handwritten corrections

or erased text.

Text on page 24 is cut off on bottom. Last line

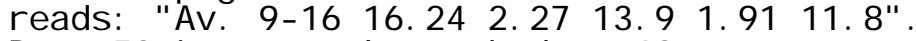

Page 59 incorrectly marked as 69.

Ink property stamp on actual page 69.

Ink property stamp on page 79.

Derivatives - Access copy

Compression

Editing soft ware

Resolution

Color

File types

Notes

Tiff compressed with LZW before conversion to $p d f$ Adobe Photoshop CS5

$600 \mathrm{dpi}$

Grayscale and color

$p d f$

Grayscale pages cropped, canvassed,

and i mages brightened.

Color pages cropped.

BI ank pages removed. 